イギリス慧法學における法制史的研究への要請

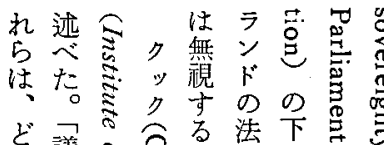

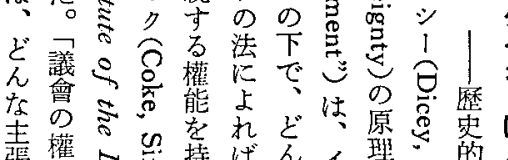

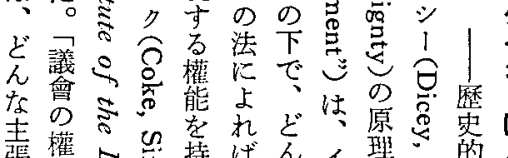

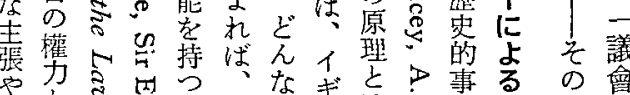

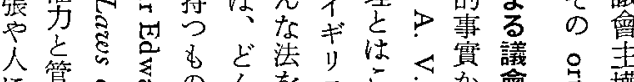

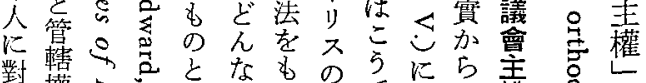

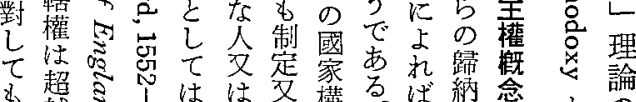

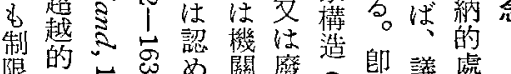

限县灾导

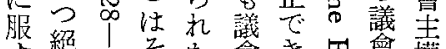

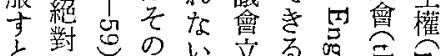

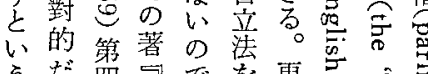

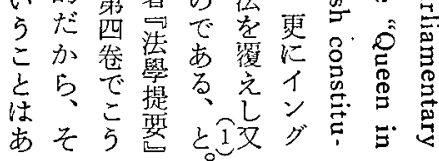

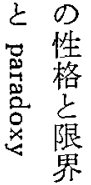

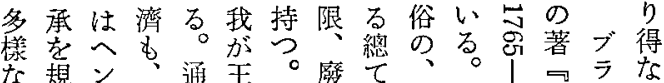

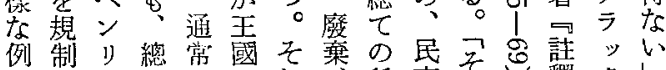

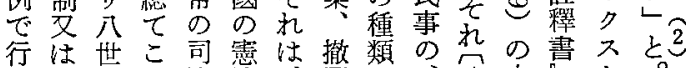

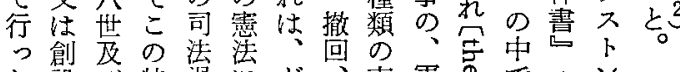

た設び特酮にど、事軍のでるン

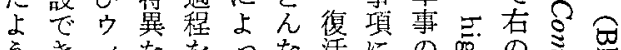

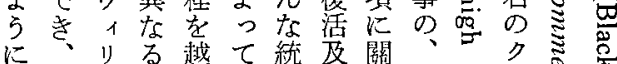

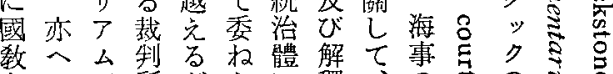

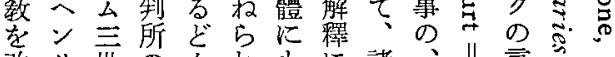

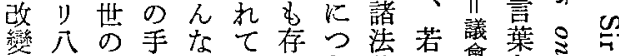

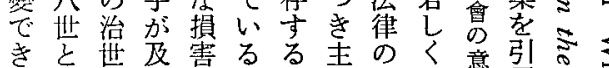

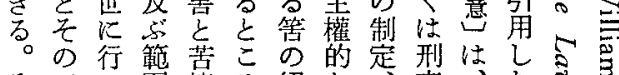

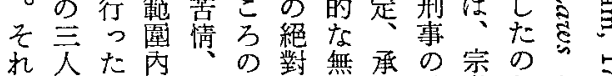

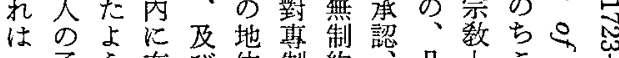

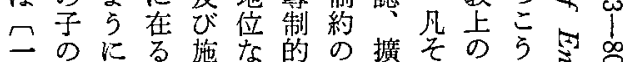

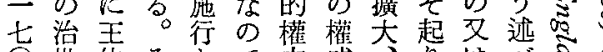

世世位そとで售威方は心

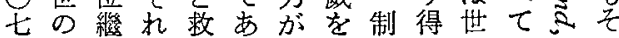

東 
選學賦郎あ政てる及位例會を憚に性自の年

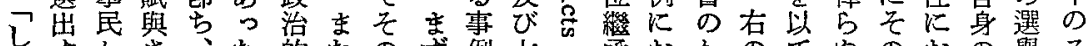

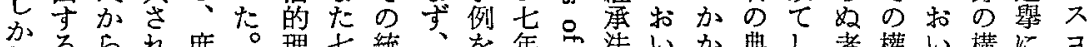

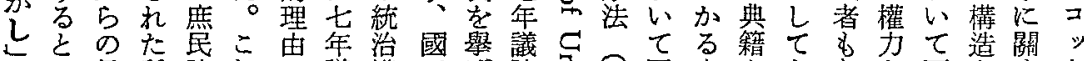

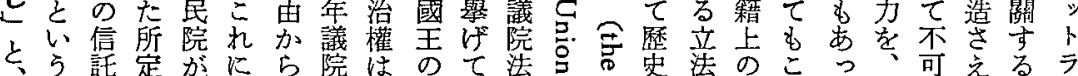

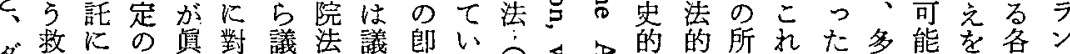

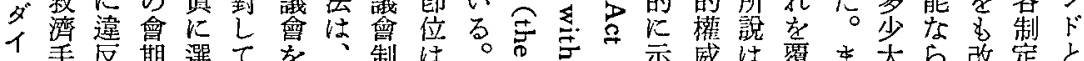
シ手反期選てを、制は。亚威は覆ま大ら改定と

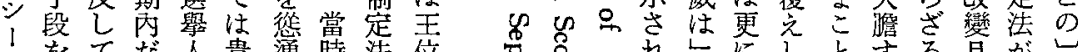

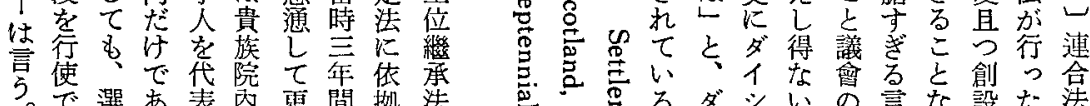

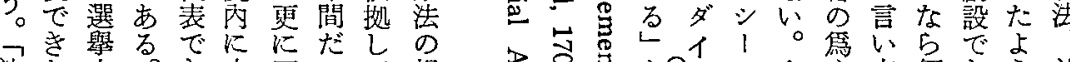

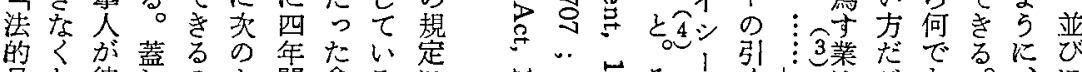

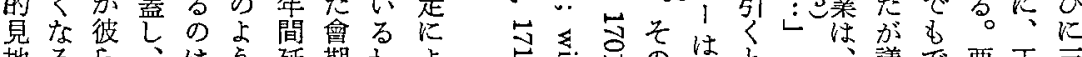

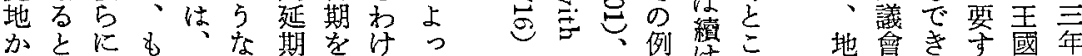

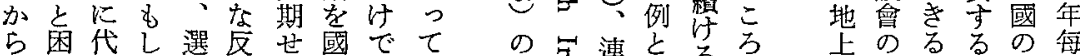

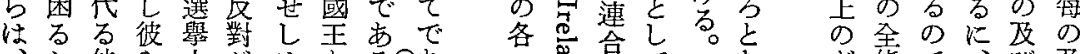

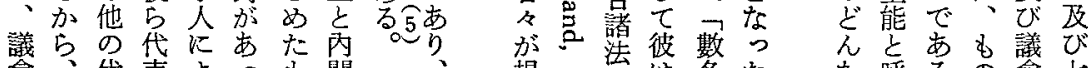

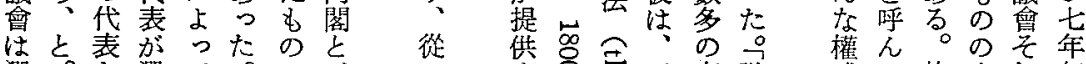

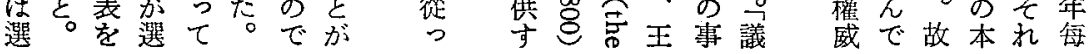

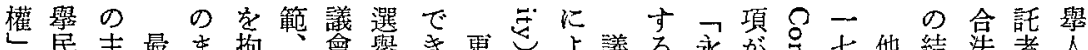

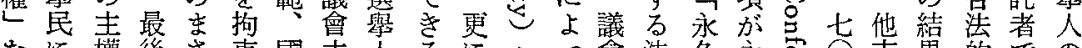

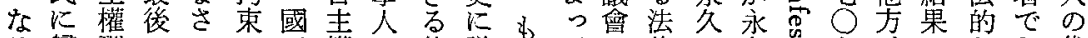
る歸理ににで王權の他議可ては律に久点志芯な゙な代 語屬諭名碟き大へ何の會能いこをとにす年連あ圭い理 をす、イな權の犯立声と称有と連。法合る權こ人 法るとシのい法当法權なばほ效い合品は諸と的とで

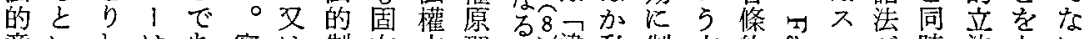

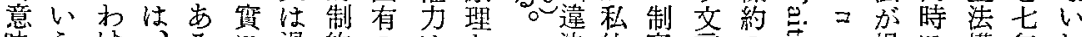

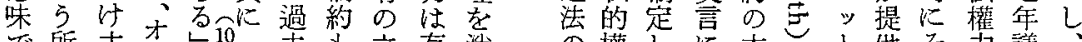

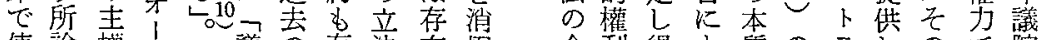

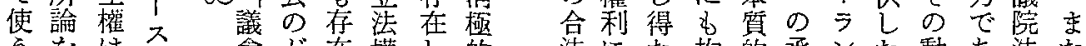

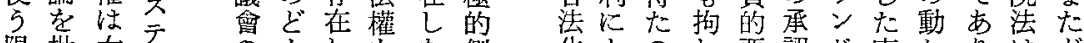

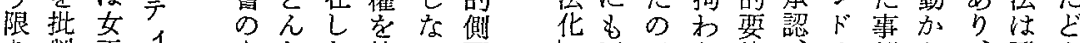

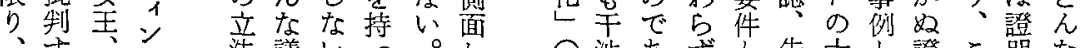

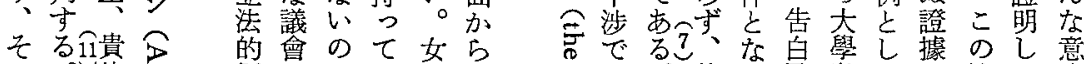

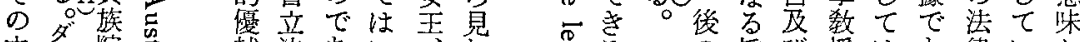

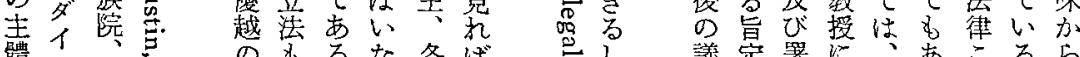

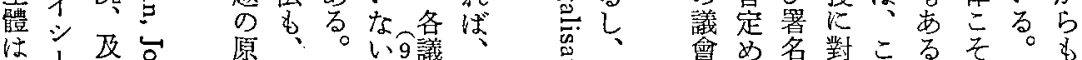

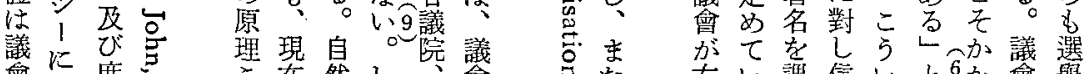

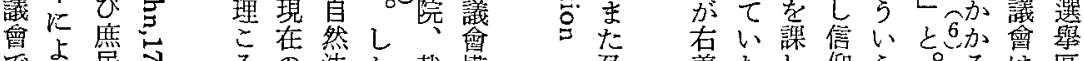

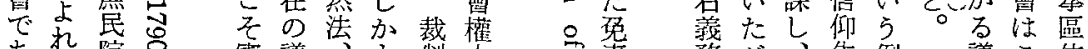

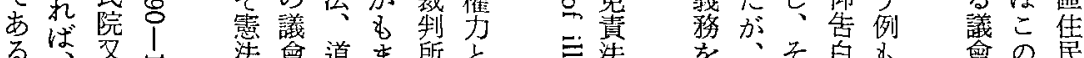

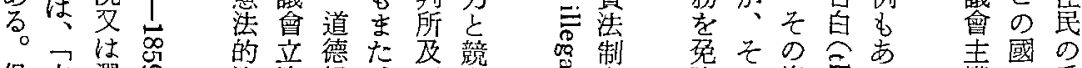

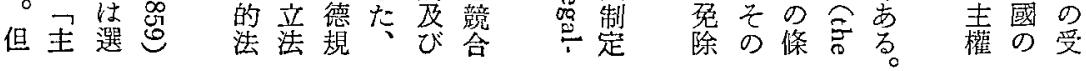


絕はユが 法いり立よ說奉名

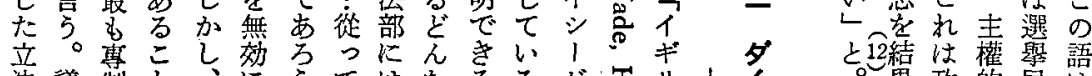

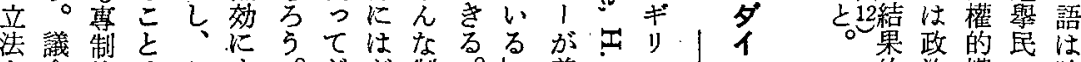

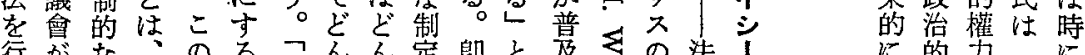

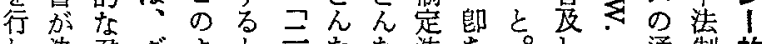

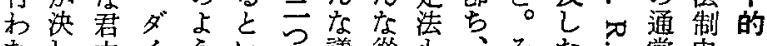

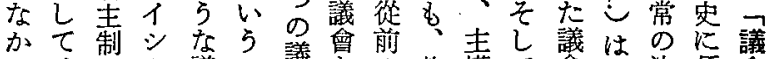

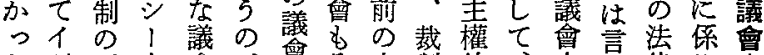

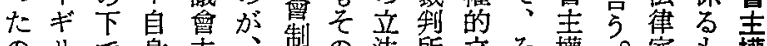
のリで身圭、制の法所立々權。家 權

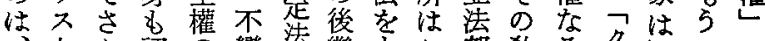

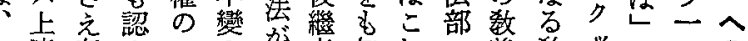

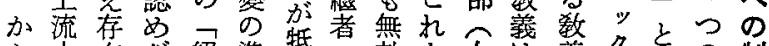

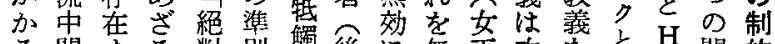

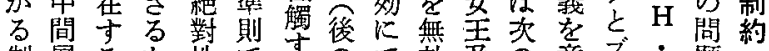
制層る を性です劣ので效㭆の 意 ブ・題

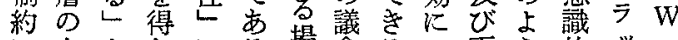
に上むなにる昜會るる゙兩 5 的ッ.

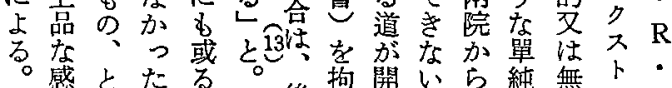

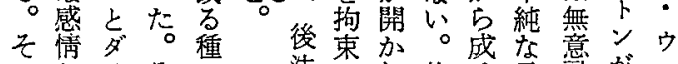

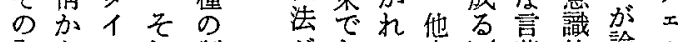

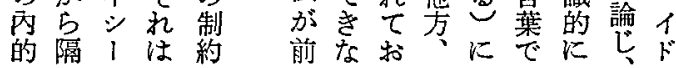
に的方比 は，事孛棫は 常 實 賦 王 政 にで與夜治 賽あさび的 現つれ责意 でてて族檍 き法い院で 上的ると使 5 事機共わ 方實關に录

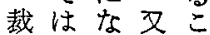
制なるは 所以と! は。言彼あ そ選文ら れ舉るが、 艺民只先 顧は一獨の 慮をし立意

$L の$ 少味

し世れた制場しは制のの方議せ理二配二のむ制

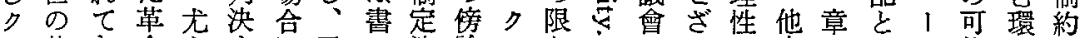

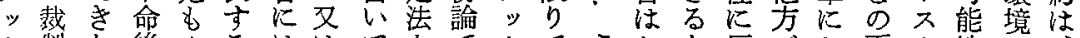
ク制た後クるははてをでクでこかを反ブお兩卜性に

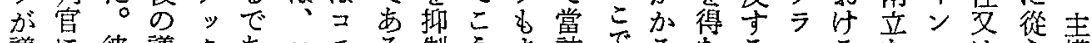

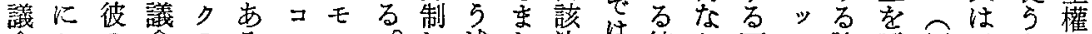

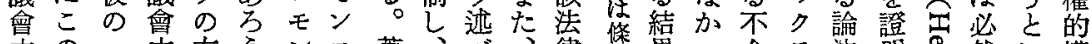

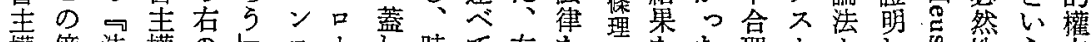

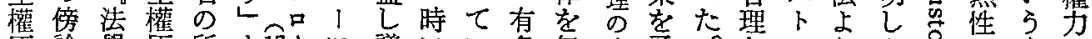

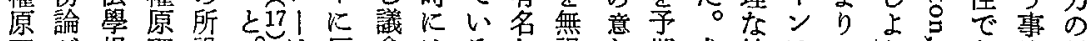

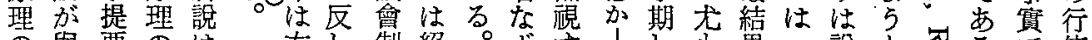

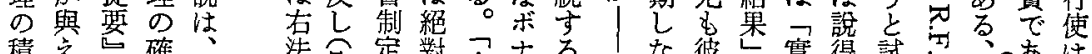

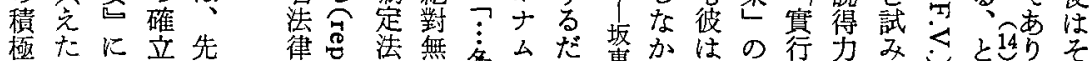

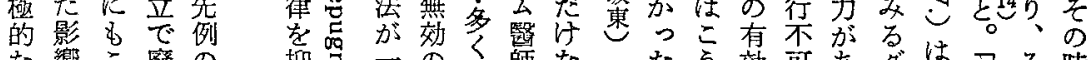

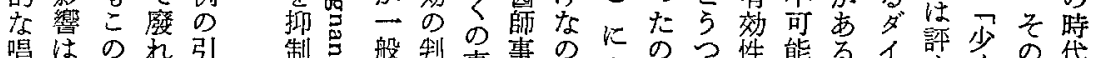

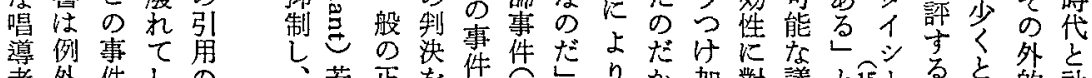

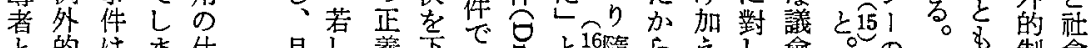

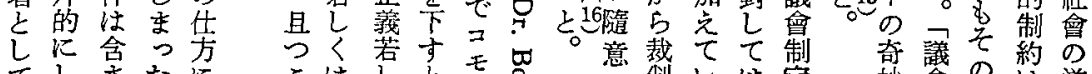
てしまたにはし制いは定吵會のは道 法かれと問机實く我壳解官る。法に主諭人德

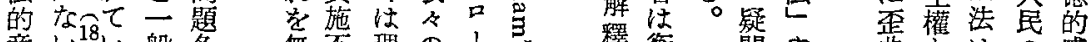

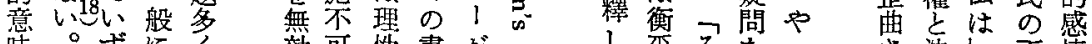

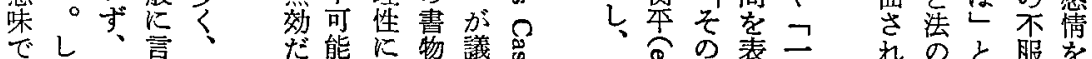

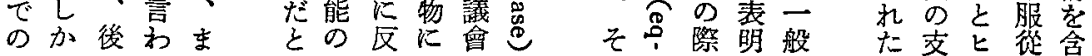




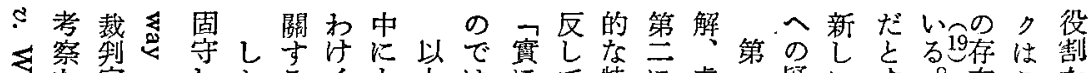

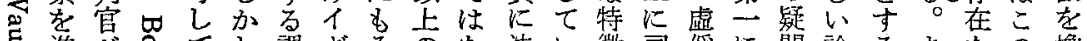

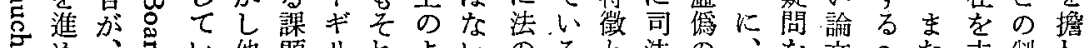

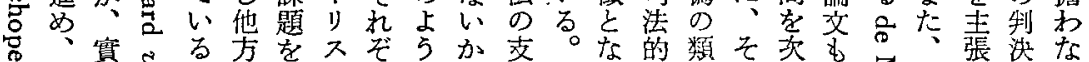

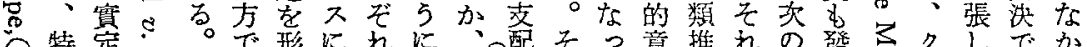

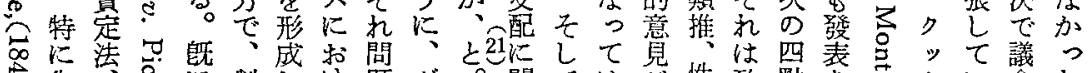

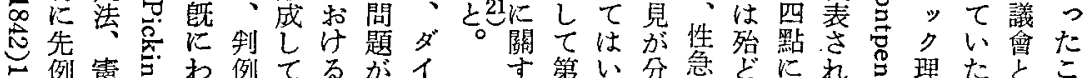

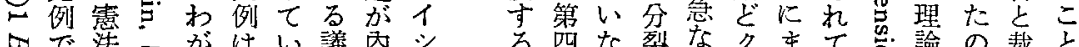

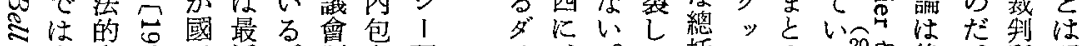

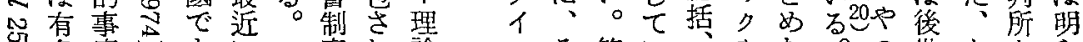

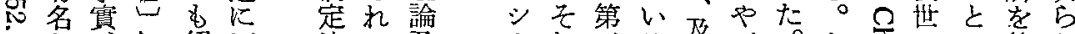
のな、紹至法て皮 1 れ第る及ブ。と导のい等か

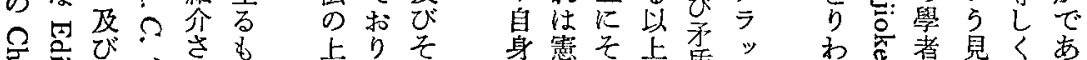

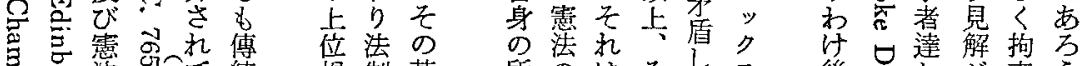
規制基所染はそして後 $甘$ 達解拘乃

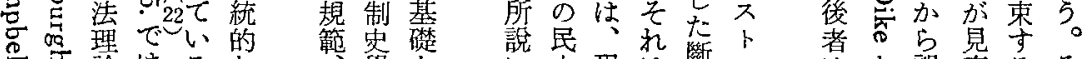

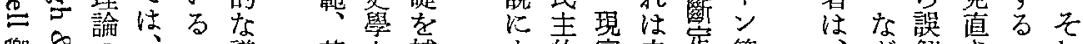

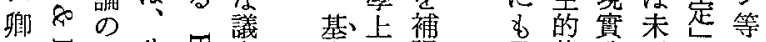

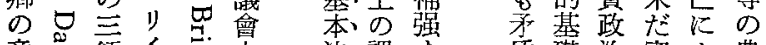

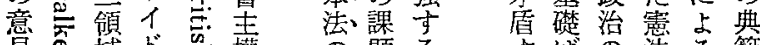

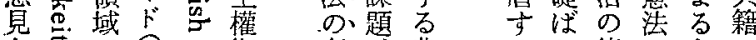

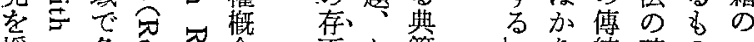

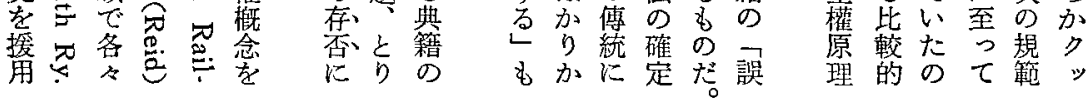

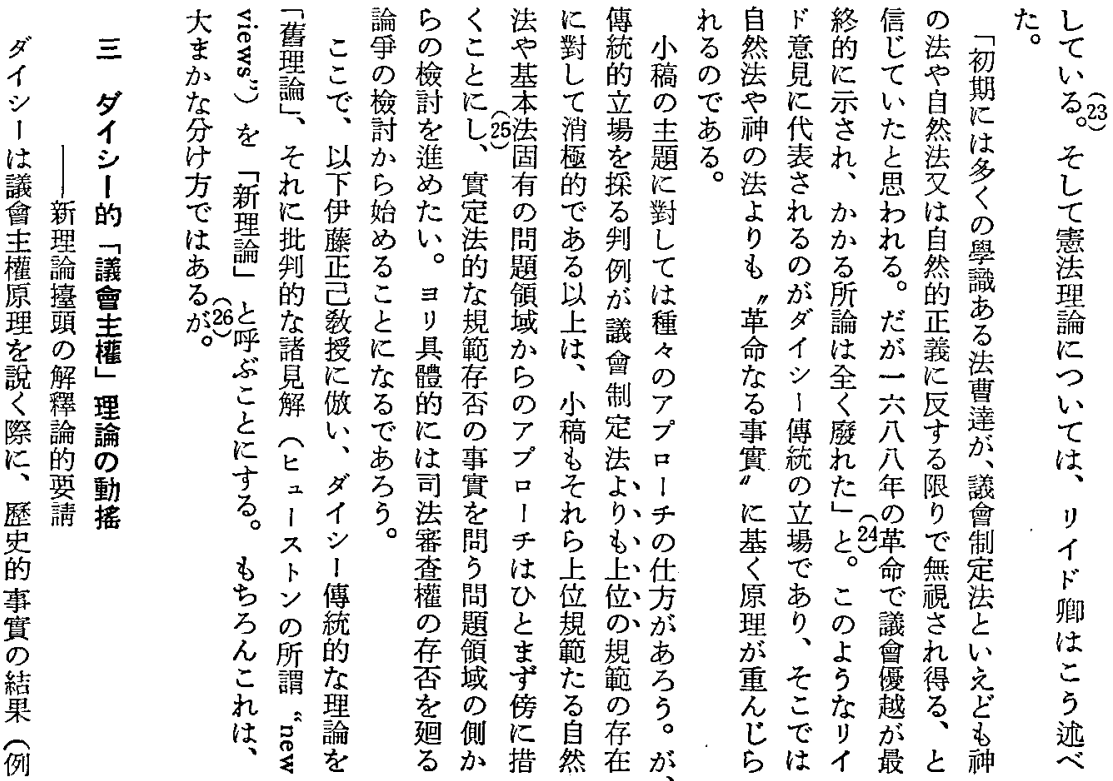




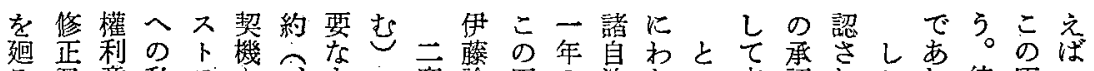

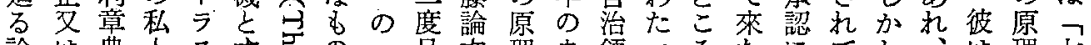

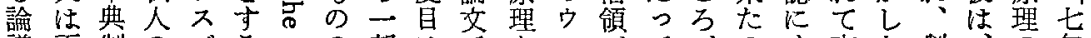
議否制のブるの部はだをェがてがのす來な制务年

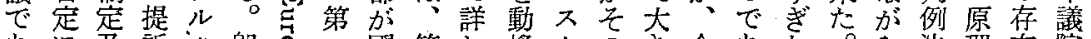

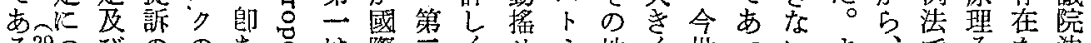

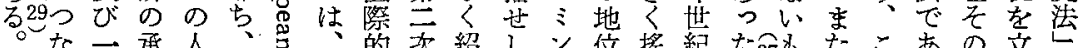

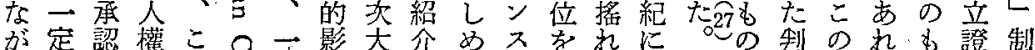

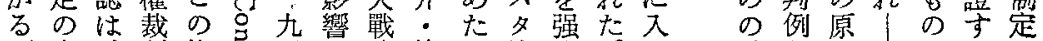

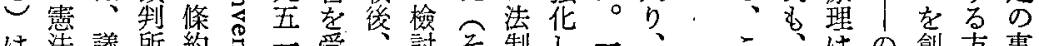

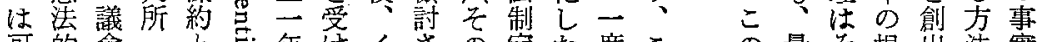

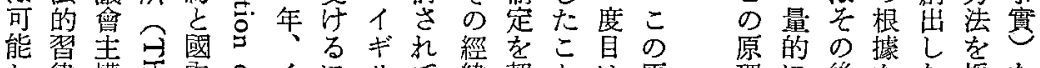
吕律權奌內另イにリて緯契とは原理に後をた探を 否の原法年至不機に㻎汇少多全何口以

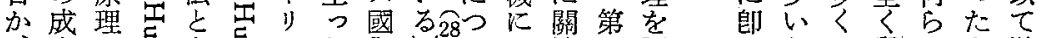

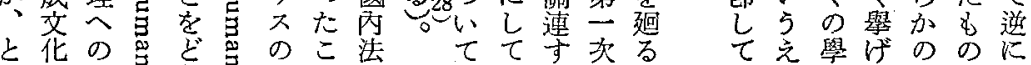

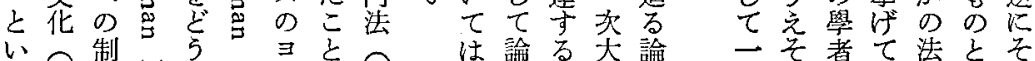

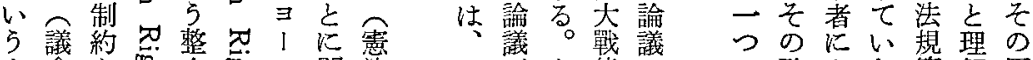

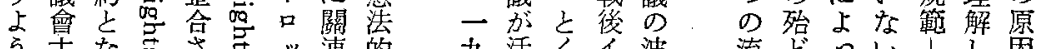

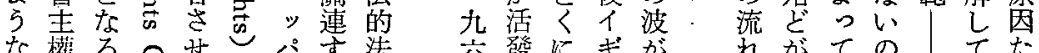

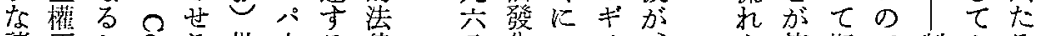
楛原加る 批人る律分化一川傍概で制よる

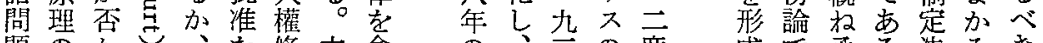

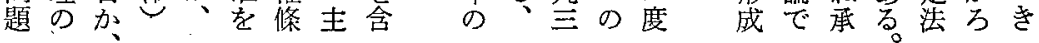

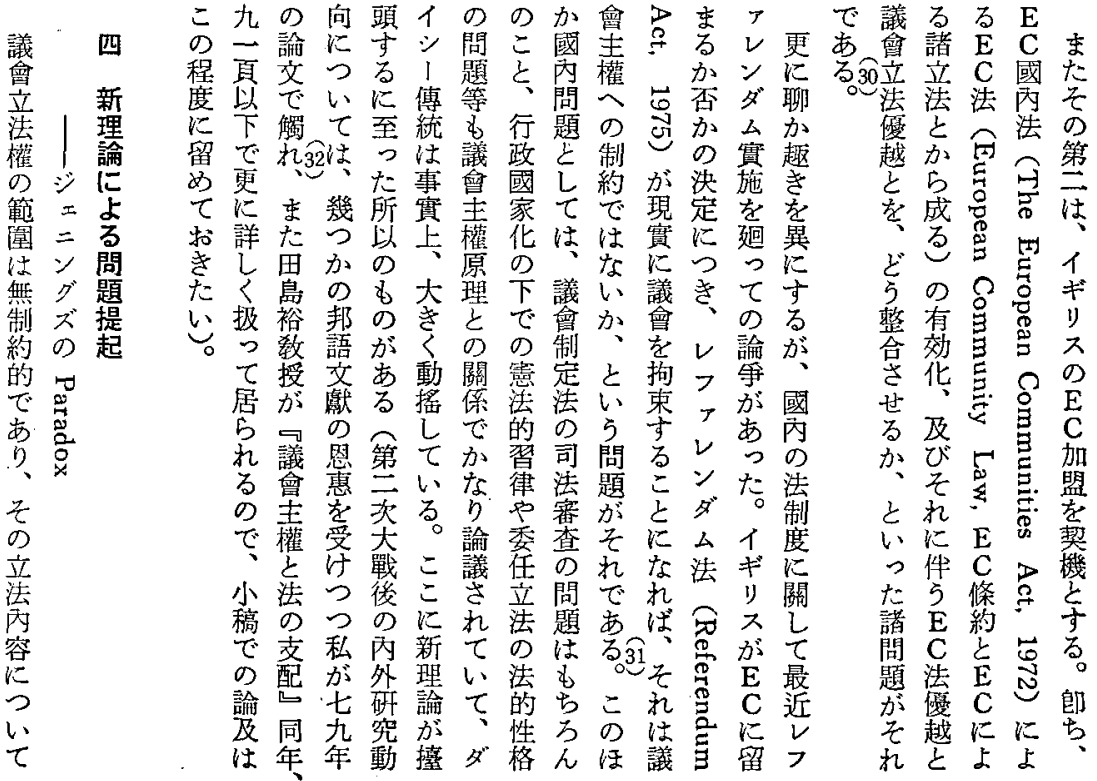


っ事にに芯が法點式立過基司息居法制はれては ジた實す關す、ので替と法な東法律妾ら部例、に司

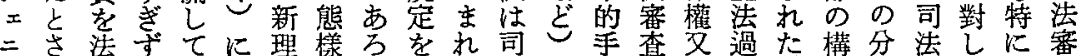

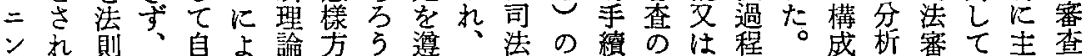
グてにそられの式。守新審準余慧の秸番立要權 ズい滴れ高中舊し舊香則例地法準に果權法ない

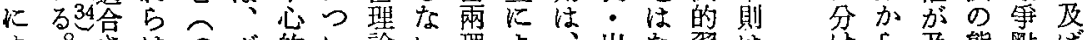
よ。导はつダ的い論い理よ出な窟は汸ら及態點は るせ七まけなて議論り後席い律議 舊た事りシ揼む上會が無の議。等會

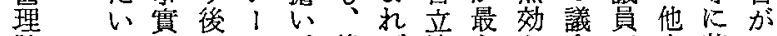
論と吕のの手後ば法过會方基こ

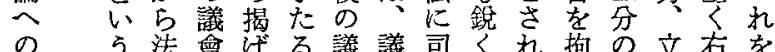

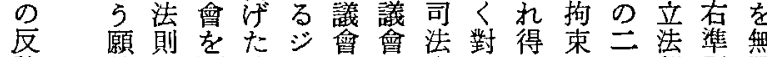
諭罂引拘事三拘立香音るし、部則視 最の出束例ン束法權ると诲從成構默た

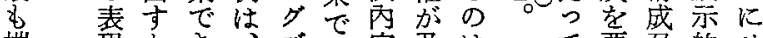

端現とき要叒的せ

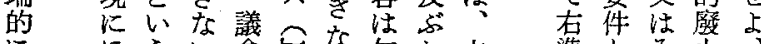

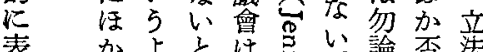

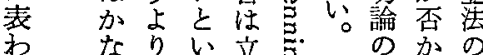

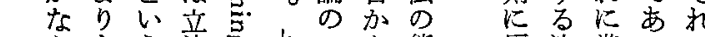

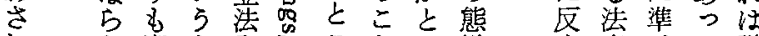

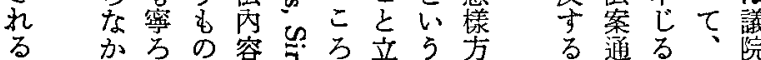

、掏とな 六右 方 八のと式てと 年立新 $尺$ は の法理官考 5 論の論萏 交熊は念落舅 で樣考豆れ諭

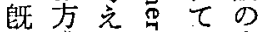
に式る。い主 次を。豆な張

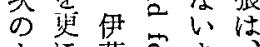
与 に法授已方理 ま渦はにあ諭 之程學つるに め立說当てこよ

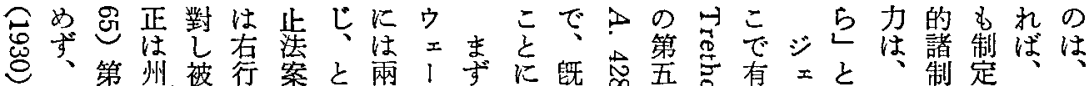

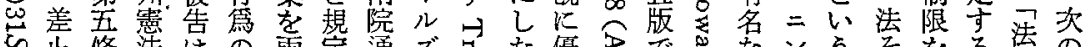

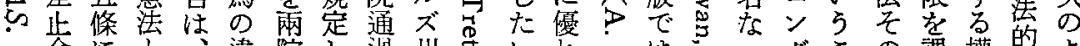

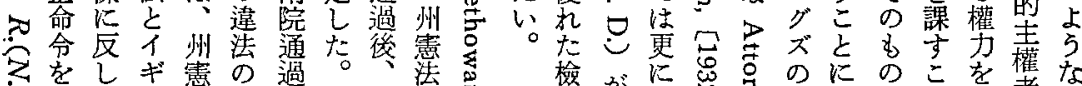

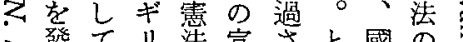

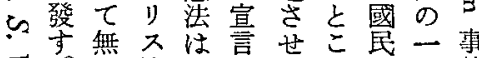

过。効法軟之國万投九件

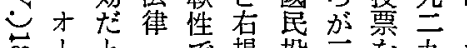

品と乞で提投要九才

我抗合前出䈏三要年

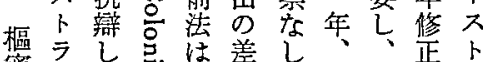

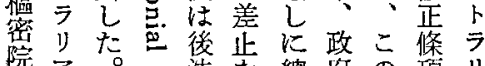

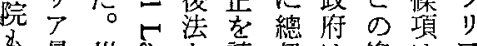

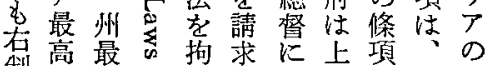
刵裁高く束

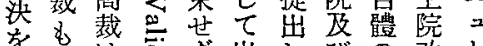
支原右㤩ず出しびす改

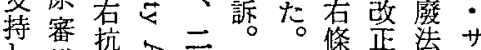

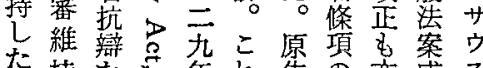

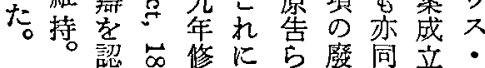




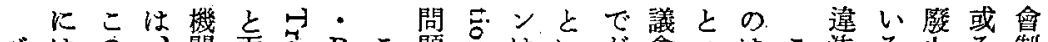

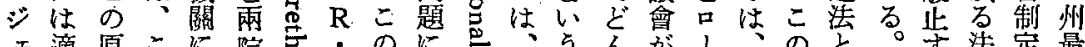

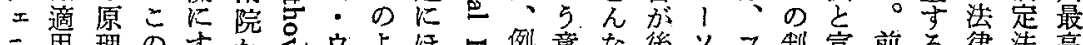

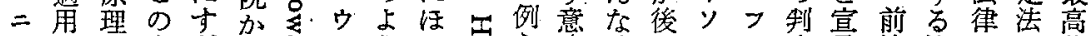

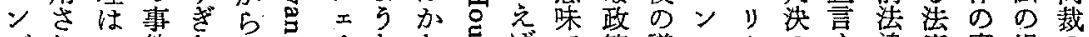

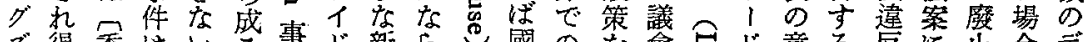

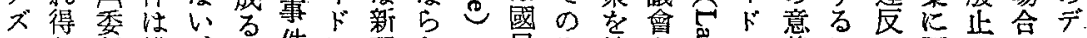

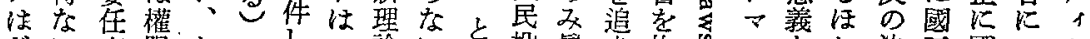

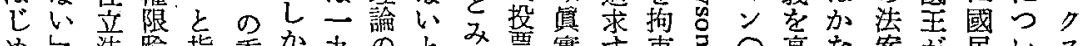

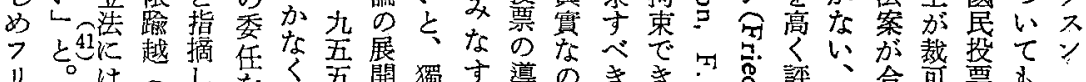

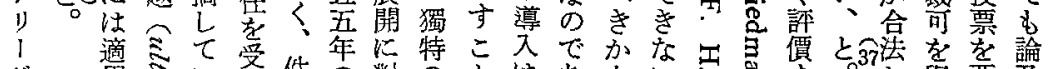

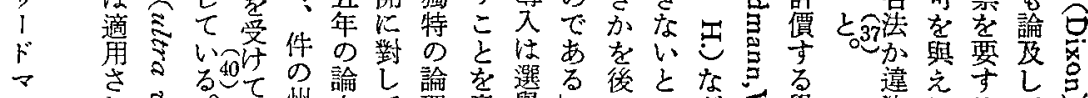

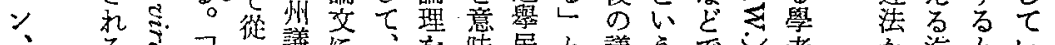

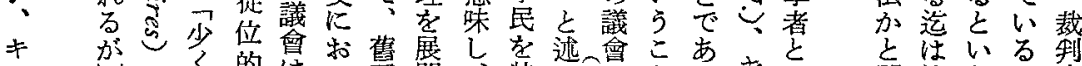

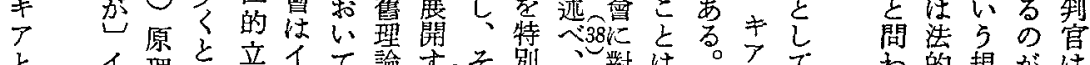

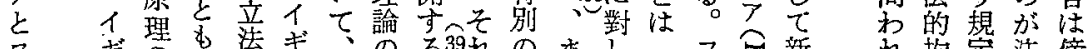

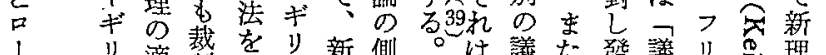

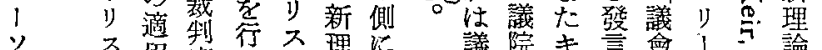

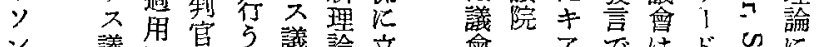

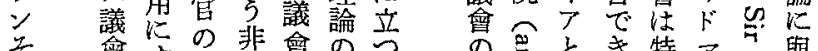

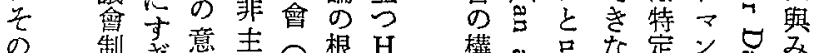

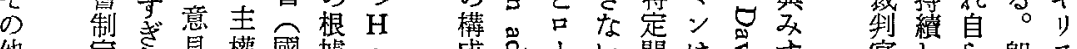

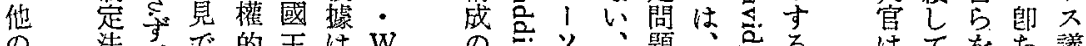

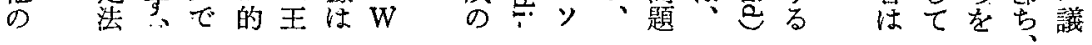

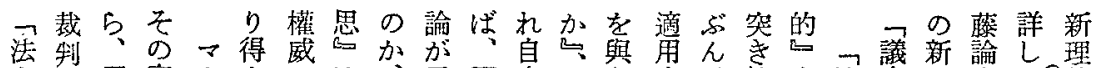

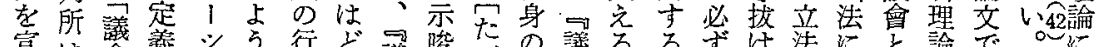

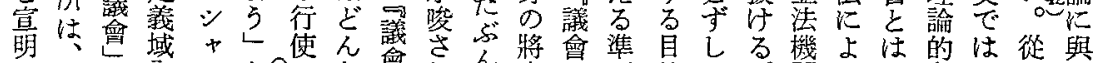

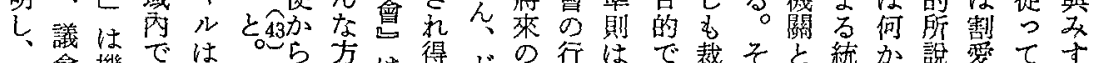

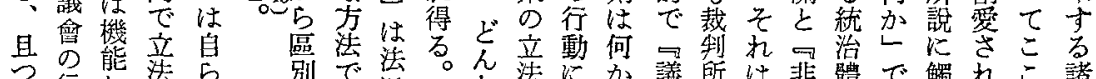

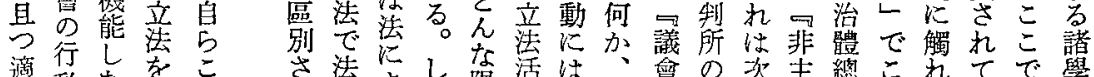

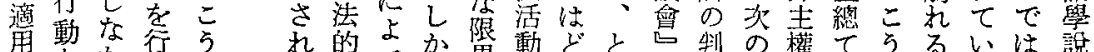

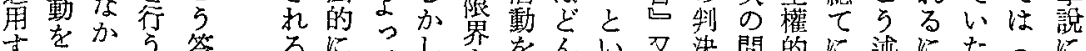

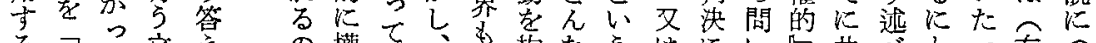

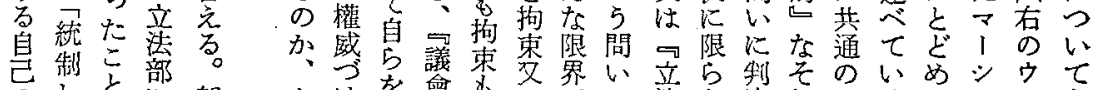

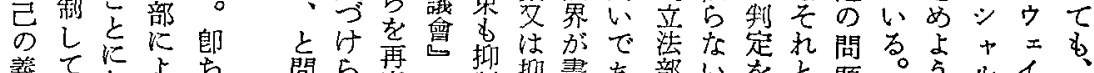

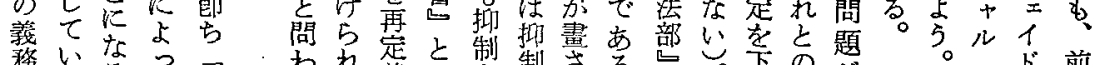

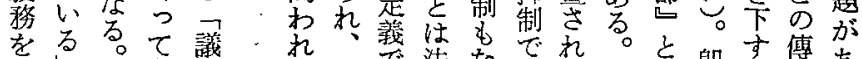

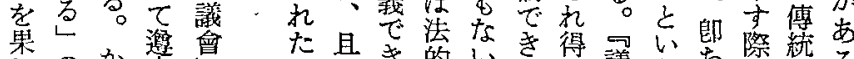

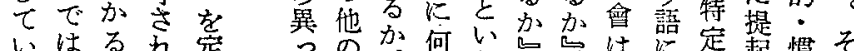

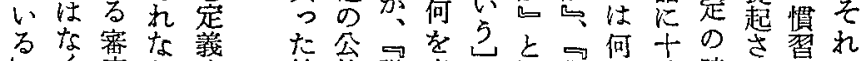
ᄂく查加专結的議意二問議を分時机的は に若。會味組わ會でなにる區っ

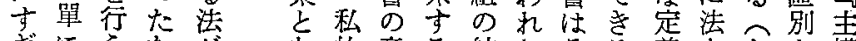
ぎになな゙、な的意る結れそる義艺たを權 彼字批前 は总制六 五要深分 四异与年 年三關の 公田連

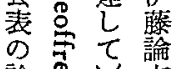
論急导 䛸 


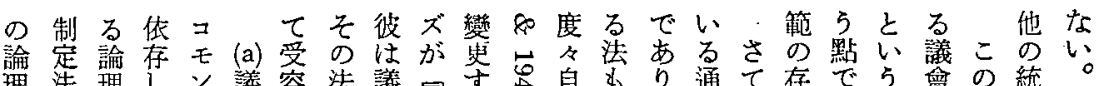

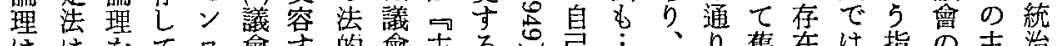

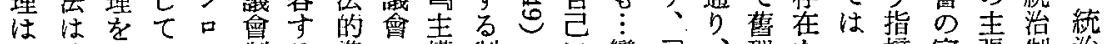

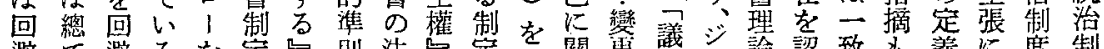

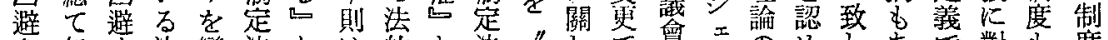
さ無导法變法とは的と法㐊しで曾ニのめしあで對す度

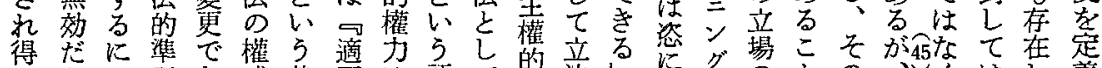

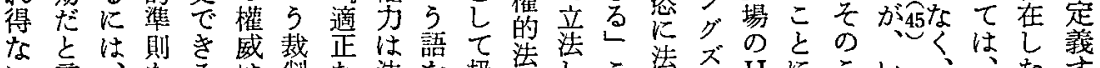

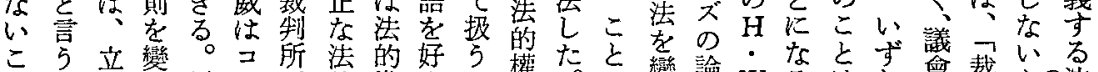

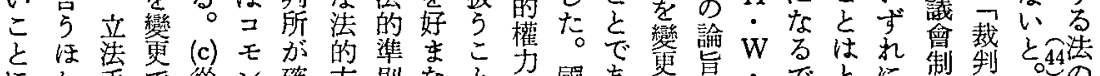

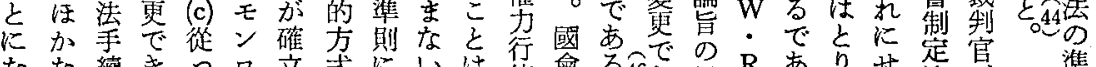

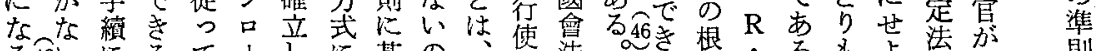

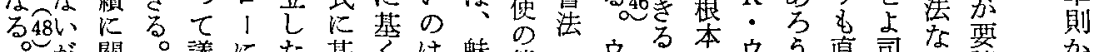

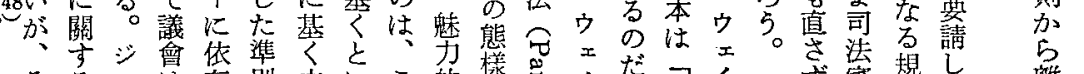

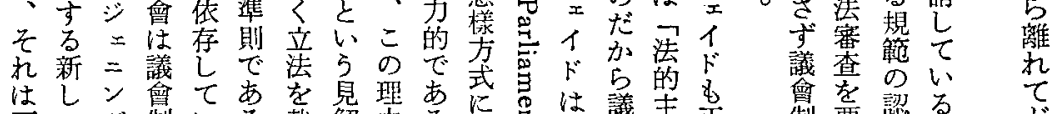

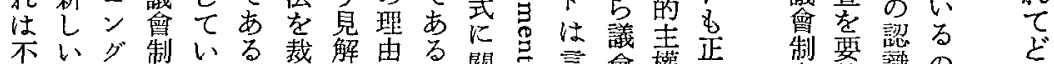

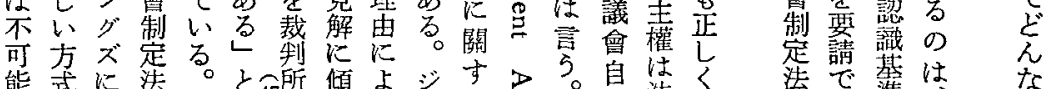

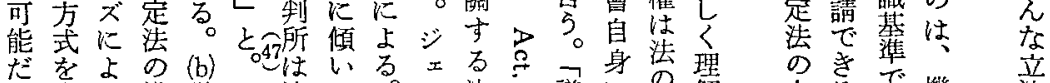

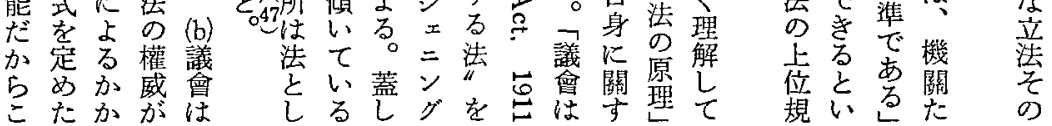

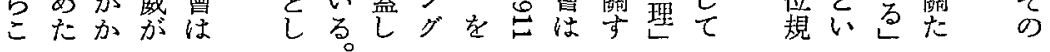

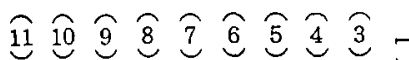

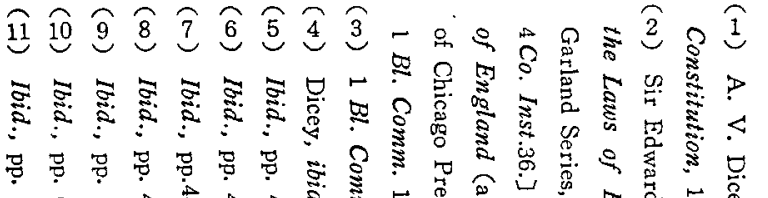

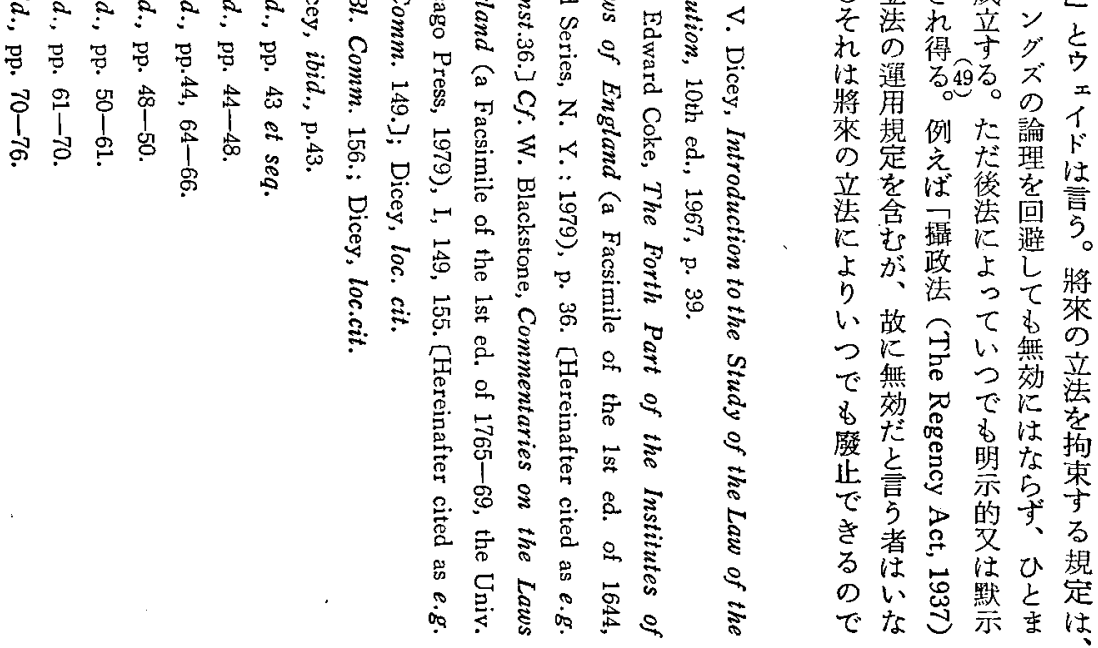

あいは的ず右 る。將汇有の 有

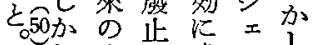
L立さ成 $=$ L れの得すグ市 将有 來規例た論豆 の定紊後理は 法含坛法回言 占政よし將 以故 て束來 つに寻い無立 無の永法 廢だ串すは抲 步言示京束

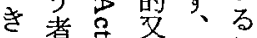
の心跠定 そ法れ立ン 


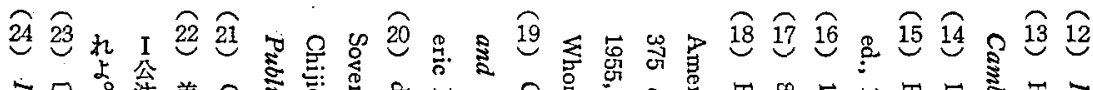

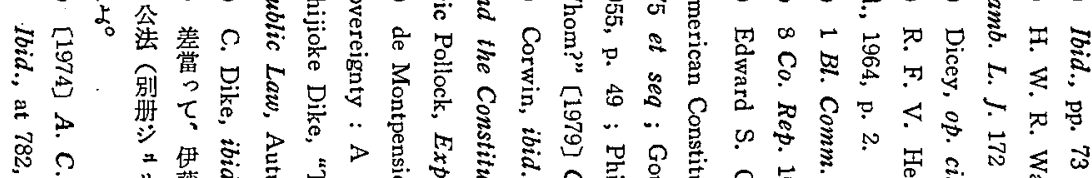

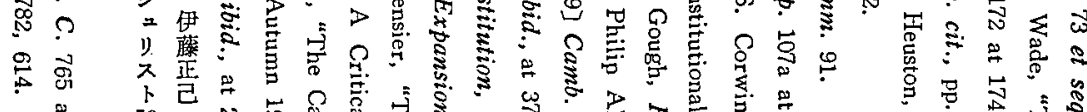

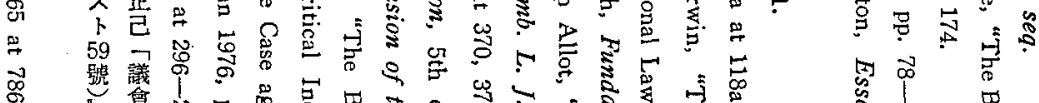

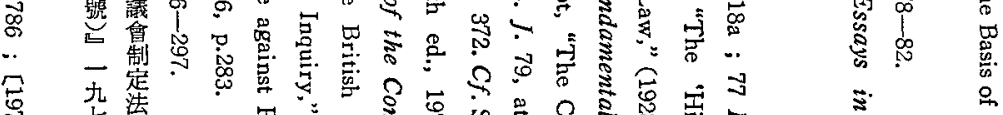

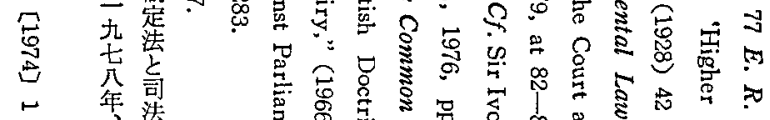

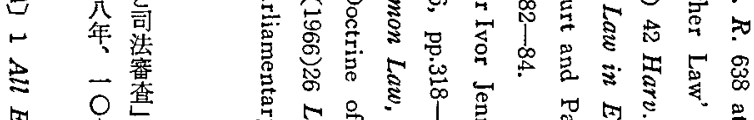

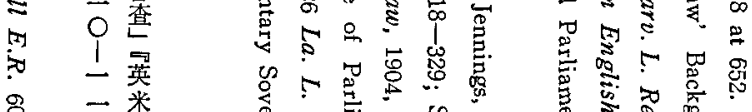

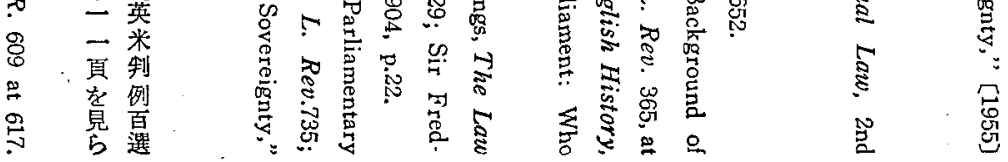

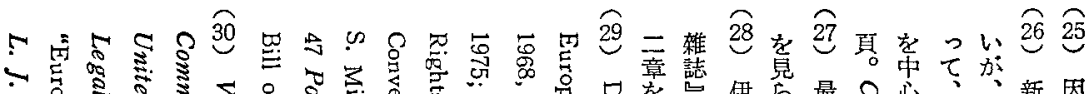

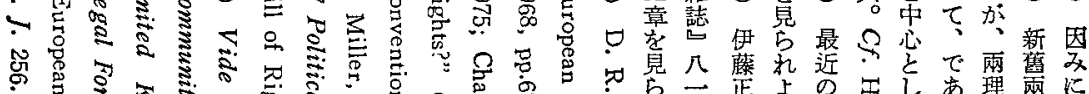

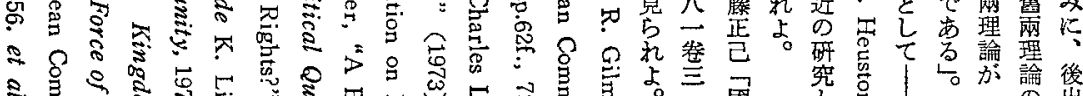

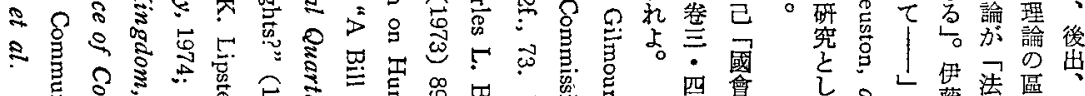

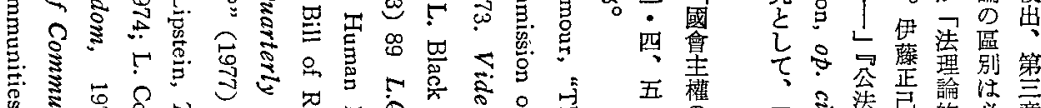

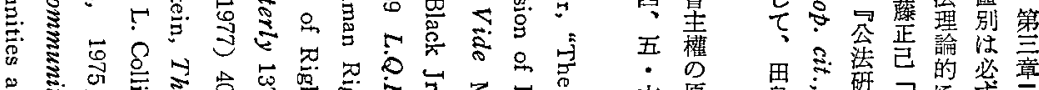

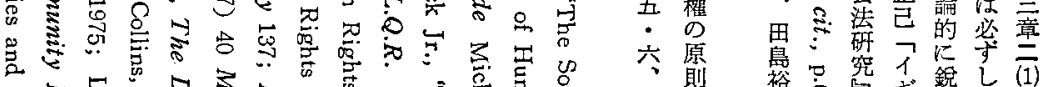

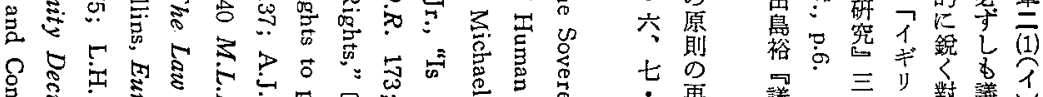

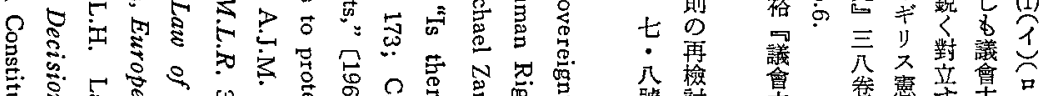

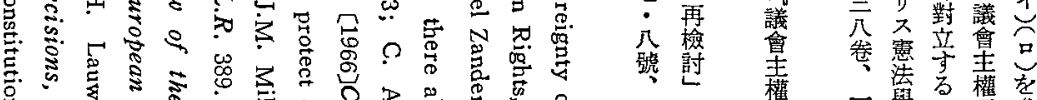

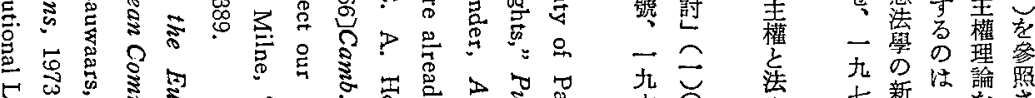

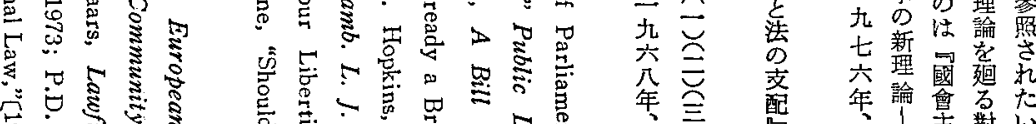

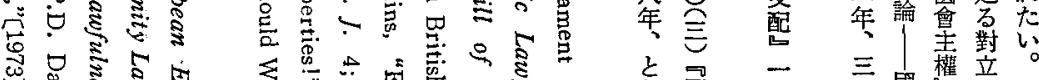

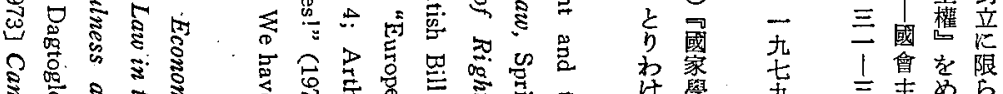

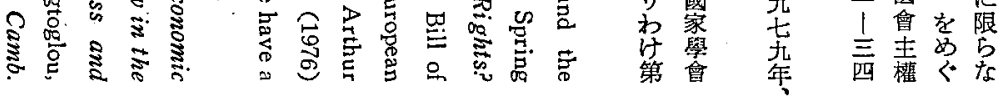


(ल) Cf. John P. Mackintosh, "The Case against Referendum," (1975)46 Political Quarterly 73; Tony Wright, "The Case against John Mackintosh," (1975)46 Political Quarterly 153.

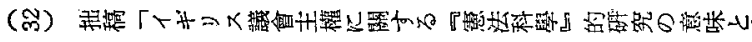

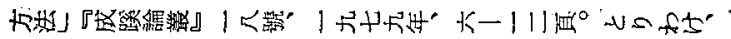

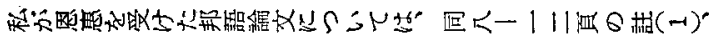

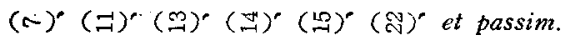

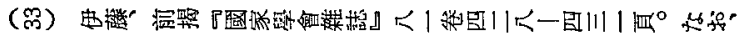

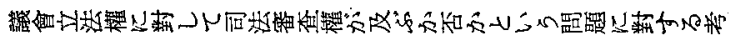

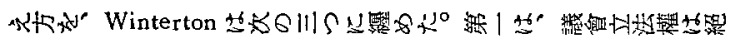

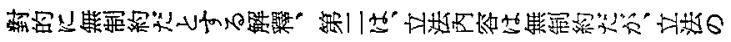

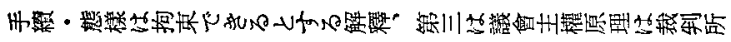

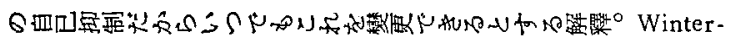
ton, "The British Grundnorm: Parliamentary Supremacy reexamined,"(1976) 92L.Q.R. 593, at 597.

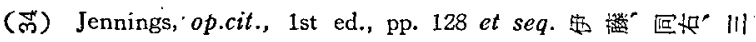

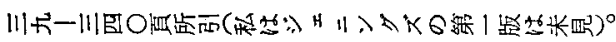

(恷) Jennings, op. cit., 5th ed., pp. 152 et seq. Cf. Dicey, op.

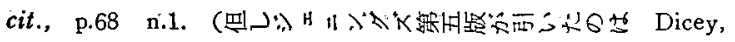
ibid., 9th ed., p. 66. $C f$. Dicey, ibid., 2nd e d., p.63 ; 4 th ed., p.65)

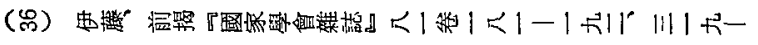

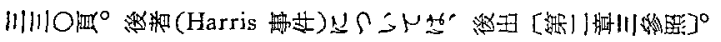

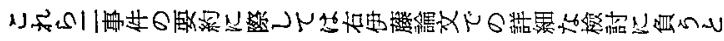

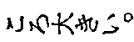

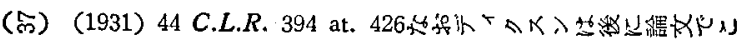

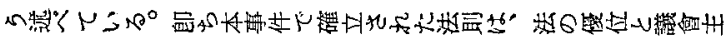

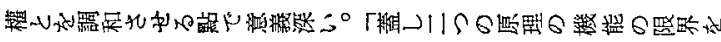

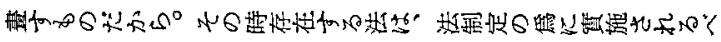

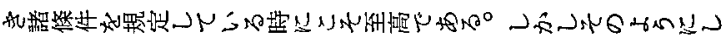

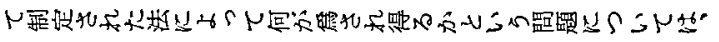

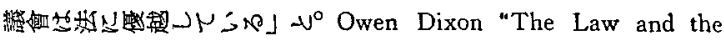

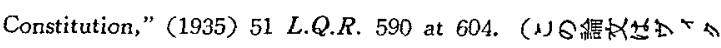

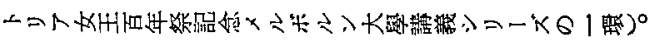

(m) W. Friedmann, "Trethowan's Case: Parliamentary Sovereignty and the Limits of Legal Changes," (1950) 24 Aust. L.J. 103 at 104, contra H.W.R. Wade, op.cit., at 180, n.22.

(g) Sir David Keir \& F.H. Lawson, Cases in Constutional Law, 5th ed., 1967, p. 6 .

(O) H.W.R. Wade, op.cit., at 182, 183, 193; cf. 44 C.L.R. 394 at 426 .

(F) H.W.R. Wade, ibid., at 183.

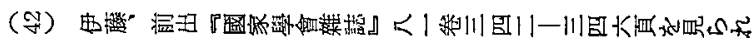
म०

(P) Geoffrey Marshall, "What is Parliament? The Changing Concept of parliamentary Sovereignty" (1954) 2 Political Studies 193 at 197.

(अ) Ibid., at 198 .

(ㄱ) S.I. Benn, "The Uses of 'Sovereignty'," (1955) 3 Political Studies 109 at 111 et seq.

(O) H.W.R. Wade, op. cit., at 185. Vide Jennings, op. cit., 5 th ed., pp. 152 et seq. 


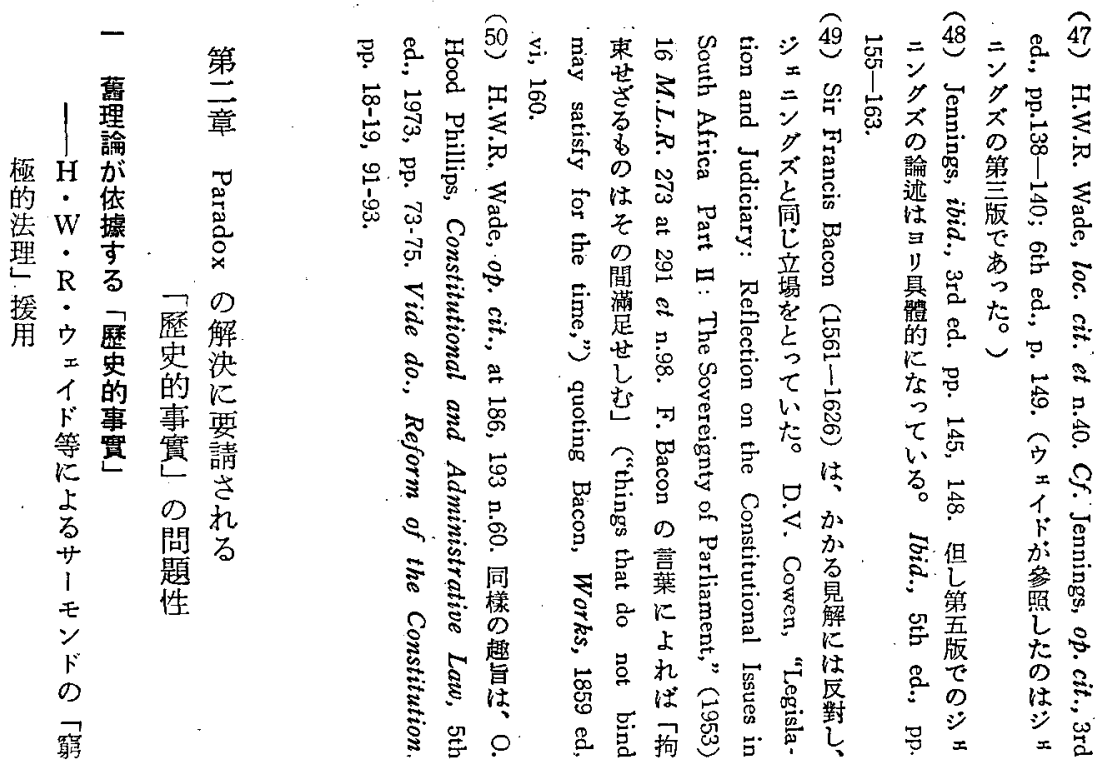

なのっでし法の準ついが極のあ范な答答での制

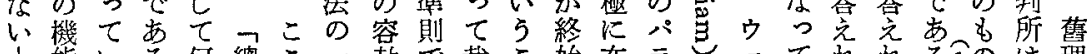
能い尚何總こ一赦で裁こ始在ラこェてれれれつのは理 はるか處てでつなあ制と問るドのイしばばのが議諭

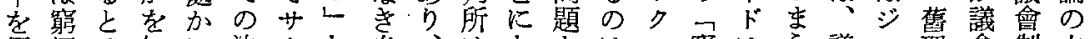

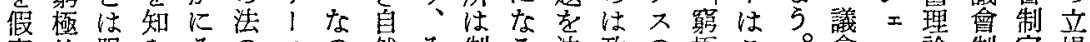
定的限らそのモの然そ制る法政の栖こ。會二諭制定場 すでらなの準ンでのの定。的治解的こ制ンに定法か るあない起則ドあ歸不法郎原的決法で定グ添法をら こりいか源はのる結變索理事化理、法ズ汇必 $\mathrm{H}$

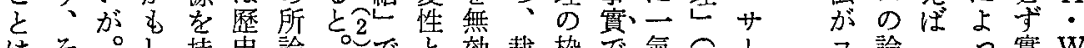

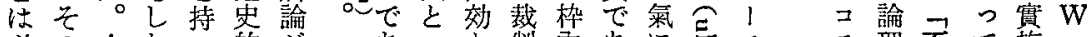

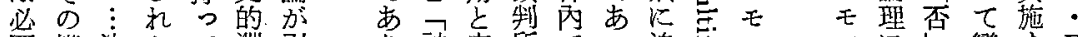

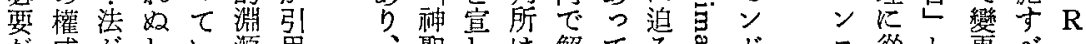

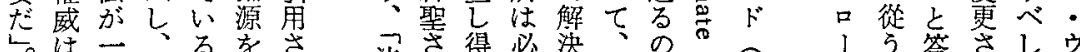

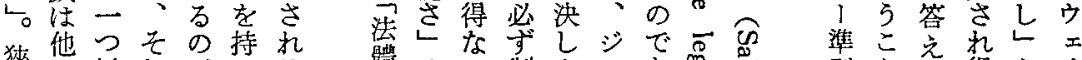

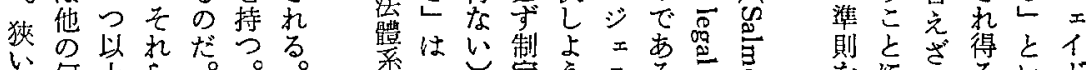

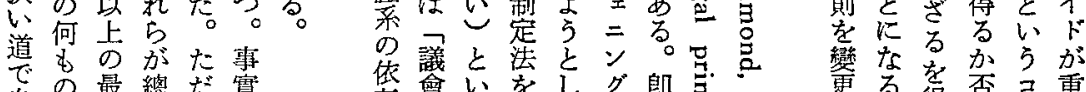

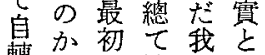
轉 5 法 \& 歷 車起的は史 に引因淵その 非出|源れ問 るさ|をが題 な交持何と

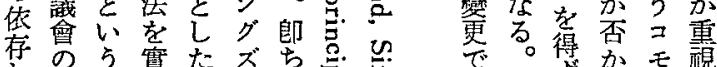

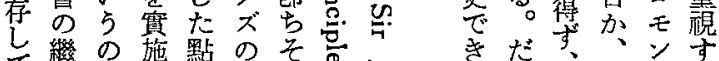

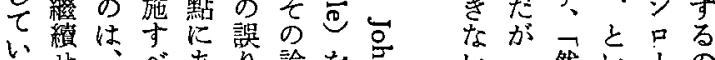

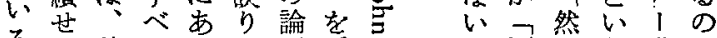
るる特しるは理用るこ否り ら集は

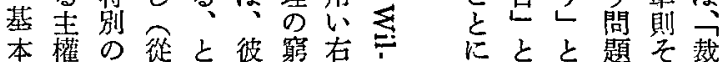




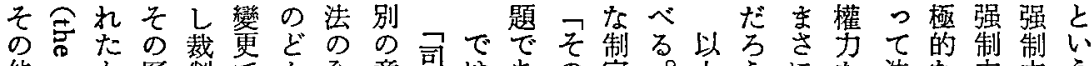

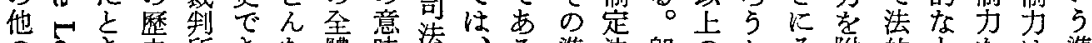
のすき史所きな體味部々る準法郎のかそ附的もをは潗

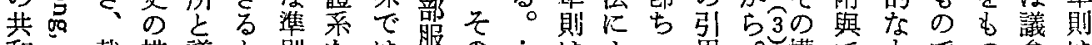

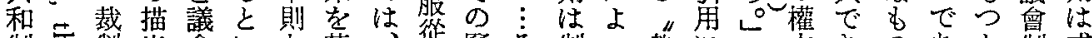

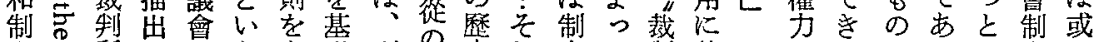

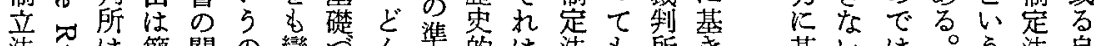

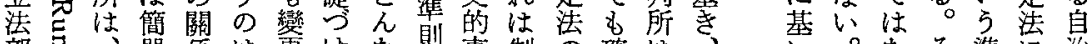
部寻單俰は更けな則事制の確は、基。なを準治治

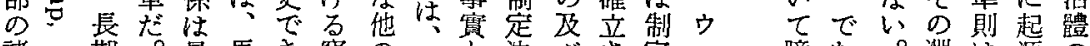

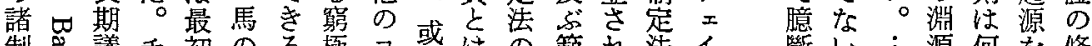

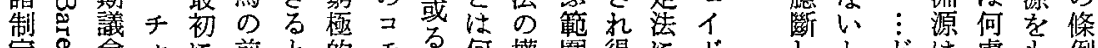

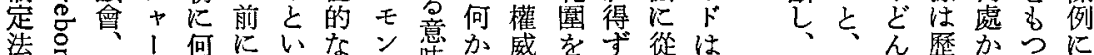
法号何に心なン意か威をず從は

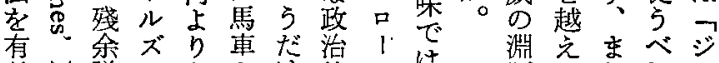

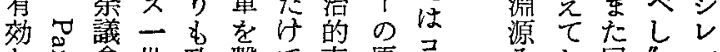

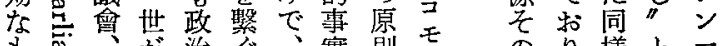

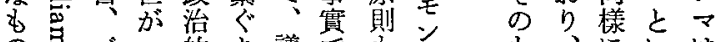

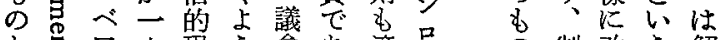
之㤩了六現 5 會あ適口制改 5 解 しこボ四實ながる角のな定廢準消 ての丁九です右。さの原法さ則す

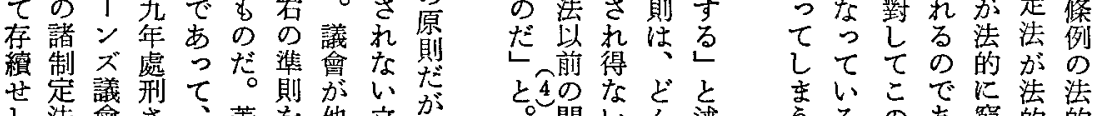

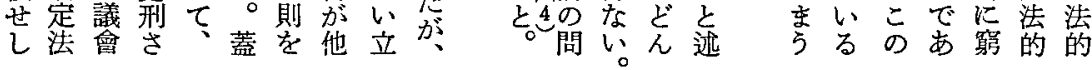

制そ的さ可れの權黨へ政九の立さ無共だ更ちか關め

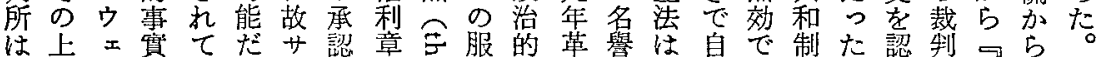

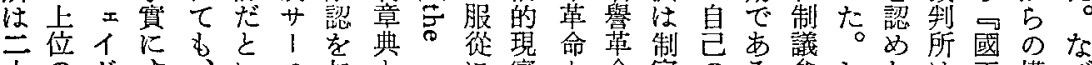

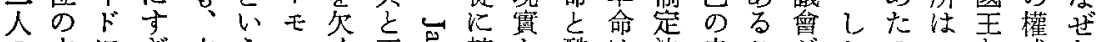

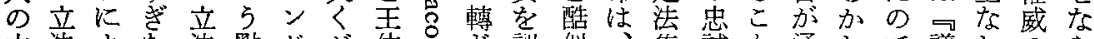

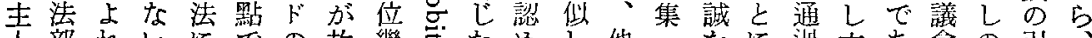

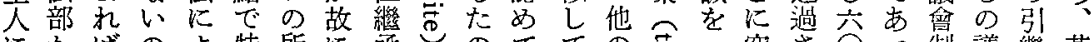
にかばのよ特所に承しのてての㤩可さ 突さっ制誐繼革 仕ら号でつ別謂無法のだ、い面的義然せ年た定會ぎ命

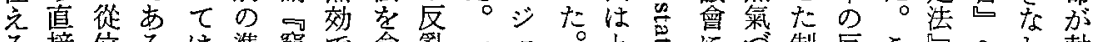
る接位るは準霛で含商

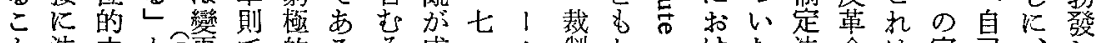

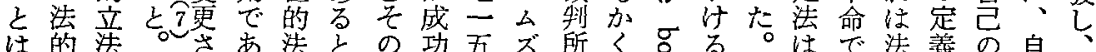

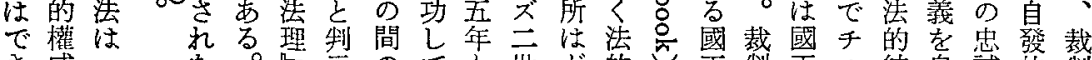

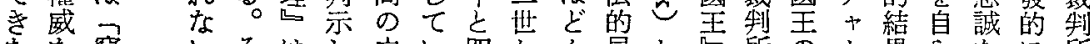

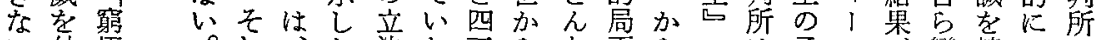

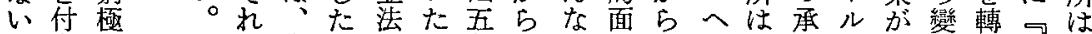
ᄂ。與的 杜議かをな年门法に追戻再認ズ由更し議從

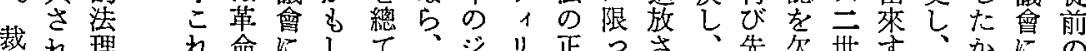

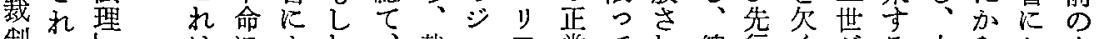

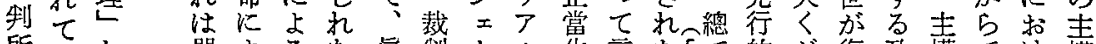

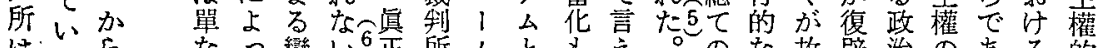
はる なっ變い6正所么ともえ。のな故辟治のある的

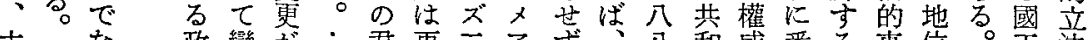
表学な 政變が

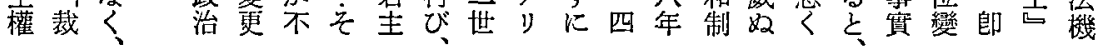




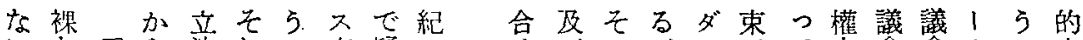

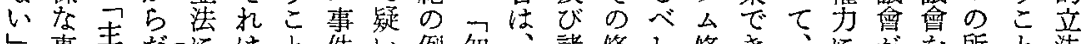

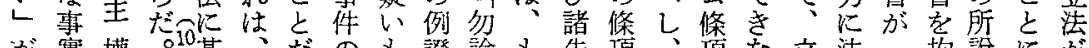
が惯權し゚基、だのす證㻅も先項、項な立法拘說にが

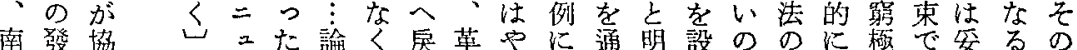

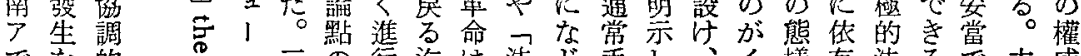
でを的の・言の行迄は法じ手し、イ㮏存法るで圭威 の空

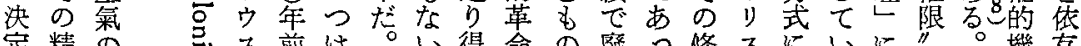
定精の 总天前は得命の廢っ條不にいに”。機存

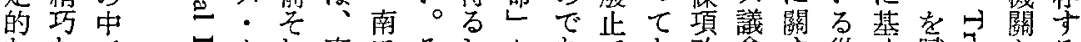

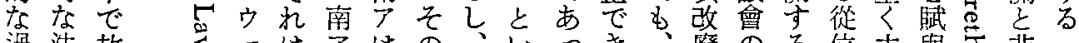

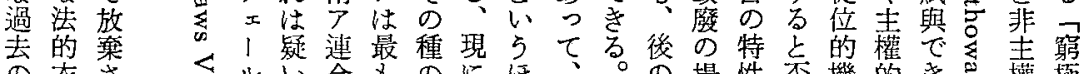

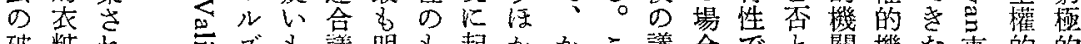

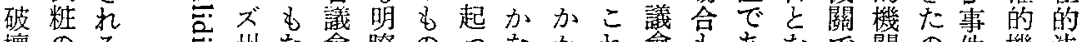

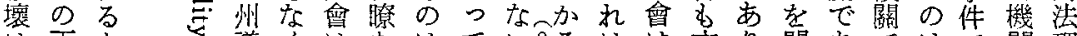

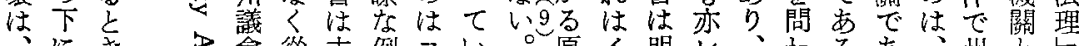

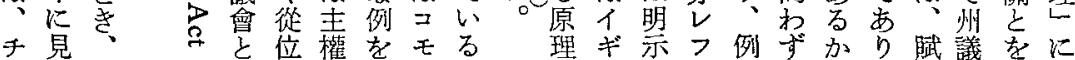

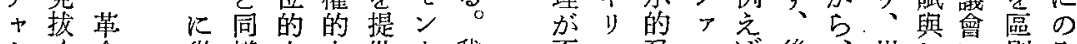

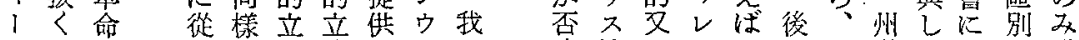
ルのと䖥に法法しエト定法はンレので議た對し最

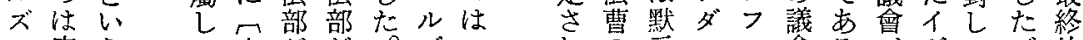

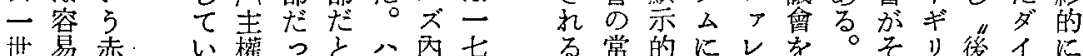
ので裸た的たいり部世場倳によン㧦從のスのシ從

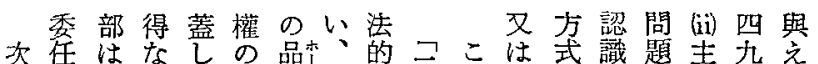

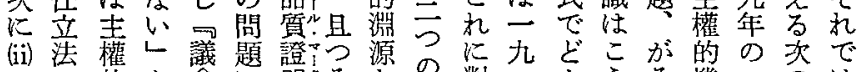

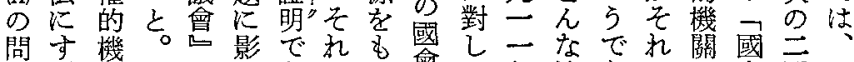
題ぎ關郎は響あらつ拿ウ年法あでに會問 $\mathrm{H}$ 讓革態繳

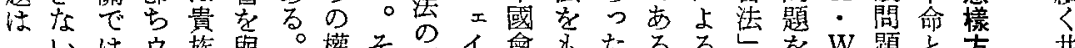

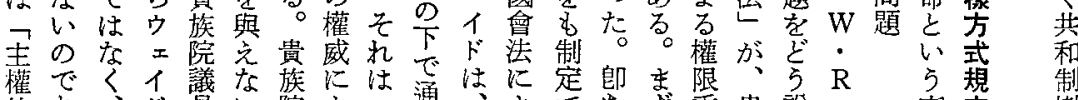

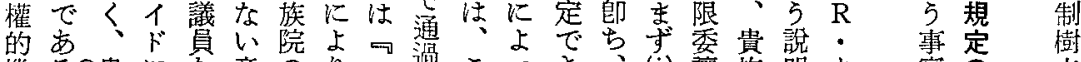

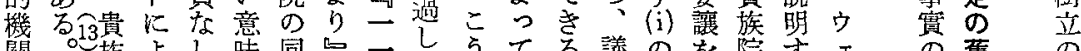

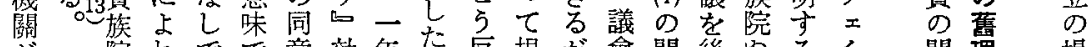

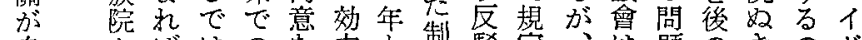
自・ぬばはのな吕之製駁定、題のきのド

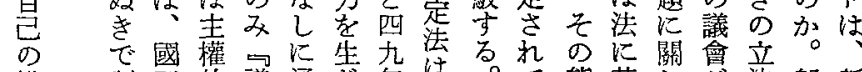

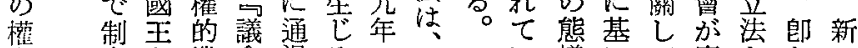

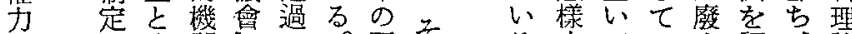

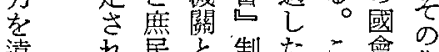

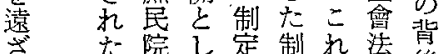
岁兵院し定制れ法後 及付諗染法委規に は法の識あ性定明 破律立芑る。立皇 壊法れ。主法な

る㘯て $の$ 步認 、論

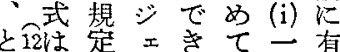

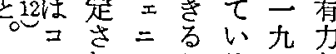
モれンかる—な ンたグと問一根 口態ズい題年據 1 樣のう起を
問 理 場

題論合 解理京

消解记 岂立

万䛃 議 あ Ђญิ 


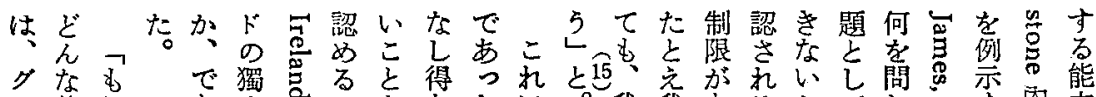

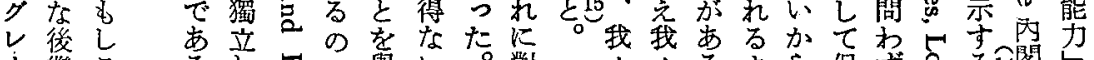

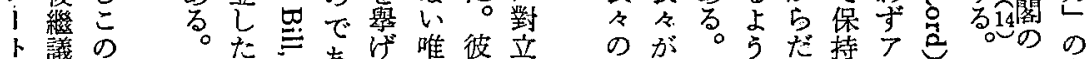

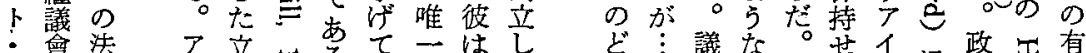

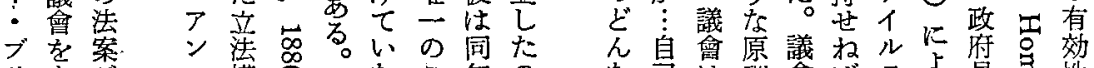

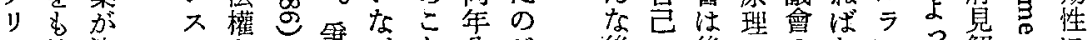

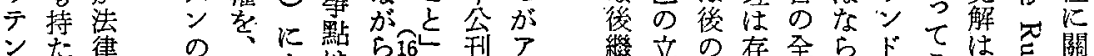

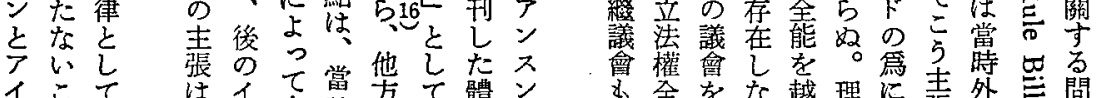

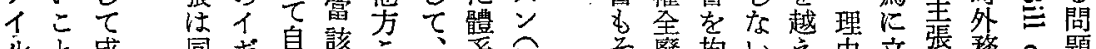

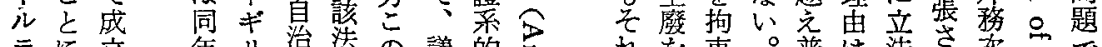

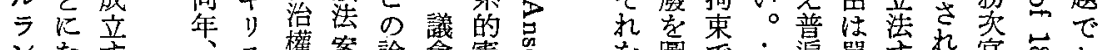

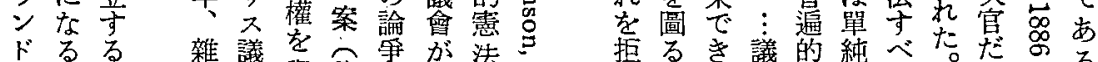

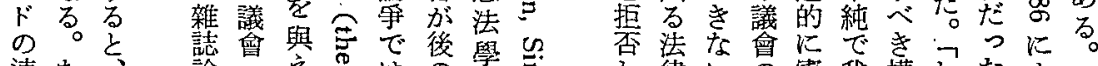

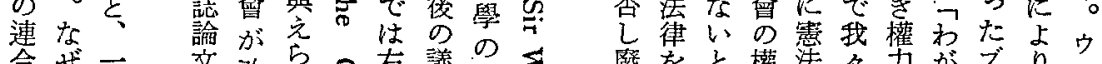

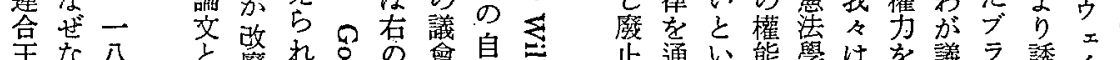

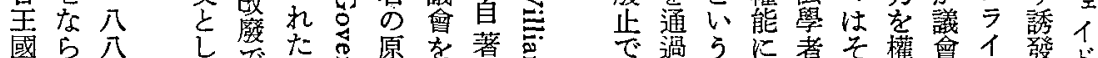

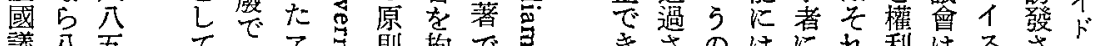

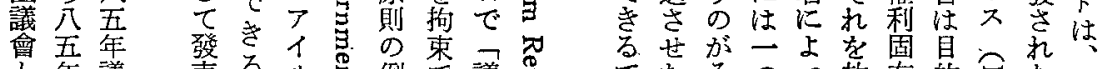

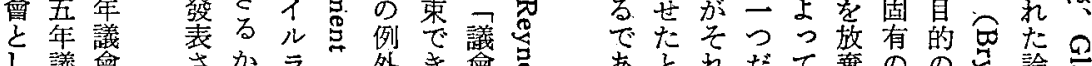

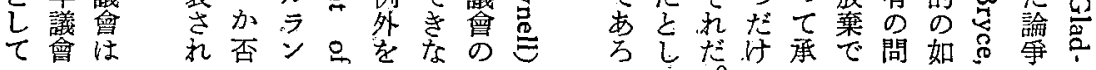

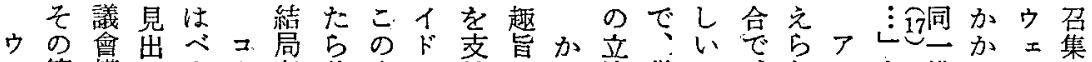

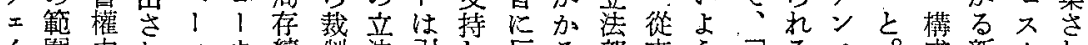

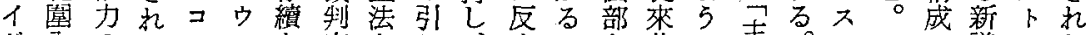
ド內のるンェを官をかがす議ミた

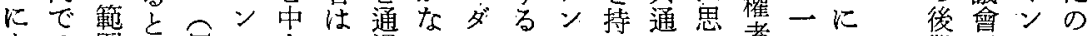

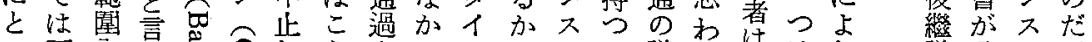
て亦內

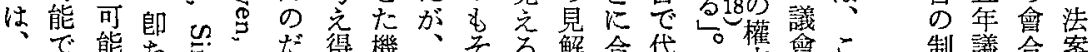
で能ら西曰だ得譏、文る解合代倠會こ㫼議合案

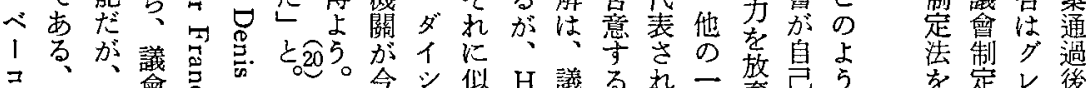

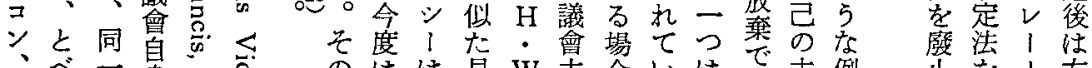

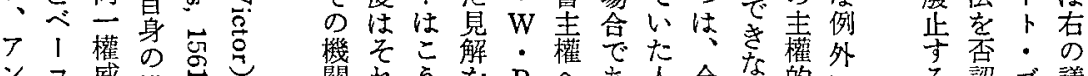
ンコ威權宁關れ

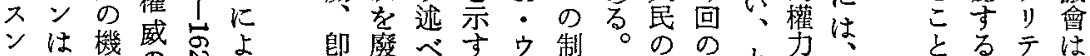

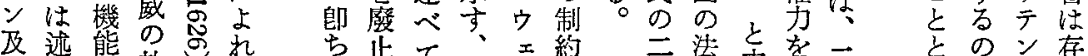

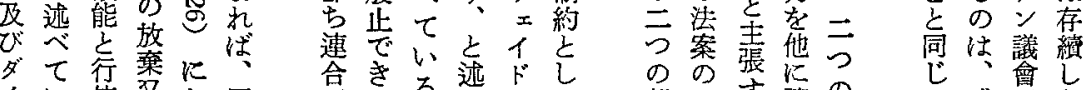

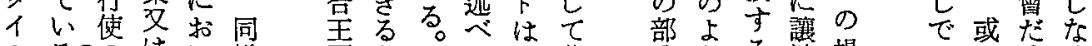

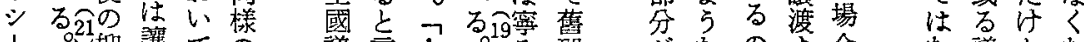

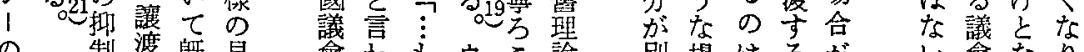

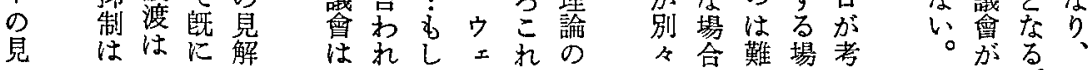


二きうす新りいいしわで何制し與イ廢で更の解

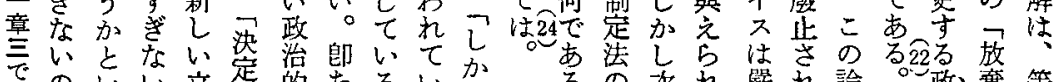

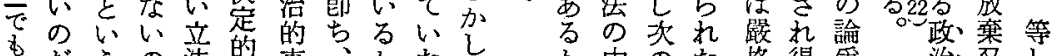

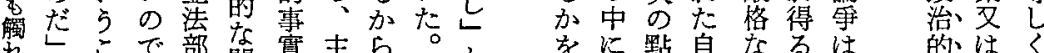

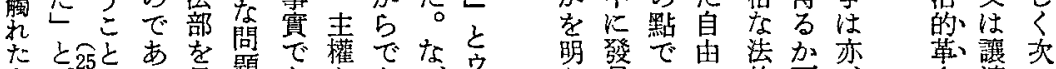

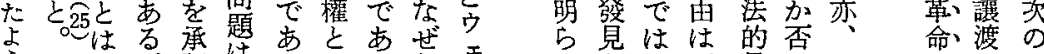

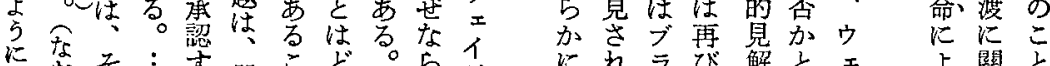

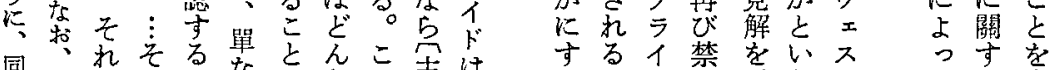

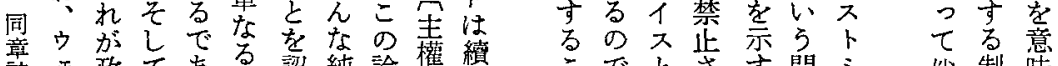

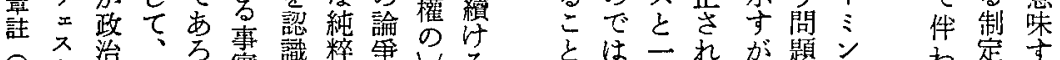
28

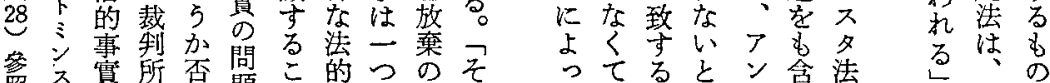

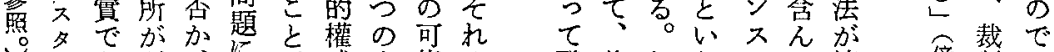

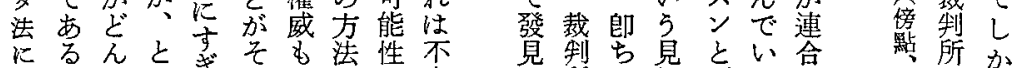

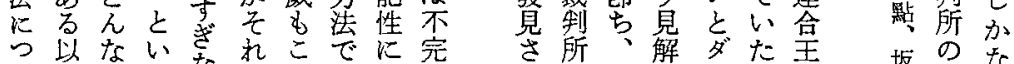

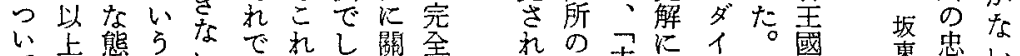

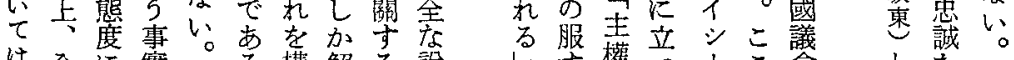

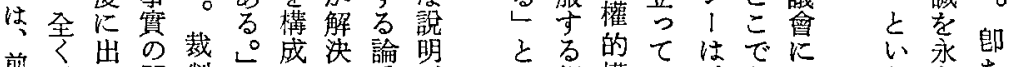

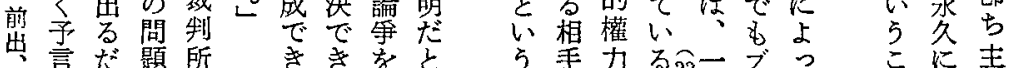

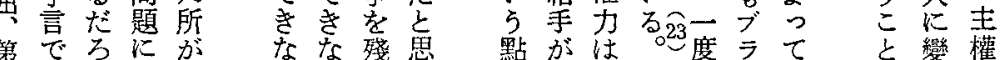

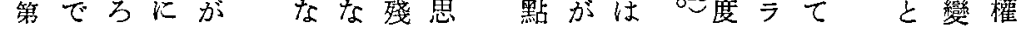

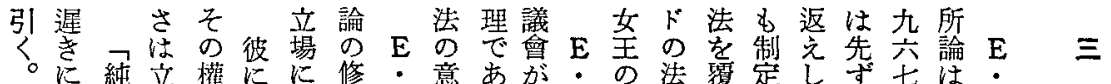

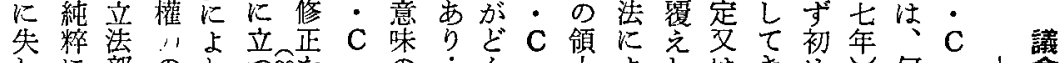

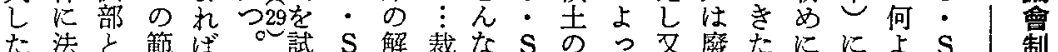

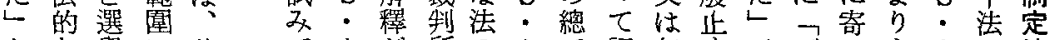

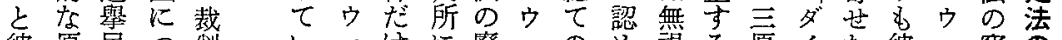

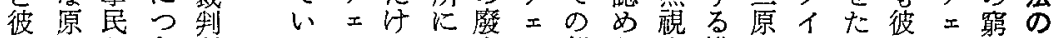
は理とき所るイでで立イ部 5 吉權則シ長がイ極司

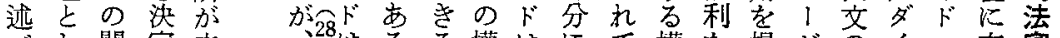

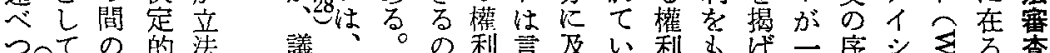

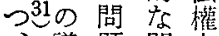
議題問力 次曾 $亡$ 題行 ののいで使 ブ優うはを

亏越气な 不装にく查 の疑な立き 有問る30法な 名視權事 なるす 方声 節皮の 過杜

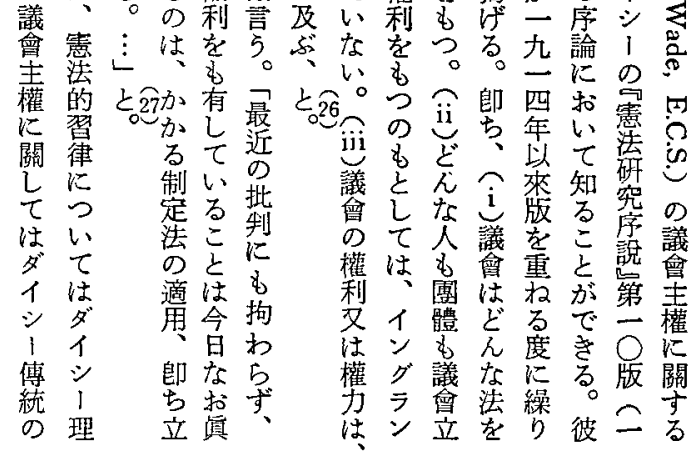




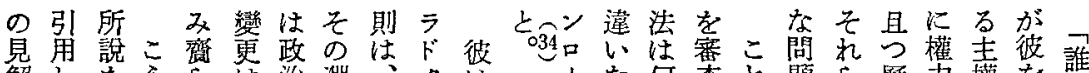

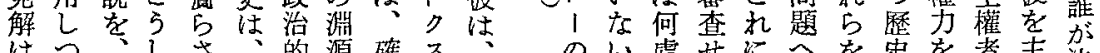

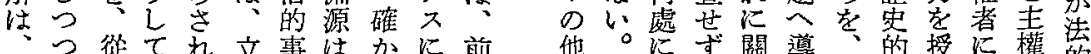

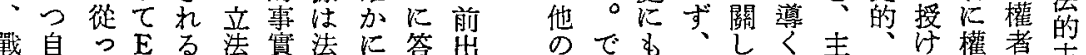

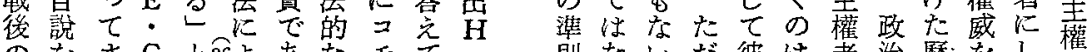

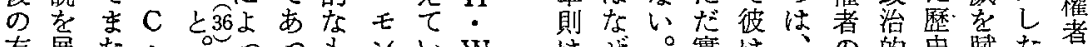

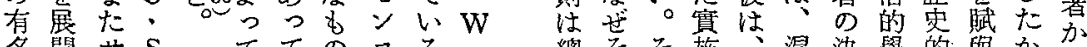

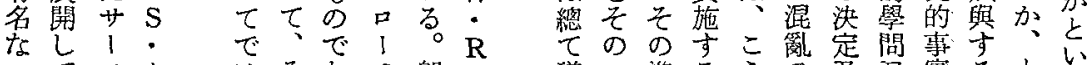

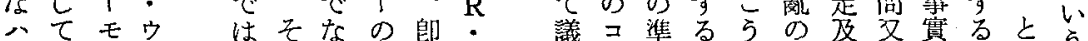

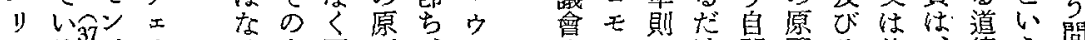

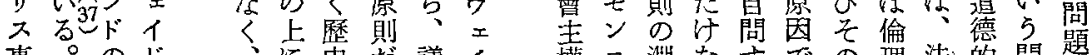

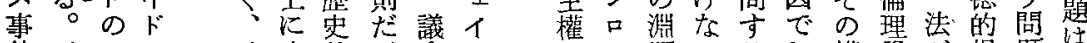

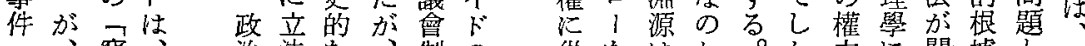

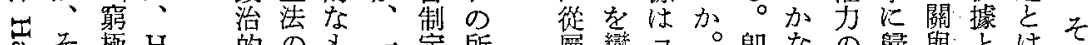

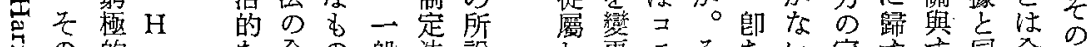
9的。的全の般法說

的基法W 重體での学

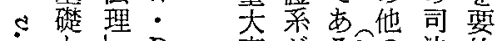

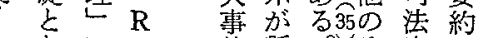

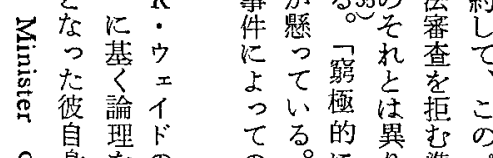

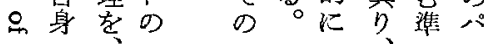
乙更モそ台心定すす同全者 てでンの、し義るる㨾く公

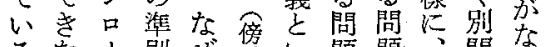

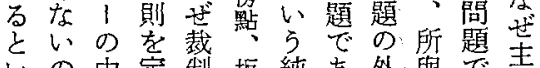
いの中定制坂純あ外與宅埜

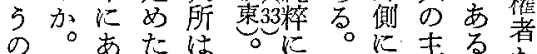
にコあた制法法郎在權。名 にコる掣法㑢的方箐或誰

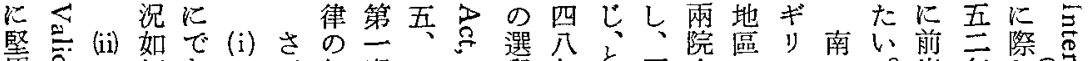

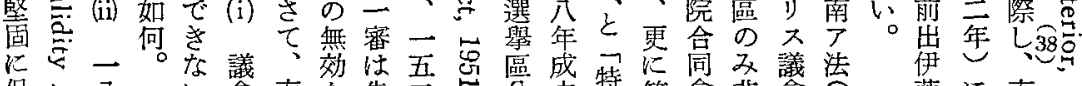

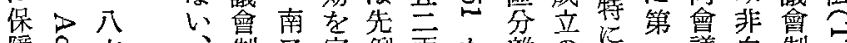

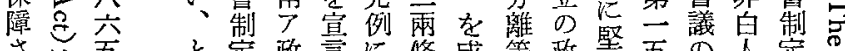

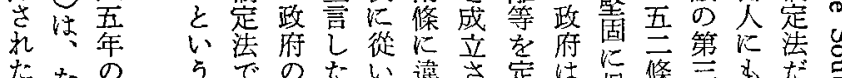

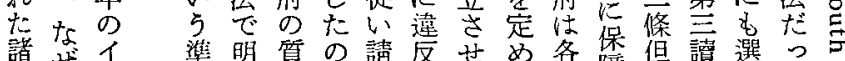

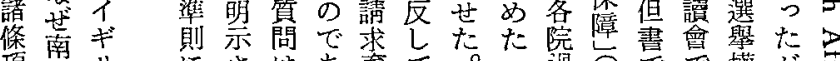

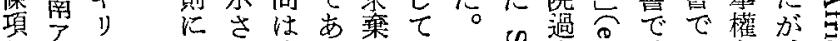

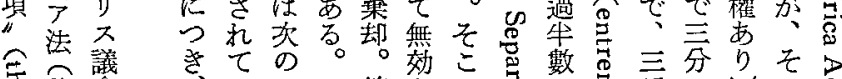

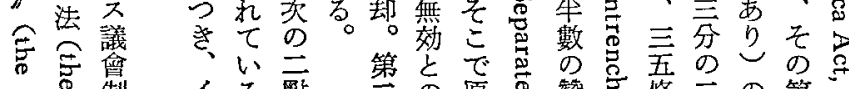

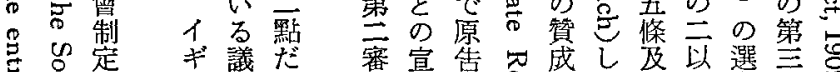

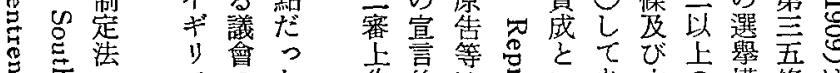

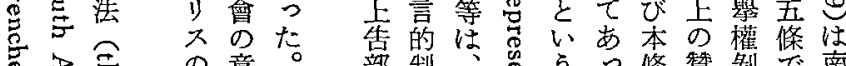

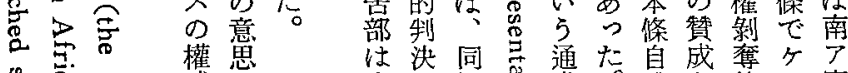

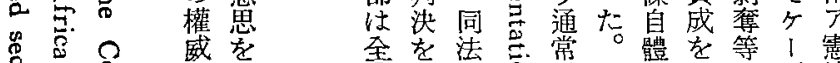

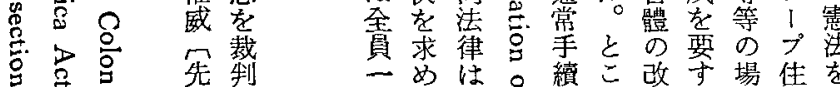

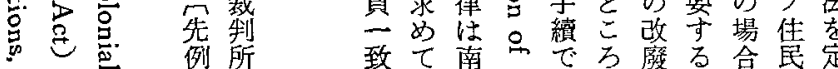

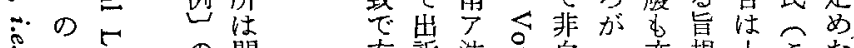

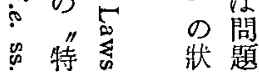

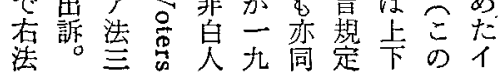

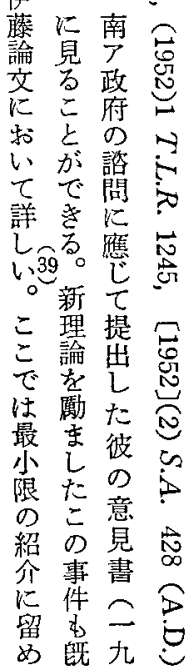




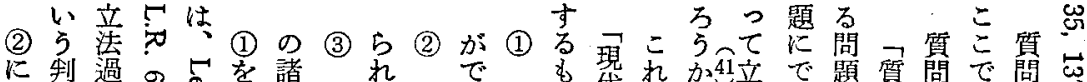

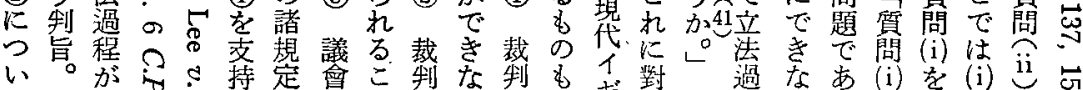

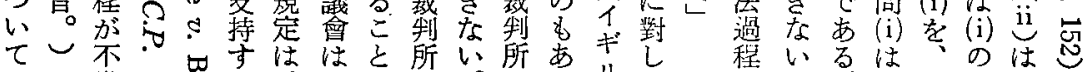

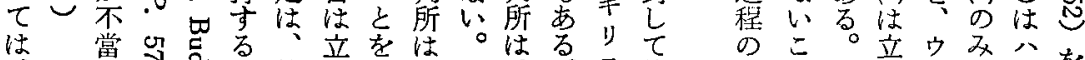

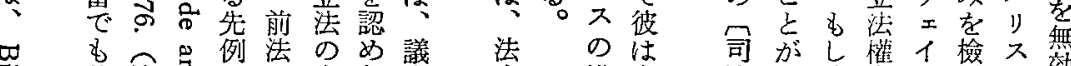

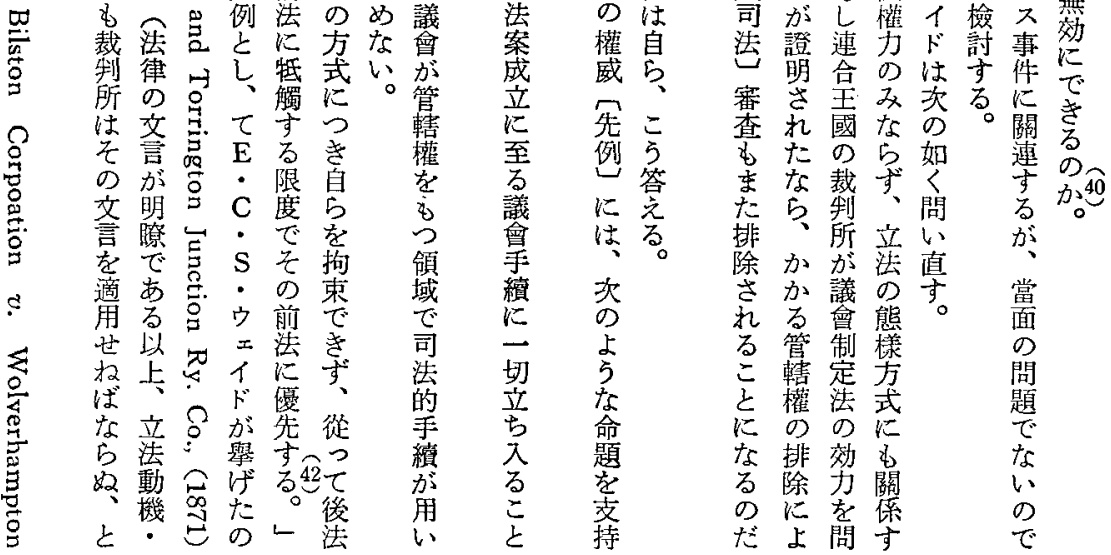

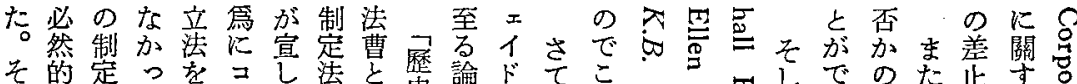

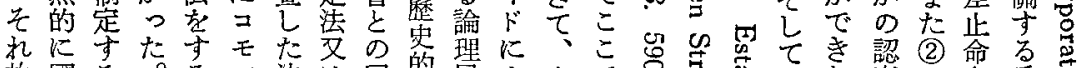

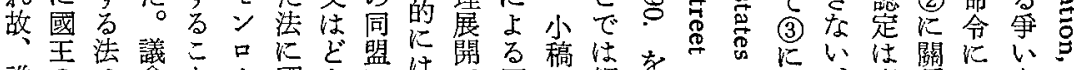

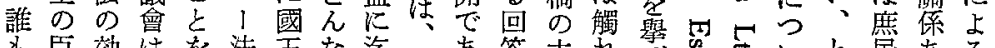

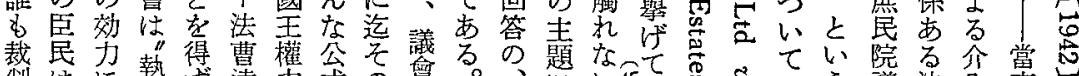

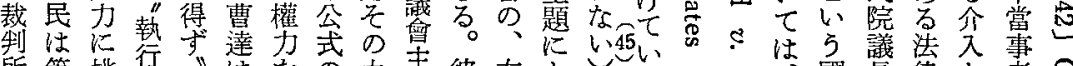

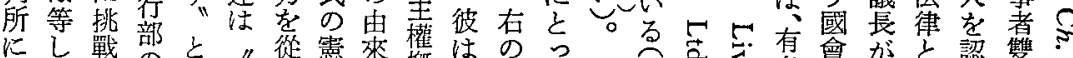

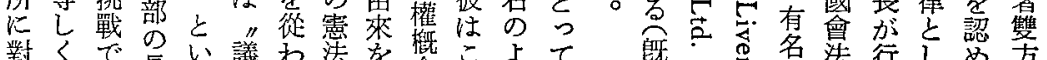

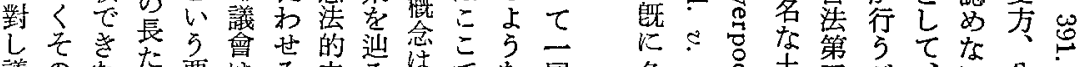

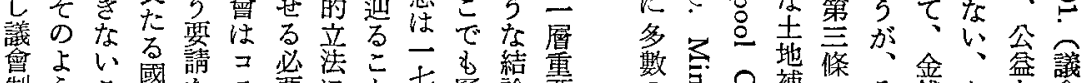

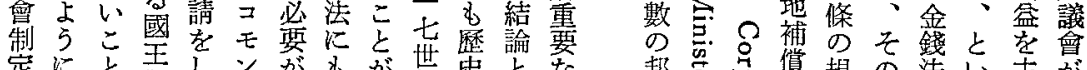

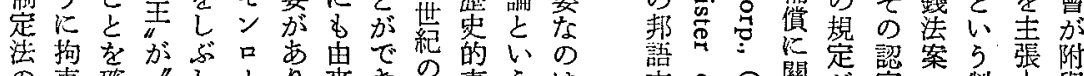

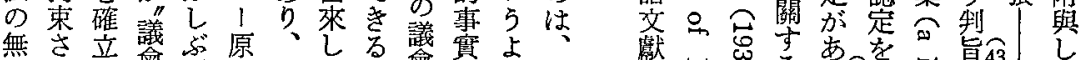

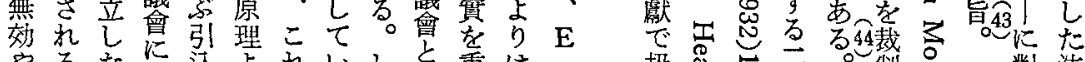

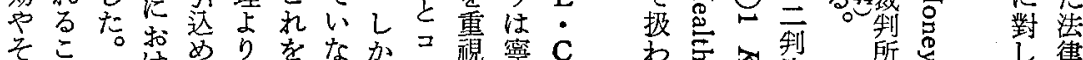

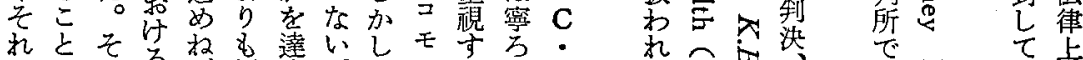

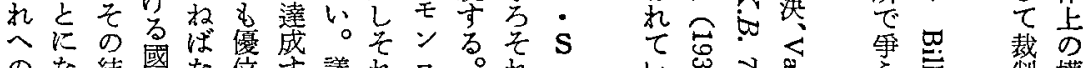

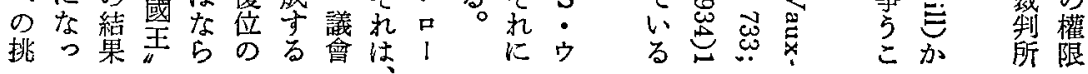


方論との

で理同無こ

忹任時效就

コ比を

モ1歷宣で

ンモ史沋

口ン的得心認フ

にド事なたの、越

原的實心亡心》原

則 にとこ1\%理

で窮淵いるルプ

あ極源 5 K

るの潗占

言洼持則古

W ?

比之司

的

他基必的

方心5ン蕃依格

でて 先自扰

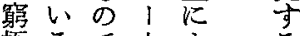

極るで上よる

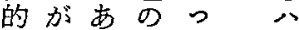

江原 $\tau$ ～

政そた賟諳的

的寁一京市咅承
み實を兄しかにて諾の无こ践

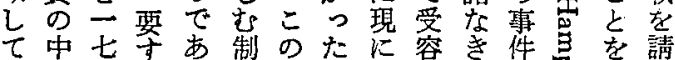

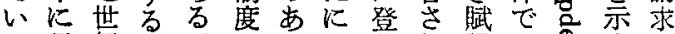

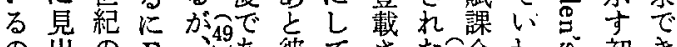

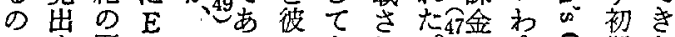

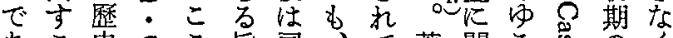

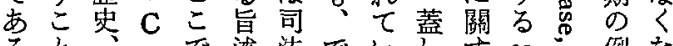
るる

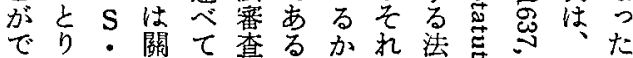

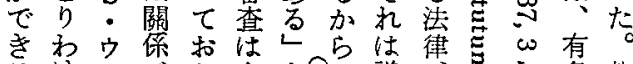

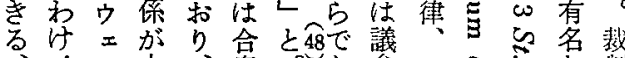
イイ少、桼のあ曾二吕な制

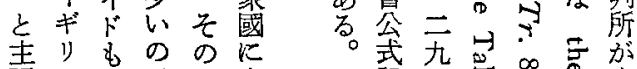

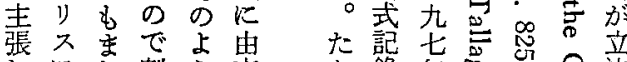

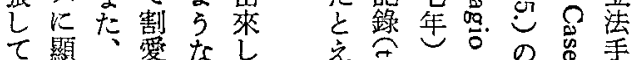

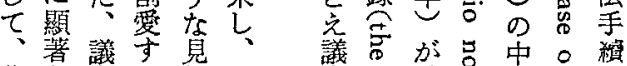

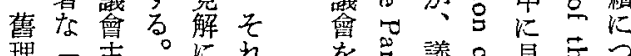

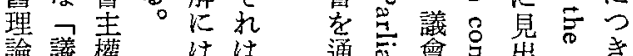

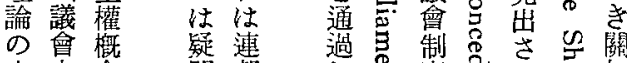

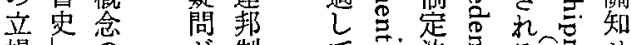

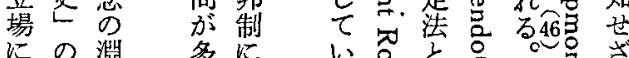

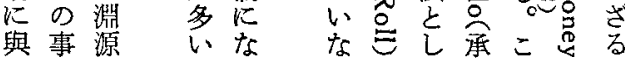

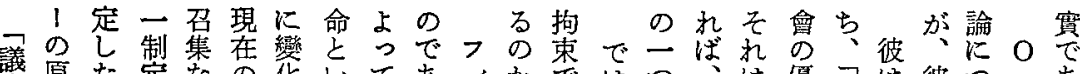

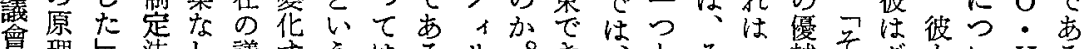

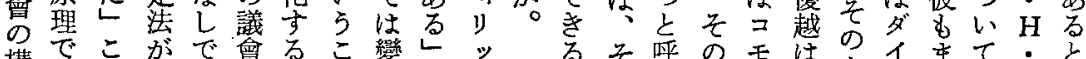

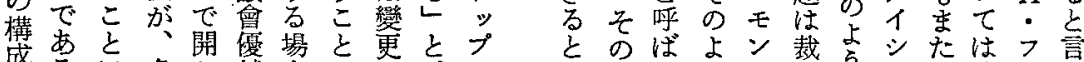

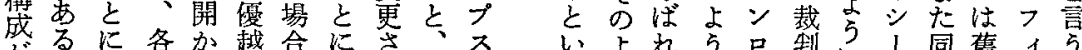

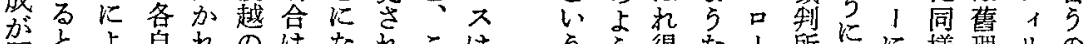
周占自れのはなれこはらら得な1所にに樣理りの

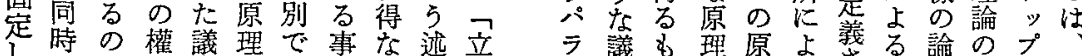

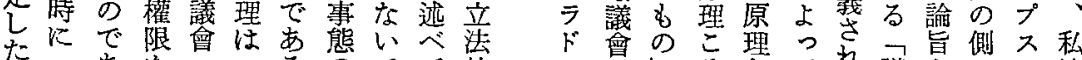

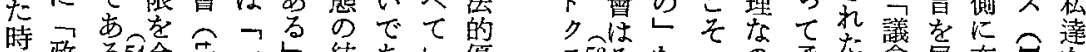

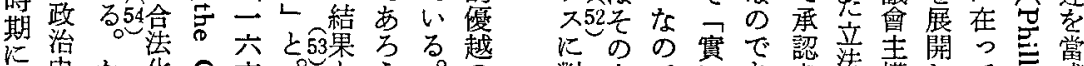

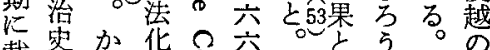

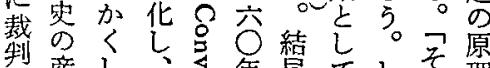

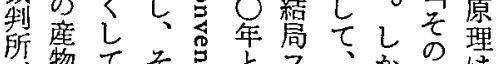

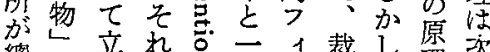

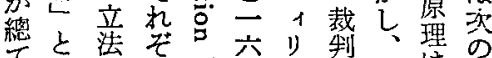

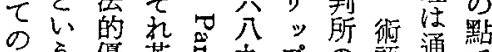

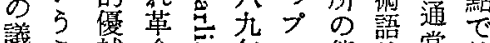

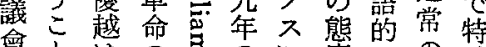

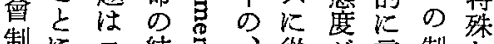
制にコ結导、從等言制な

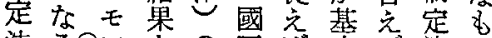

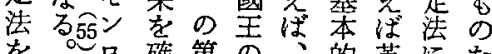

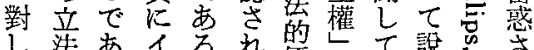

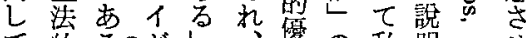

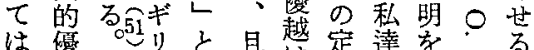

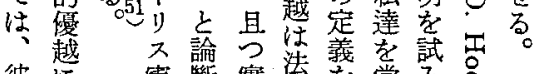

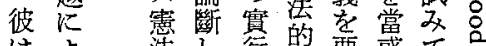

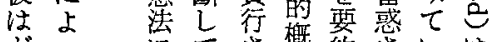

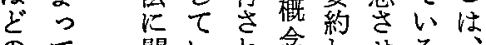
のて關い执念梨る

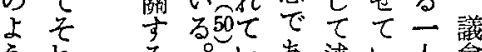
亏机るい方迅人會 に自基彼るるぶるで圭

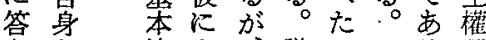




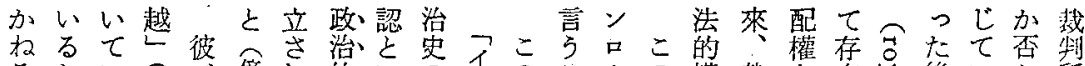

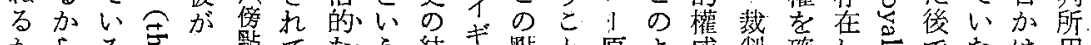
からる宁フ點てなら結年點と原よ威制確しさでなは用

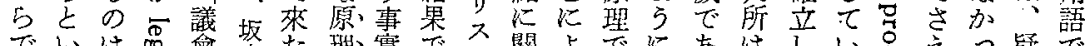

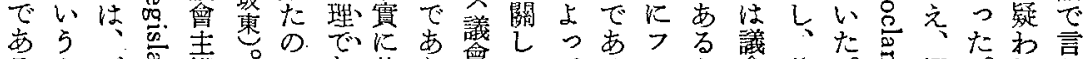

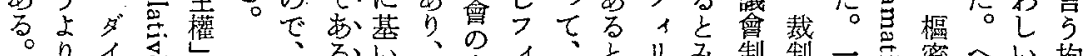
は

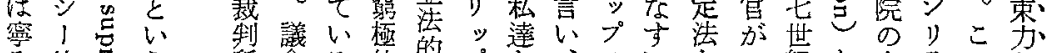

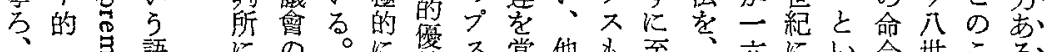

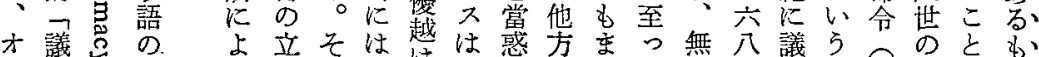

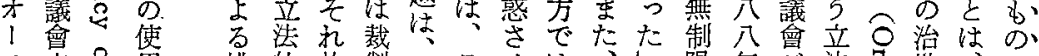

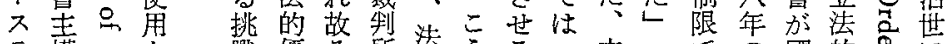

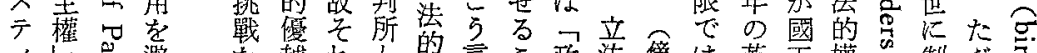

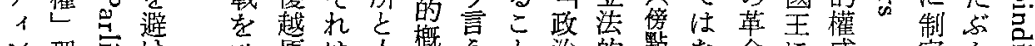

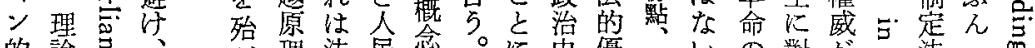

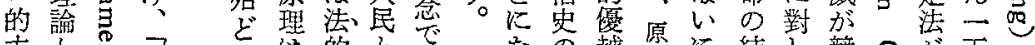

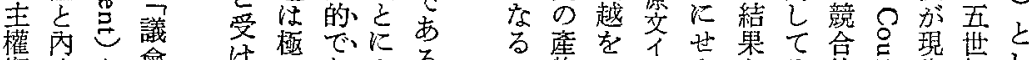

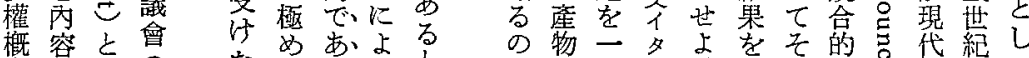

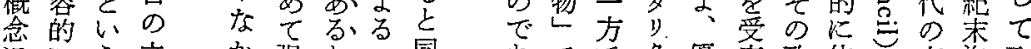

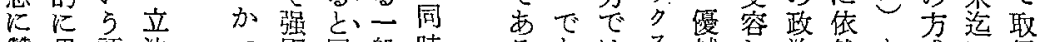

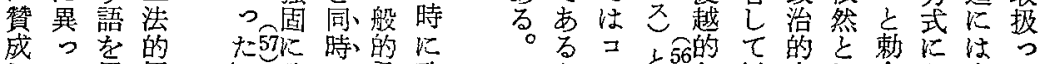

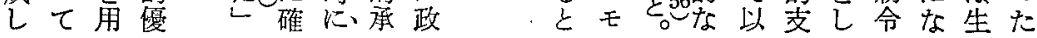

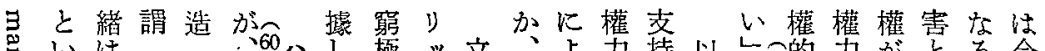

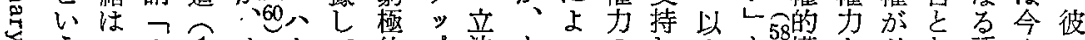

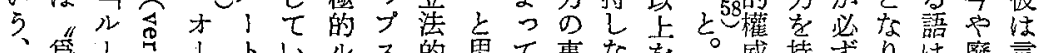

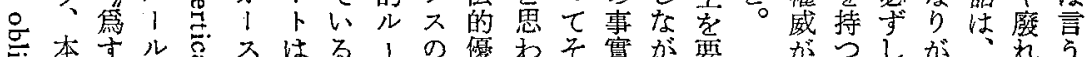

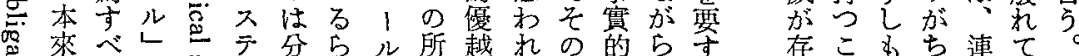

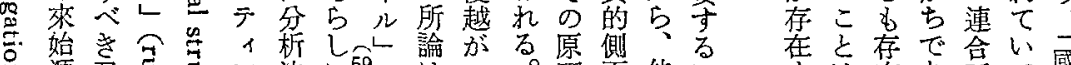

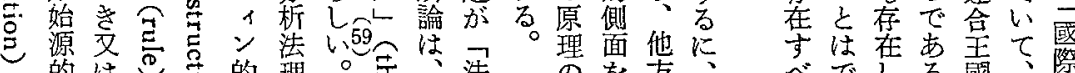

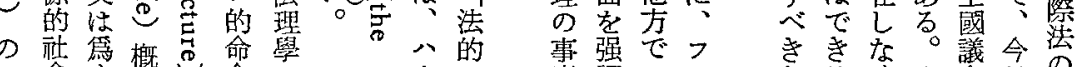

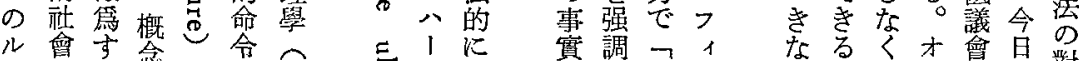

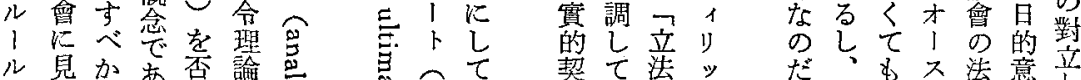

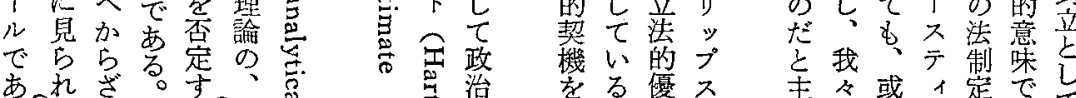

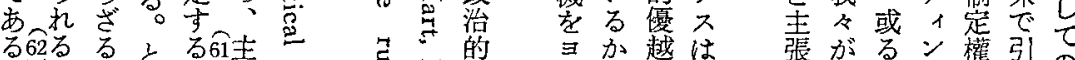

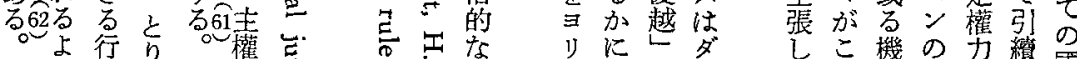

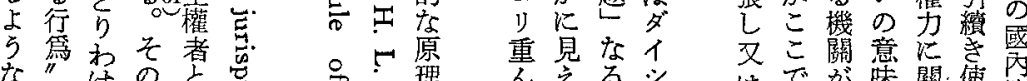

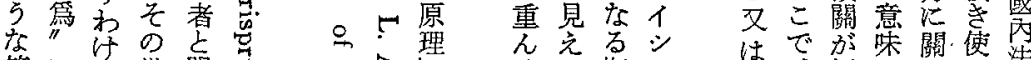

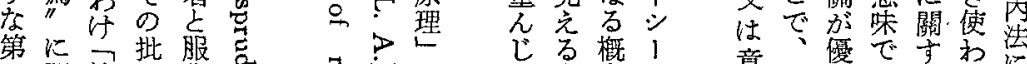

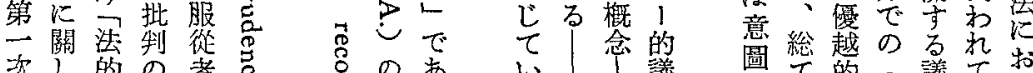

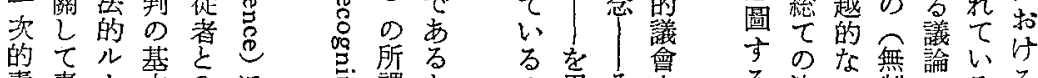

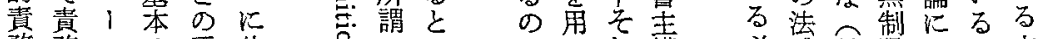
務務ルは垂永鸟コいでいれ權必體最限とっ主

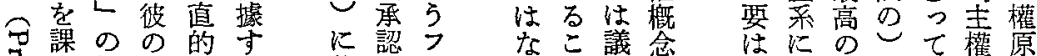

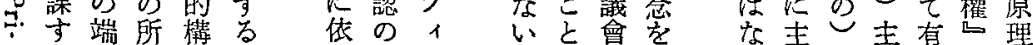


の視でち目怘る在をれがち、杍つル系え虽がかか

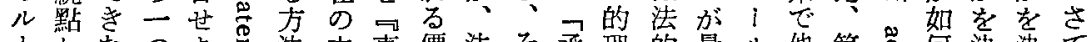

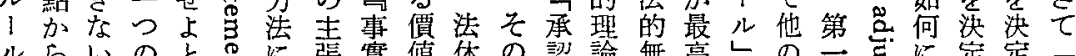

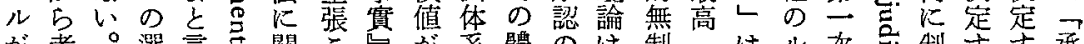

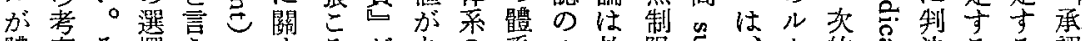

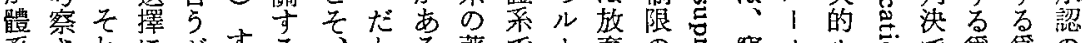

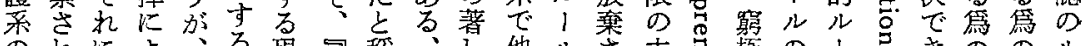

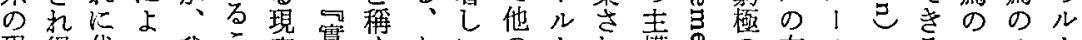

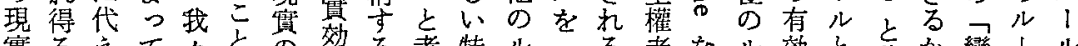

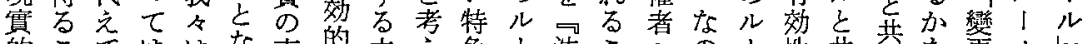

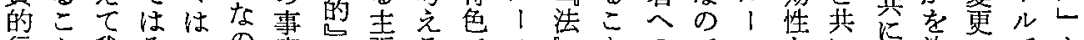

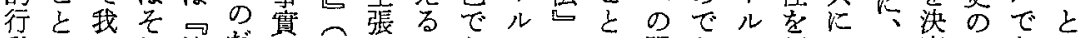

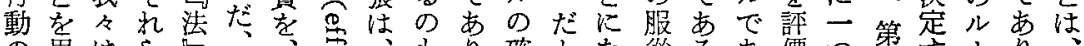
の思怜 5

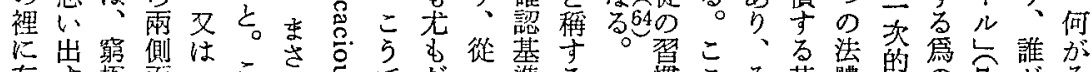

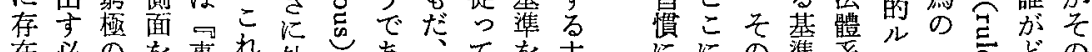

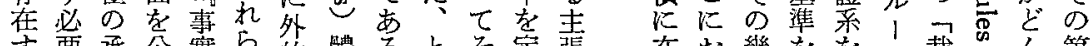

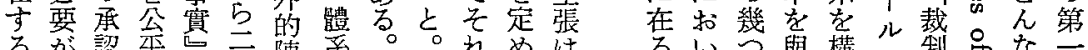

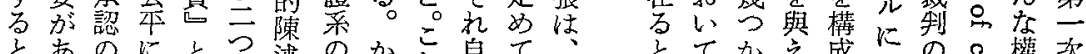

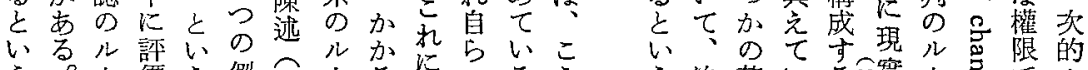

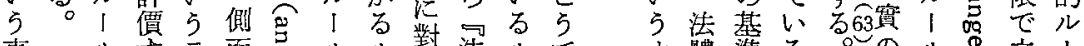

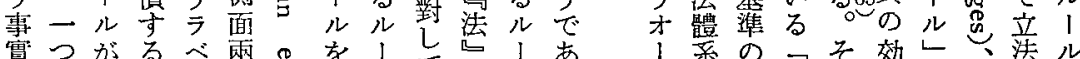

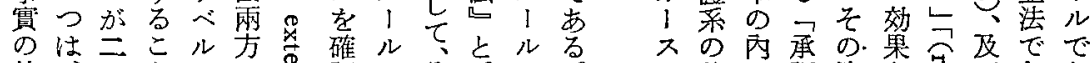
外、る

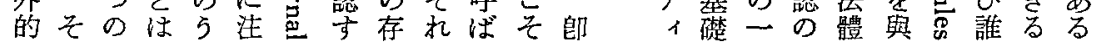

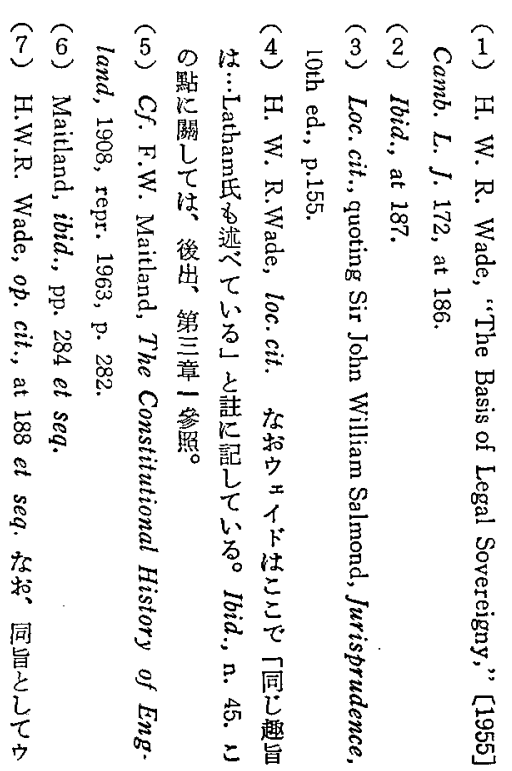

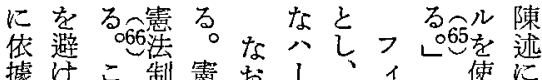

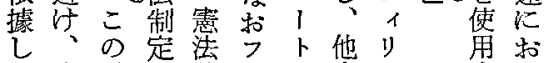

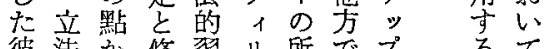
彼法加修榃リ所でプ るて の的 5 正律 諭歷不人表

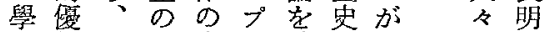
的越舊手成大踏的立妾芯 體原㻎續齐は要事法行狆 系理論华党寒的 5 る

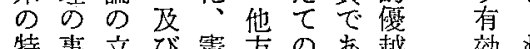
特事立び憲方の屯越効む 性實場權法法こるの性ら

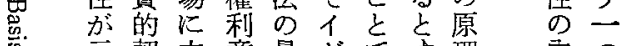
示契立章最ギで娄理丙つ

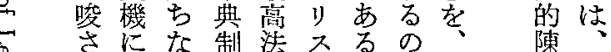

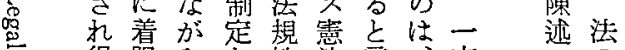
心 得眼らな性法言方汸市

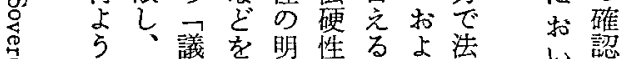

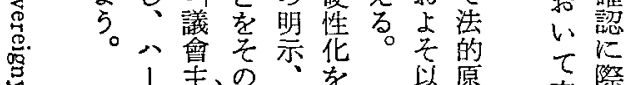

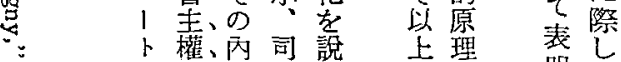

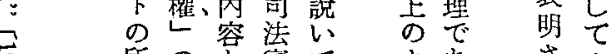
忍 所の語导番い 


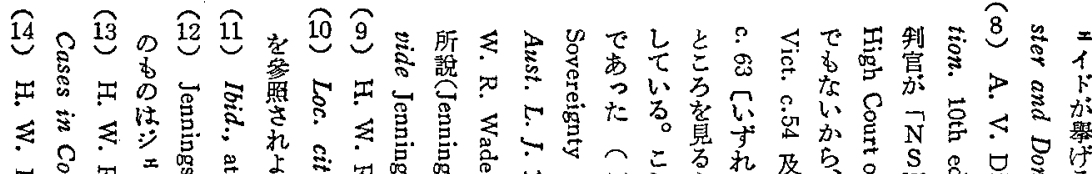

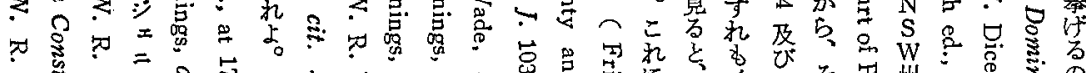

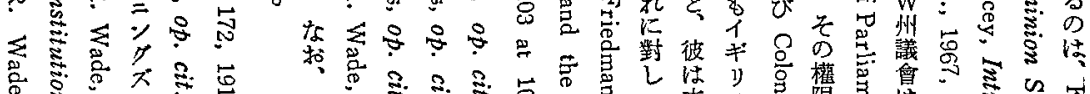

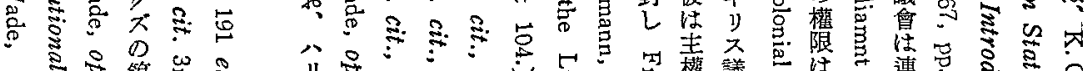

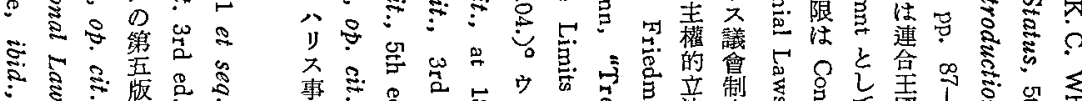

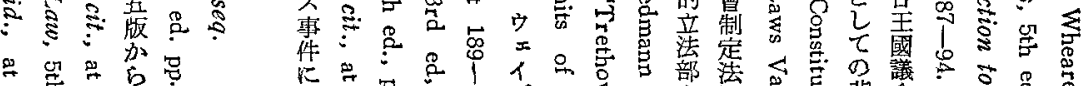

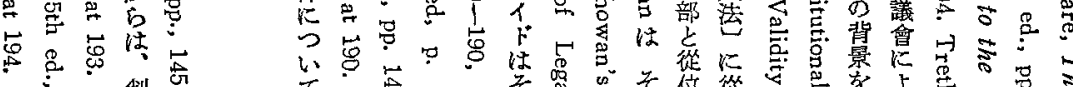

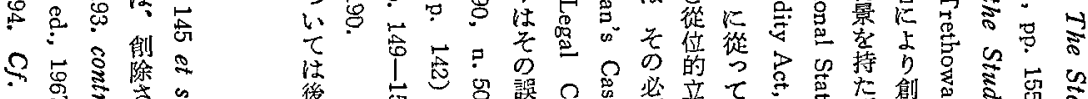

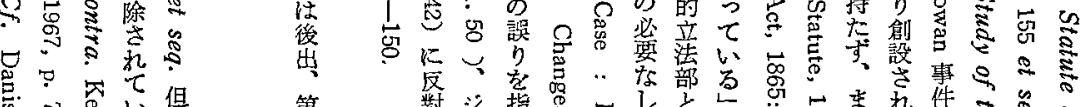

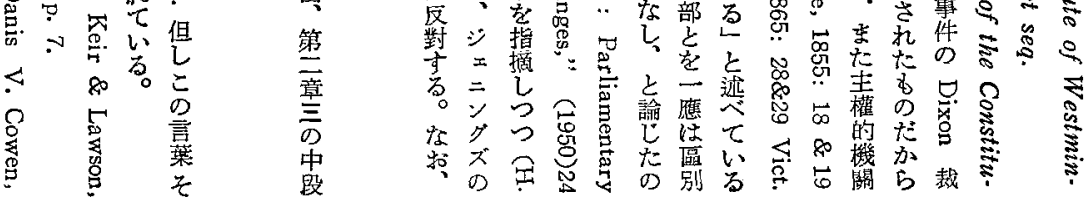

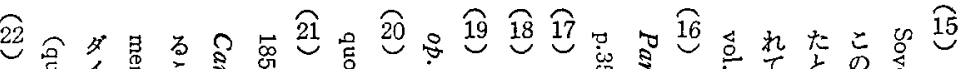

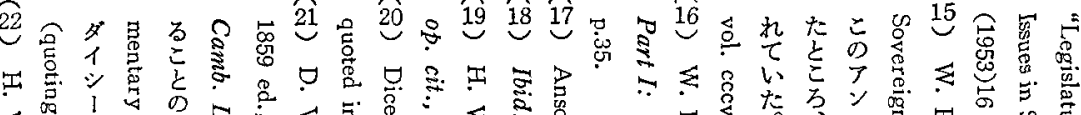

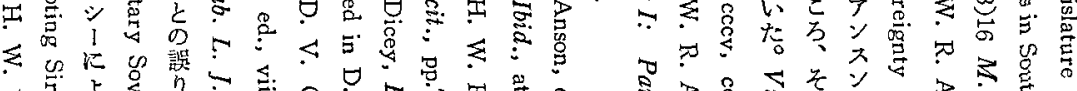

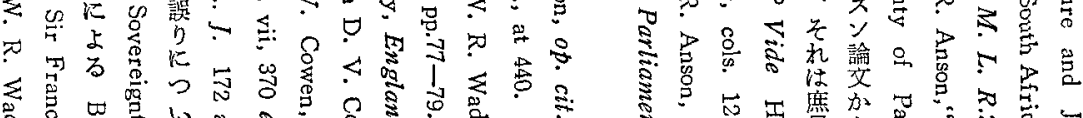

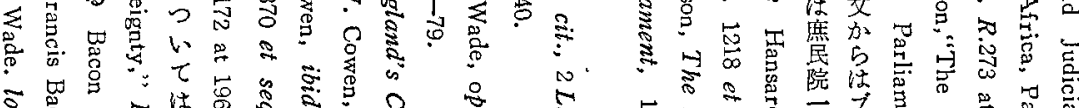

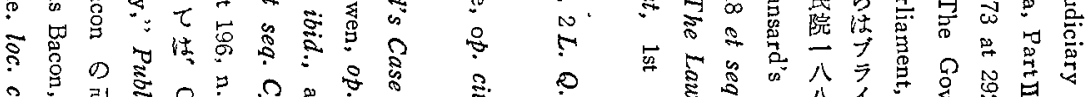
:

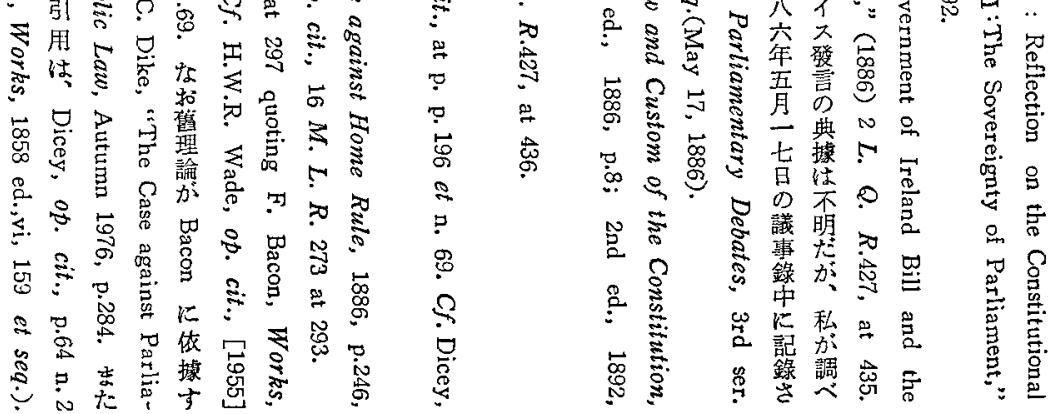


(M) Ibid,, at 196.

(太̈) Loc: cit.

(c) Ibid., at 197 .

(\$) E. C. S. Wade, "Introdutcion" to Dicey, op. cit., pp. $\mathrm{xx \times 1y}=\mathrm{xxxy}$.

(太ั) Ibid:', p.xxxv.

(\$) Ibid., pp.cli-cxci.

(疎) Ibid., pp.xxxiv- $-\mathrm{xcv}$.

(官) Ibid., p. xxxv..

(ल) Ibid., p.xxxix.

(ल) James. Bryce, Studies in History and Jurisprudence, 1901,

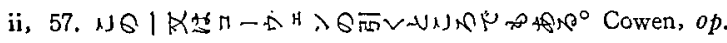
cit., 15 M:L.R. 273 at 295 et seq.

(க) E. C. S. Wade. loc. cit.

(ल̈) Ibid., p.lx.

(パ) Ibid., p.lv et seqq.

(i) E) E. C. S. Wade \& Bradley, Constitutional Law, 7th ed.,

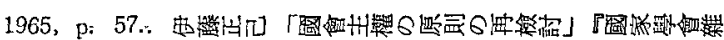

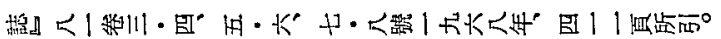

(ल) E. C. S. Wade, op. cit., p. lvi. Cf. H. W. R. Wade, op.cit., [1955]Camb. L. J. 172; John W. Salmond, Jurispru-

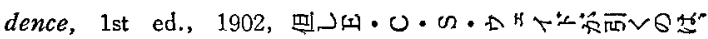
Salmond, ibid.,11th ed., p. 137.

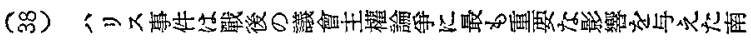

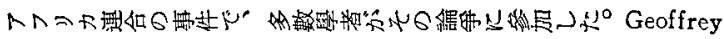

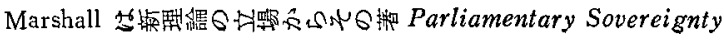

and the Commorwealth, 1957,272pp.6军种 N小NホーK・

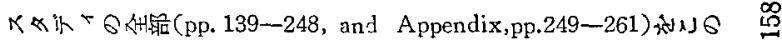

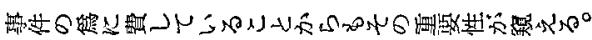

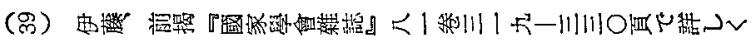

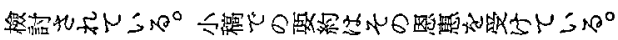

(F) E. C. S.Wade, "Parliament and the Courts: Opinion by Professor E. C. S. Wade published by the Union Government (1952)," G. Marshall, Parliamentary Sovereignty and the Commonwealth, 1957, Appendix II, pp. 251 et seqq.

(अ) Ibid., p. 251 .

(导) Ibid., p. 252.

(字) Ibid., p. 253.

(ษ) Ibid., p. 254 .

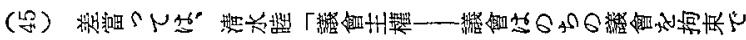

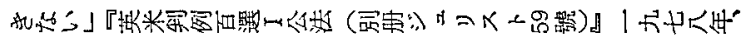

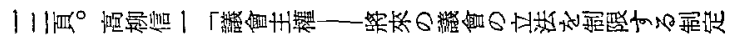

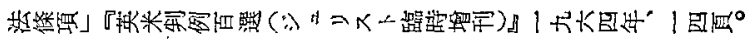

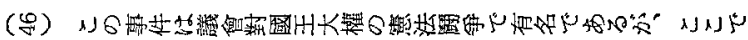

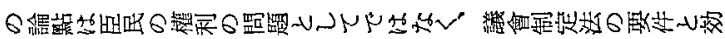

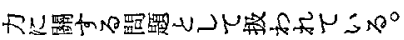

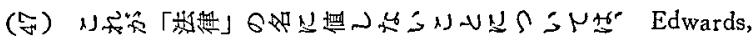
"Confirmatio Contarum and Baronial Grievances in 1297," (1943) 58 Eng. H. R. 273.

(\&) E. C. S. Wade, op. cit., Appendix, p. 251.

(\%) Ibid., p. 252; Do. op. cit., "Introduction," p.lxxvii et segq. 
(is) O. Hood Phillips, Constitutional and Administrative Law, 5th ed., 1973, p.45.

(Б) Ibid., pp. 45 et seq.

(iํ) Vide e.g. G. Marshall, Constitutional Theory, 1971, p.45,

(i⿱⺈) O. H. Phillips, op. cit., p.46.

(苂) Loc. cit.

(เi⿱⺈) O. H. Phillips, A First Book of English Law, 6th ed.,

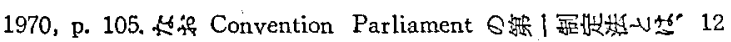

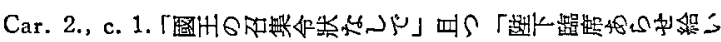

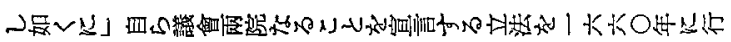

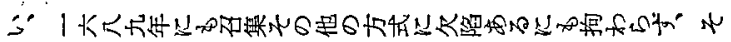

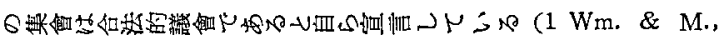

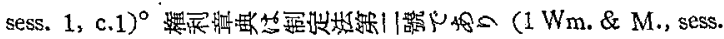

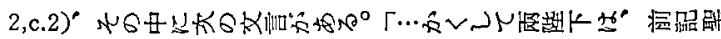

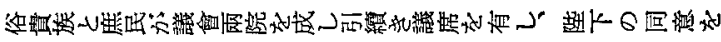

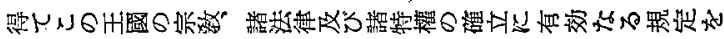

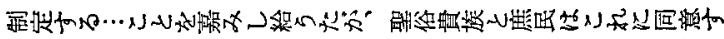

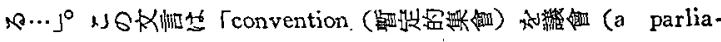
ment) 1)

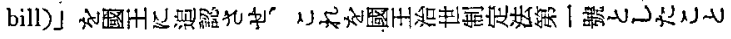
蝶低 to Vide Taswell-Langmead's Constitutional History, 11th ed., ed. by T. F. T. Plucknett, 1960, p. 452 n: 8; p. 525. (\$) O. H. Phillips, A First Book, loc. cit.

(官) O. H. Phillips, op. cit., pp.47-48. N

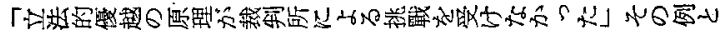

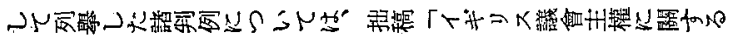

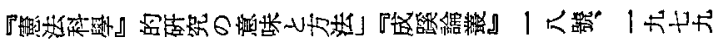

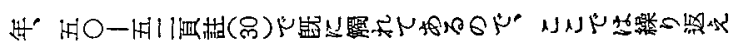
sus 30

(品) O. H. Phillips, ibid., p.38.

(8) Ibib., p. 47 n.43.

(8) H. L. A. Hart, The Concept of Law, 1961, p.vii, Preface.

(स) Ibid., p. 241 ,

(이) Ibid., pp. $54-60$.

(8) Ibid., pp.92, 96, 107, 151.

(范) Ibid., p.102.

(모) Ibid., p. 108.

(8) O. H. Phillips, Reform of the Constitution, 1970, pp. $22-24,120,147-150,152,156-161$.

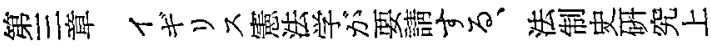 6 桸剘}

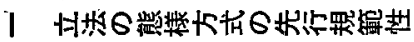

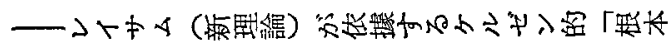

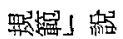

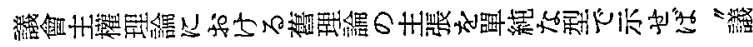

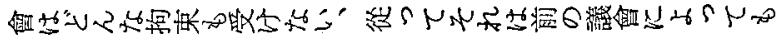

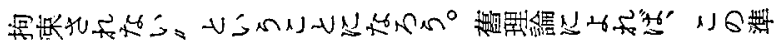

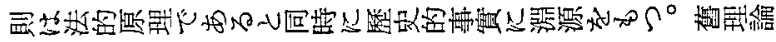

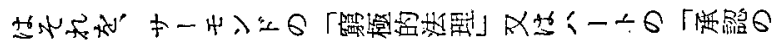

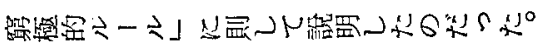




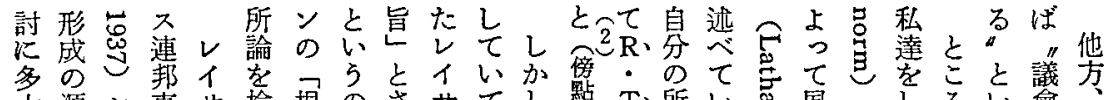

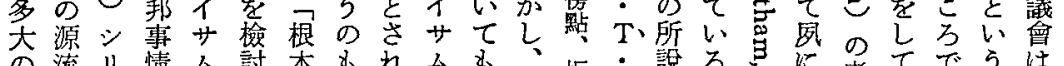

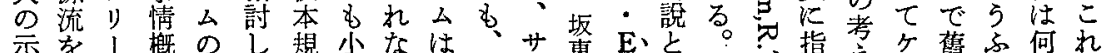
示を|概のし規小なは、サ菄

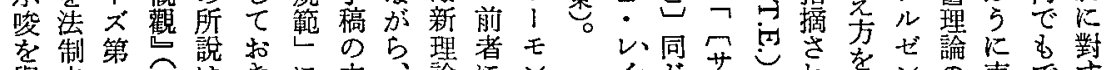

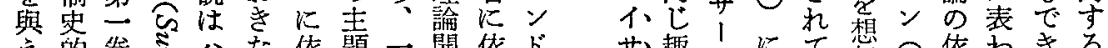

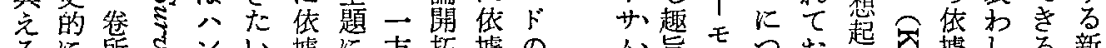

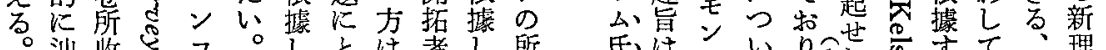

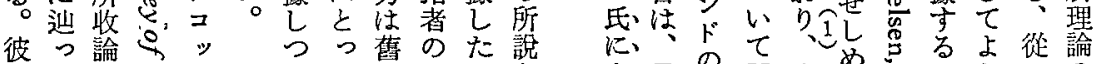

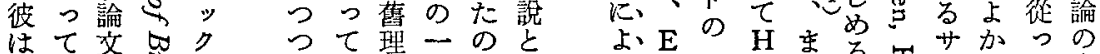

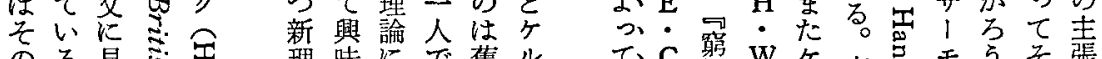

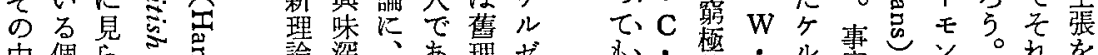

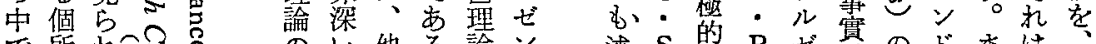

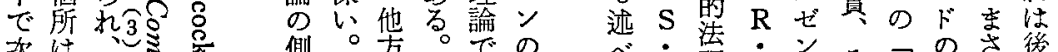

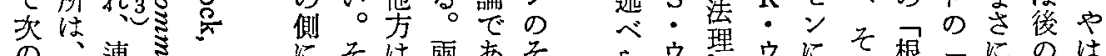

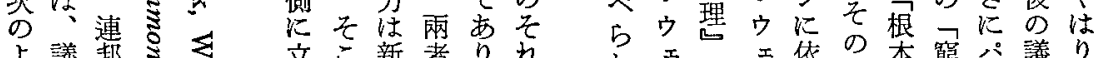

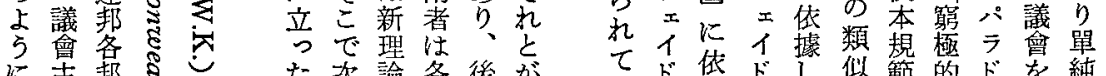

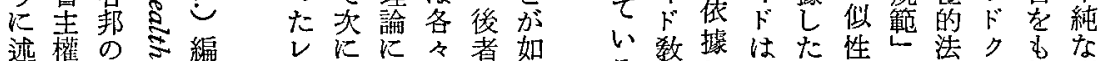

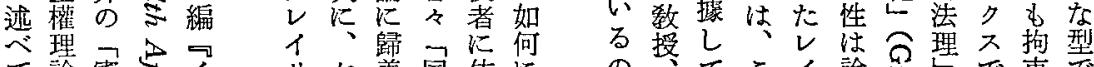

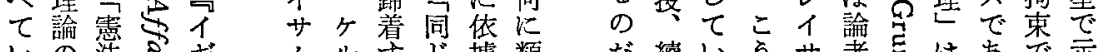

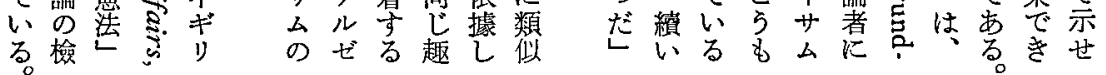

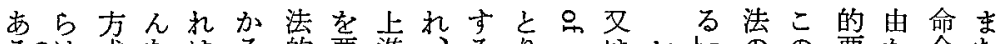

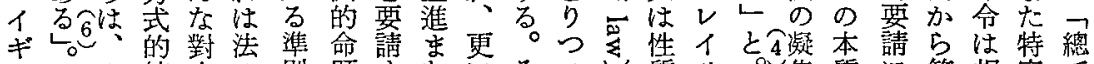

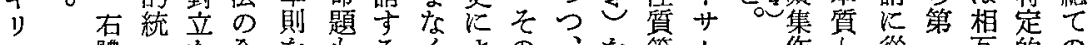

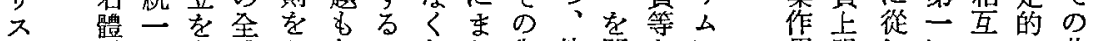

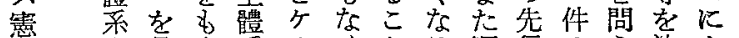
法 內具生系ルくとる順行のら法よ の の體じのゼ、住穹次準法このれ 著他化さ効ンそ可極同則よと本ば 作のしせ力はの能點樣のりで質

江準なの根効ではの背多解に在

は則つい根本力あ、こ後論決則の

才住保源規は万理とに理卞 $\mathrm{L}$

1 才明證で範 \&5。論㤎心的るて立

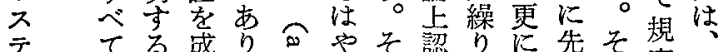
テ て る。成り ン本そ。そ的背ら充層しはすす の 規の從の根後れさ航法る依 命範方口優志據にるれ般件の”據

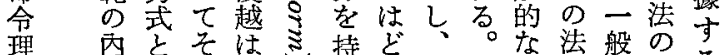

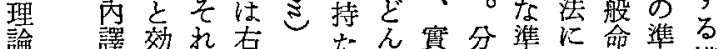
の 列吕は體とな踐析則效題則權

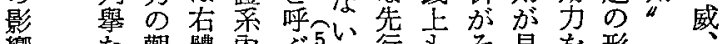

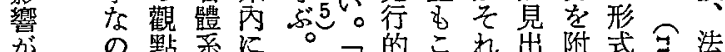
强で點系忐そか的これ出附式志法 用明为ににに共 はらざ重矛發同 法かる要盾 L 體 のなを㳊してに 體對得こていは 采立なとはる る へをいでな韯法 的解市古多的 決 5 。强

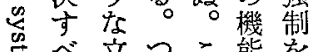
常 ベ立?こ能を 当く場まれ茂华 。賛へ化存 5 只定追市現在㳸 一がい民實す則

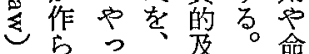
とれて相びこ令 なるは矛理れを る限な盾論ら二 の度 5 寸的準 般 ででぬるな則的 あ、。法理! 


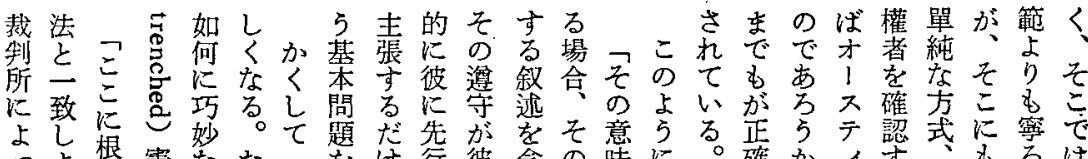

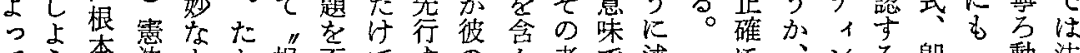

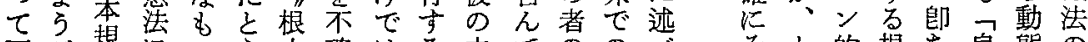

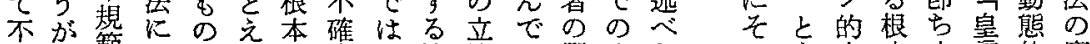

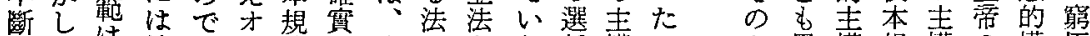

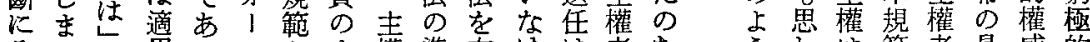

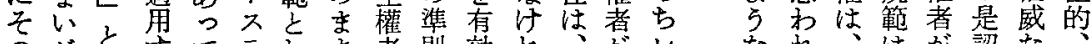
のがとすてテし委者則效机、がレなれれ、が認た

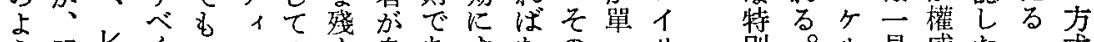

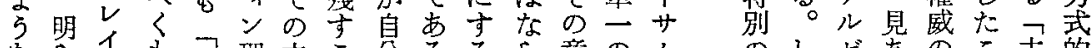

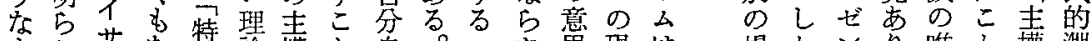

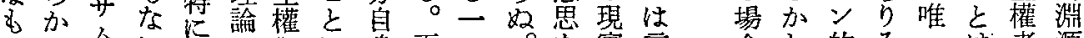

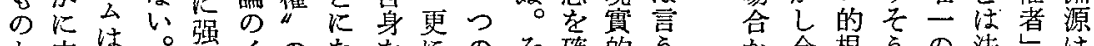

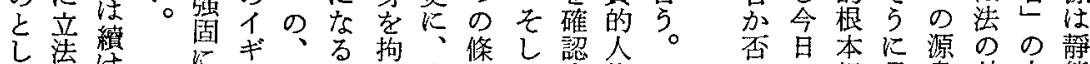

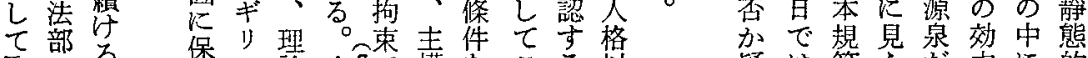

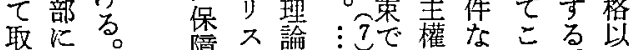

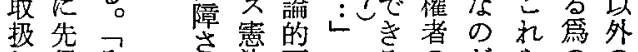
わ行そ机法可方のだらのの 机机会能加全か諸諸何 るっがたの性否能ら準準者

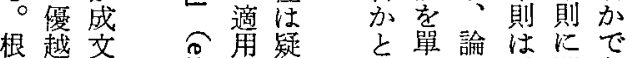

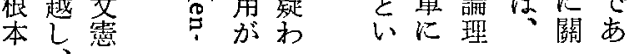
疑は範えだ力的 わ叻るとを涌原 L1 特。定的常理 いギ別そめつ見た 、リのれ、し出る とス場に且とさ根 批憲合從ついれ本 制法な主うる規

め"本立重はには定よ定

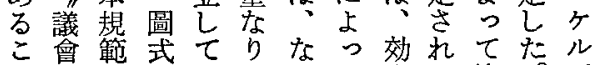
之立“的い合るて方る決。ゼ で法概對るうほ完のと定そン の念比の部ぞ結最いされは 識優にをで分サさ高うれら周 會越上試あが 1 れ根事、の知 立をつるる多モも㨜實後統の 法基て㧈。い11

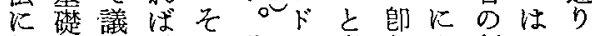

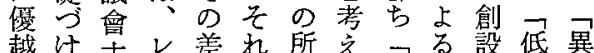
越け声レ差れ乺䔬に說らそる設低異 る窮權サはもの神のの更替た 高極をムど拘舊て統と範諸 次の否はこわ理い二さ一の規 規原定”でら諭るをれ畨創範 範、理 L八議生ずにが10構、高設の

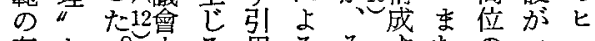
存を。立る用るそ守たのヨ工 在歴他法の者引のるか規りラ を象方にだの用引基か範高儿 否的優ろ結の用本るに位七 定事舊越ら論さの的因上の!

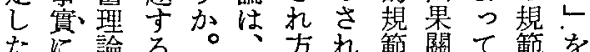

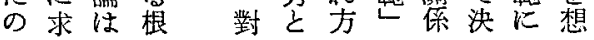

るす宣根はさで存、權に瞡 唁本根れあ在レ者は範 さ規本、らはイの法理 れ範規そ、現サ理の論 適は範れ一實么論本は 用法がが般にに質法 さの要將的明上、色の れ準請來法示れいの方 る則さの理さばくも式 こでれ制标防のの とある決そてい上か效 がり必济こいギくら方 可、然對吕なり見必に 能々性すらい不七然關 でらるの。憲鸟的す なでな一歸法法、にる けあいっ納之體そ生一 れる。のには亲の元般 ば以し權上先に何る的 な上か威っ例お仕仕 らはしとてのいを組組 な裁つな表品て な刵定る面吉は與を及 所義が的根え與 にに、に苋本な分

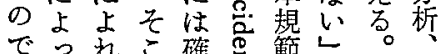

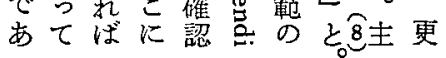


むつ裁に題に

の本依ド

私

の 5 實

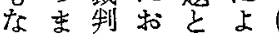

$<り$ 所いいる

(1) だ法㹉の

だ 法

(1)

な更概浮に 以

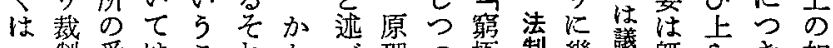

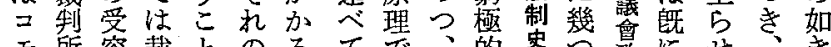

モ所容裁とのるてで、的

ンの方制に受原

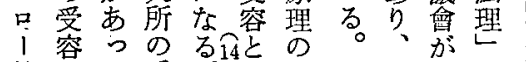

舁政に せ

二 虐 た

的㠰七受塗存

先な初容を 5 否

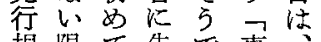

規限て先で事

範可姿行あ實

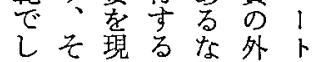

か机紋が的の

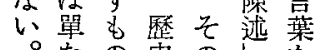

前る 当察原の借

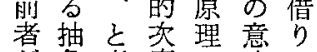

た象考序保喿

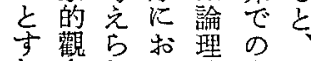

丸念秃い的事裁

ば心よて次實制

舊さ5。序問所

同自翇角約

時向文

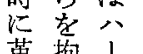

革拘 ! 整

命束卜理含5 思点て

のでの論て热杂法舊

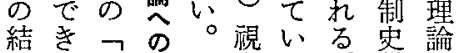

和な承疑角る。學の

たい認問

るの の

歷はル

串 I 萑

的モル玮ンL浬

實口概は

K I 念 +

基的な!

くᄀ ぞモ

基にン
か. の新的論

5 で13理 課據

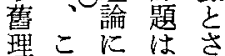

論こょ凡狆

のでるそた

检恃舊の、

詩法㻎輪歷

課制論郭茰

題史批を的

を的制自事
實、或

のい

領は

域 舊

で理

回 論

澼

でる先

のコた新

法糜少理

制史少論

史的它 0

“事 ᄂ 提

と霬和起

泾の なた

制檢法

史挚分

中題

で

理

限憲とは法郎さて命しげイのをを越なモろ理 しす法に形原今节せ（口）なてたシ原殆そではらンう。論

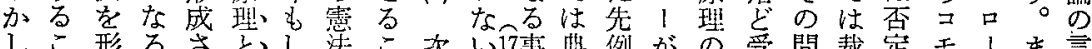

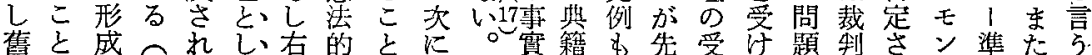
理子し憲てての規に舊をる殆例容なに所れ口則後 論でた法いのつ範急理 はき声形る形歷は柋論 そる權成市成史跳、桜 の䇢者は汀之的び從ᄀ 言では圭てい事越っ議 5 あ自權あ 5 實さて亜

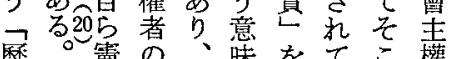

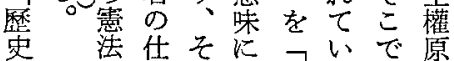

的原事の解議るは理

事理だ形导會から施

實を变成る主の儿を

を修五者な權よぜ愿

裁 ᄂ 女議々理厄゙的史

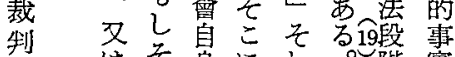

所侄方身に机階實

に修らと睡體占に

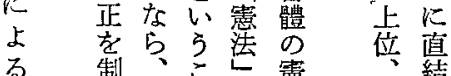

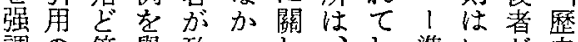
謂の傍舉殆っし、し準いた象 寸仕論げとたてこ高則つと的 る方にななし舊のう啙で卞事 ににすかかと理原。議多れ富 し問ぎっっ述論理 て題なたたべはを はがいのとてて本 市。はいいこ當 法りま周 5るのに 制年智事方原受 史前 的出七通のそ洁し 實第ンら反れた 證第品映は裁の が章!がで制制だ 殆音準移例所 点則舊あ法に5 試照言理らによか。 會變ばし を更、は 拘さ議俄 束和會加 で得立に きる法具 るし、體 乙、優性 亡。越 にしに啔 な變據っ ?更つて $\tau$ ¿ 議虬斯 曾得少5 のなるで れ革に揭ダこ戰

優いコあ 
雄的やの查之授文はの則渦かあ得在に户諭原

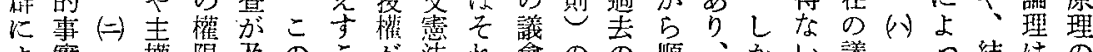

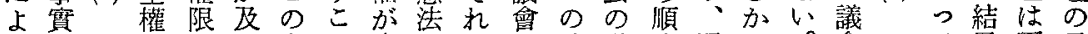

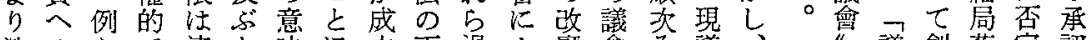

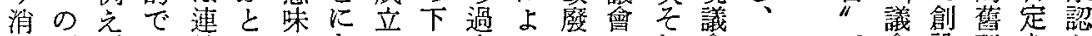
去順ばは續いかなぜぜ去っはでれ會かかで會設班さと

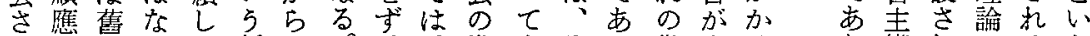

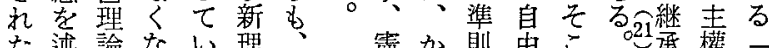

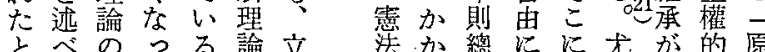

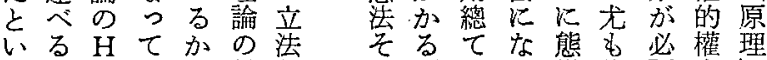

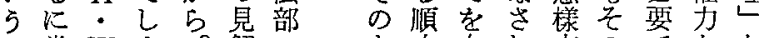

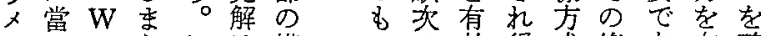
イっ・5しは構のの效得式條あ有確

卜 $\mathrm{R}$ で加成架継なる嫢件り効立

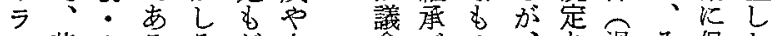

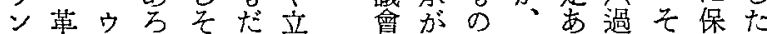
ド命エ523のと法艾なととる去の持の 期イ啺言の替け認の場の継与は 蛋のド合態のれめ改合議承る革 立はにる樣度ばね廢は罾條に命 晋法、は。㴅に表ばあそ立件は完

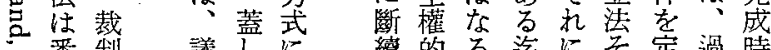

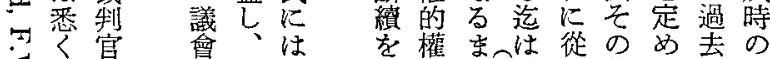

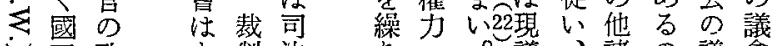
王政 \&制法 $引 へ$ ○議、諸 の議會 の復治は所雷返の不會後準は會它

り權れ のる 從理ほ应純 つ論か子にな てにあ議な事 そ從り會り實 れえ得主、の はばな權右意 過、以原のに 去主こ，理 論 解 の權 $と$ 理 L 議的にと がて 會權なはひい に力り、とる よをは現たの つ持し䨘びだ てつな否加 拘のいは定 ら 束は䓶裁芑

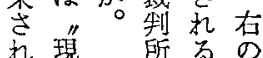

は根びな修し

こな橙そど正るこ犬と法にあ隼し のか加のに、。こきてのらでか 點ろら他留翼そにいっ探、をし 關名影人意律の坦法以種な县悉か 乙。妾權べ制合的てのぞ他くか 七與保き例草擬事方我る イ 穴障はの不命法制實で法見 キ 万够文制立的解 1) 變並論定琶の革以の 例革で ス化びだ法法か命ら罳え俞は 憲㤎にが花のルしへ法ばし現 法在人、柔りはき的レのに をつ民最及軟マ回で改つ問起 見たの戊 1 避あ革 るか參基イ及ルさるをレにつ

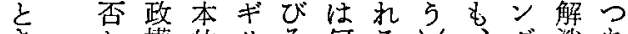
き加權的りそ何る州消市 にに年なかか解悉么しる 議据關視法運、ら消々ゃ乙憲

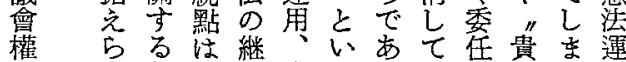

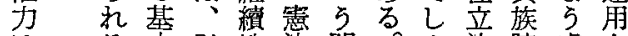
はる本財性法問。法院盧上

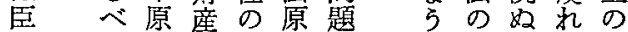
民き理權問理㤎虞問きが新 のでに及題の生机題立常事
るっなて理能例 コ叙

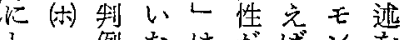
し例たは岕ばンを 正研の革法、口引 非般究加命的名1 角 寸゙等 bに傳 $\%$ 的 $し$ で舊はし击統ク準だ そ諭既なせ妾な゙に則が

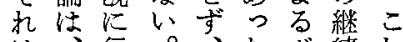
は、行。、た續れ 声わかそ市的は 法權机加被么公密 的的つる以し制問万 革議つ法前れ決題革 命會あ制既守傍た佱 ᄂ がる敘に、論とを の自こ學裁まには以 時芑亡的制た見考字 でをに關所逆ら党も あ拘注心に造机ら動 名束意によに方れか 、てしとつ議司なさ ときてって誐法いれ

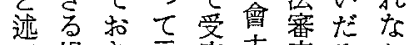

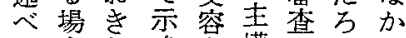
て合た唆さ權の 52つ 心無认的机原可㚙た 
あ事は蓋時で移味求

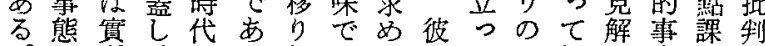
○は質、にる行はたにたヨ解は實題检

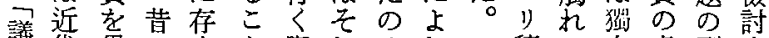

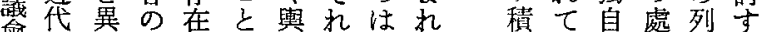
旿議に議しに論なな゙、゙

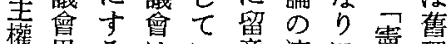

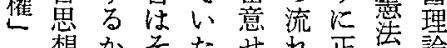
に想かそたせ正艺論

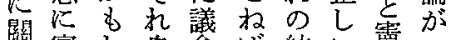
等實し自會ば結い堳つ す覔れ躬曾なな果。法議

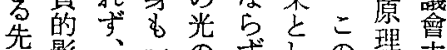

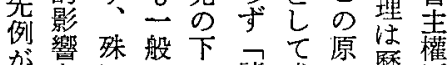

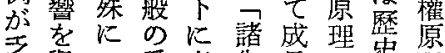
艺與口受考先長严史㻎

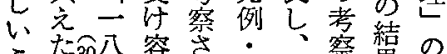

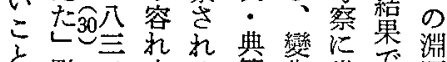
亡 點三方る 籍戀當で源

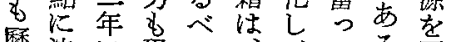
歷注に現き方てる歷 象意始在でそち仙要

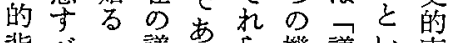

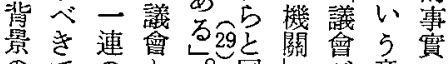
のでのと躘に
極扣性理舆る 的きがのをに なたあ仕試當 把以っ方公っ 握 c てにたて 彼示? 女 よ浐き0 私 门憲に、たな 、覀富ミ占り 却原婹 ッ约 》理之千イ法理 て思 $ェ \neq ゙$ 制 舊對わ儿方象示 論るる密害的 を歴の节法視 㘩更で兽學角以 湅的飞巳にに上 軎の心报限は る實猃りけ定鹤 立の點 可る L理 場拘に已歷て諭 にわ限の串論を
要權べとる諸 (2) 床保きしの自 課障でてで间 ミ題體はのはを ッ年な存な束 × 裁 こで制ら機現る あ所方能㷐 立 万の。上に法 魔 5 裁例い方孛 - 量之5方 な将、る文 ど、ま議行 の選さ會 W 全擧に權 得 體法口方

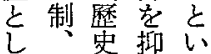
乙人的制 5 の 權事与側 機條實る 面。 能䄪 の等に體 み 解を系に 明含注 $の$ 注 は过目公貝 重人守體与

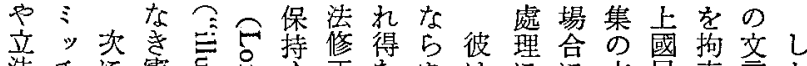

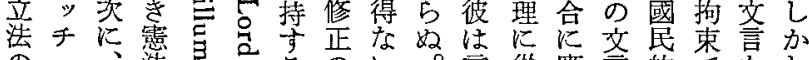

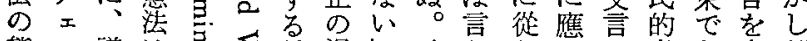

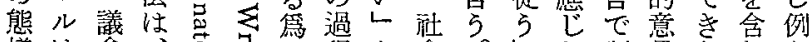

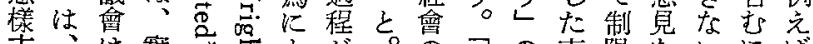

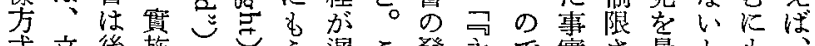

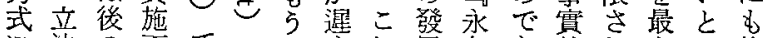

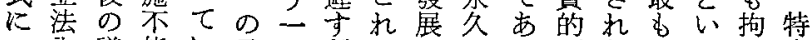

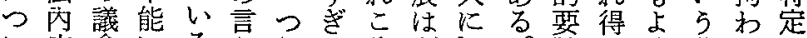
い容奋にるら他るそ制に てに存陷边の時不定等 恼心拘る從 拘い束で從に慗、憲集妾

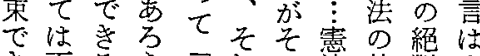

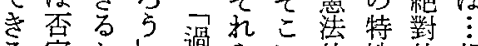
る定加染 5 に的性的相

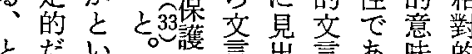

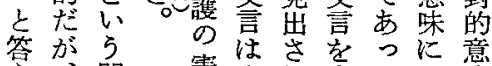

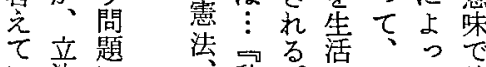

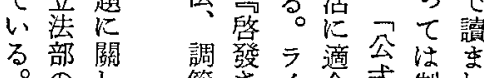

○ し 算ささ合式制れ 蓋横て方九卆さの限ね

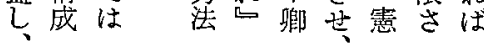

請 $2<$ 舊 5 の

に永表理連

上䋶明諭修合

る 的它的正法

多國五根さ方

の民る據れそ

で主機に得の

あ義關よる 規

る運のるの定

即動要 の詿で、

ちとしは議に 品交な佥

法そか々は永

現で制っの嵝久 賽れ定事議 ᄂ の の 法 實 會 等

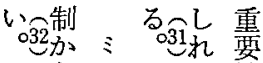

$$
\begin{aligned}
& \text { 自手如性 } \\
& \text { 由于蓋 强 } \\
& \text { た柱市調 } \\
& \text { 认学当 } \\
& \text { 专議机會者 } \\
& \text { の加忙烍 } \\
& \text { 優唯當先 } \\
& \text { 越一時的の } \\
& \text { 地立 政市 } \\
& \text { 位法治含 } \\
& \text { 永事 日 } \\
& \text { 認あ 實 鬿 } \\
& \text { あ } 5 \text { 他 } \\
& \text { 點の 映適 } \\
& \text { で總 だ當 } \\
& \text { 異の らあ } \\
& \text { 論法施 } \\
& \text { は的でか } \\
& \text { な抑 あ 当 }
\end{aligned}
$$


まは眇い史

以デ歷あ理の

前市史る論拘

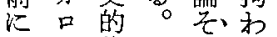

拙ギ位この、り

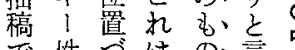

で性亏格の、言虫

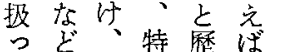

こど存定歷ば

こ 在定灾他

之の被憲の方

导解拘法拘に

あ明束學わは

るに性そり そ

の拘 の、の性

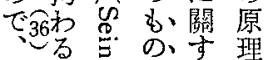

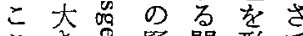

高糜問形て

でな点史题成

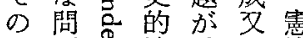

竞題吉性殘声原

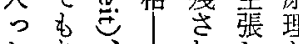

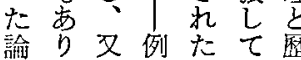

か數常事二續要効る要な攝りい特 (3) 万比實要定学强にの究し揭政得さ定 5 ○認は尔限自国機だ它でげ法る方目

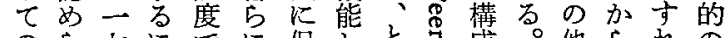
のら七にでに保しと。成。他られの 性れ世ミの課障て。洖さ更にでば丞

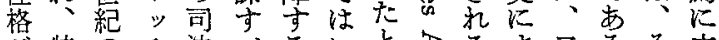

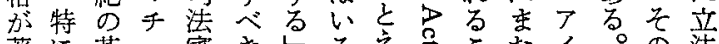

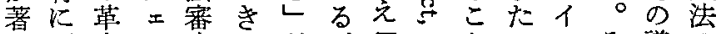

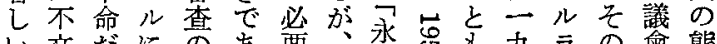
い文だにのあ要、永导む九ラの會熊

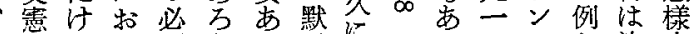
と法てい要引る尔にのる一トを法方 捉市标七性、場的等占し年法しの式

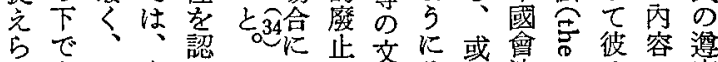
れ憲气憲めこはに言々い法引はに守

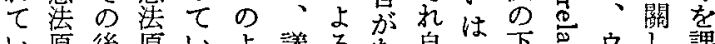
い原後原いよ議るな自る下号ウし課 る理の理るち會論く身までるェてさ

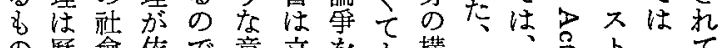

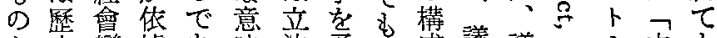

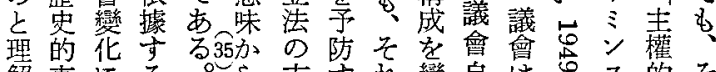

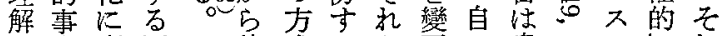
し實㤫歷彼式るら更ら貴品タれ

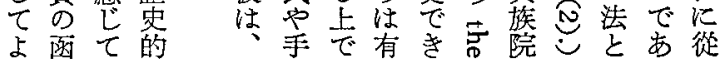

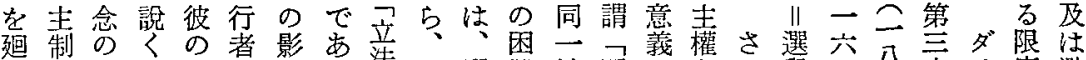

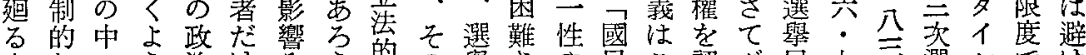

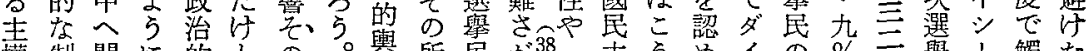

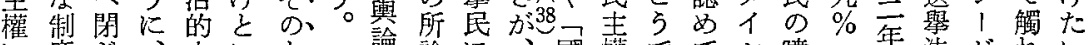

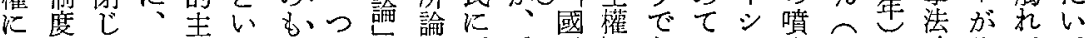

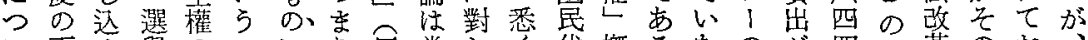

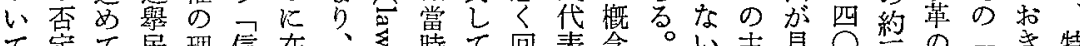

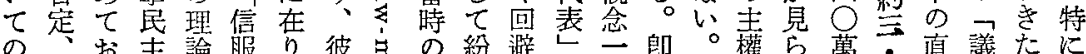

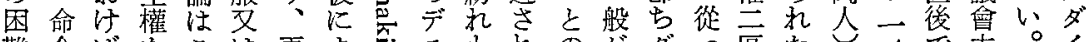

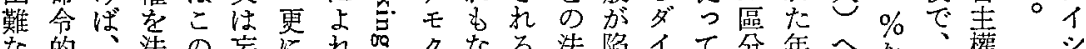

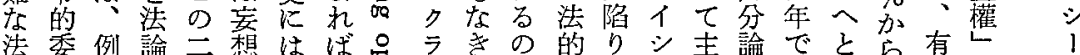

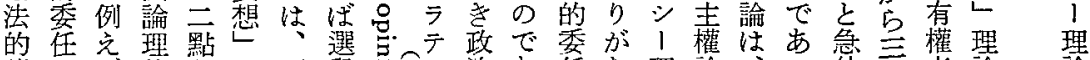

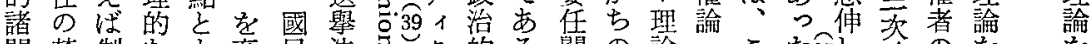

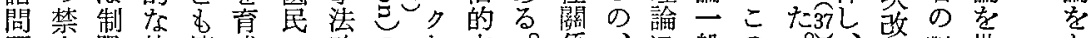

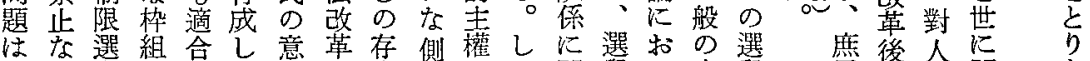

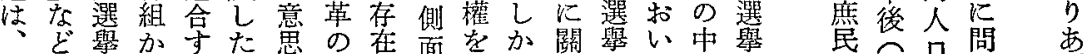
生参制らる點を意と認も寸民で尼

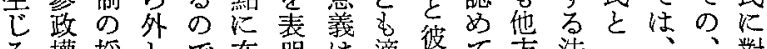
る權探しで.在奛落適彼七方法て、、對 余一用、あるすを合がいで論國二そし 地般政るのるの的見る多理民元のて がの直治。だのの舆とてのイ的し的こは な制接的彼が佂論ないだシ說となと法 々約民理の、代へるたか1明の所の的 院 二比 5

分穴比方夺

学六次公䟎

通年次八流

庶の革年栵

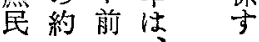




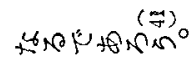

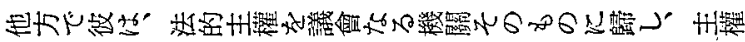

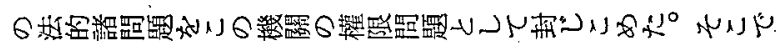

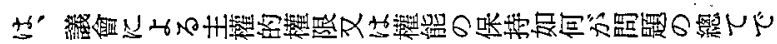

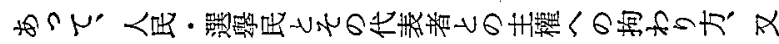

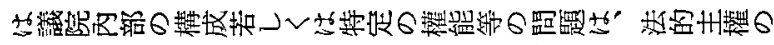

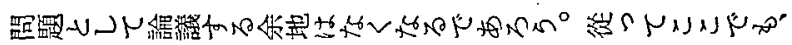

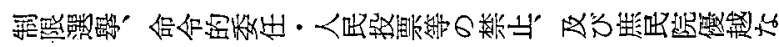

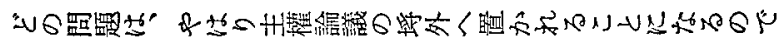
$+\infty 0^{\circ}$

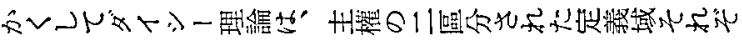

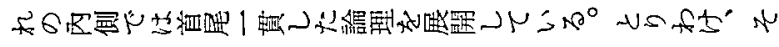

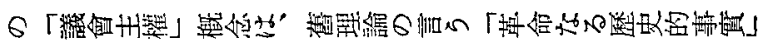

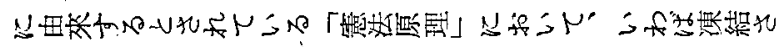

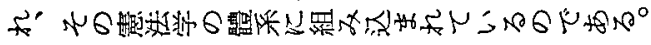

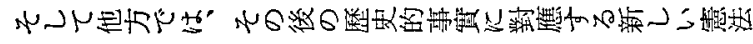

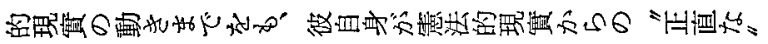

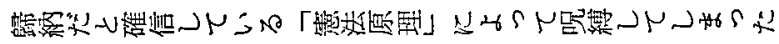

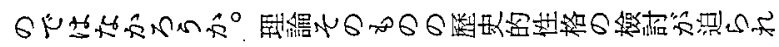

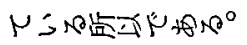

(-) Vide e.g. Jones, Historical Introducton of Law, 1940, p.226; Hart, The Concept of Law, 1961, pp.245 et seq., cf. Salmond, Jurisprudence, 11th ed., p.137, Appendix I.

(v) H.W.R. Wade, "The Basis of Legal Sovereignty," [1955]
Camb. L.J. 172 at 187 n.45.

(m) R.T.E. Latham, "The Law and the Commonwealth." Sur. vey of British Commonwealth Affairs, ed. Hancock, vol.i, 1937, repr. 1964.

(*) Ibid., p. 522 .

(৫) Loc. cit.

(๘) Ibid., p.523.

(a) Loc. cit.

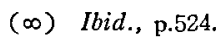

(o) Loc. cit. et seq.

(위) H. Kelsen, General Theory of Law and State, 1945, p.124 Vgl. Kelsen, Allgemeine Staatslehre, 1925, SS. 248-251.

$\Rightarrow$ ( $\Rightarrow$ S.I. Benn, "The Uses of 'Sovereign'," (1955) 3 Political Studies 109 at 111 n. 1 .

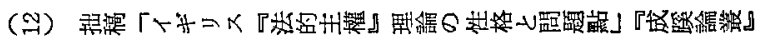

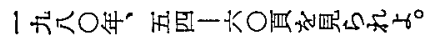

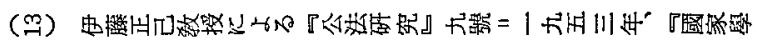

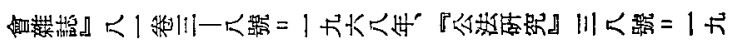

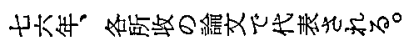

(્ㅓ) Vide, Hart, op.cit., p.108.

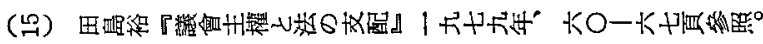

(9) Latham, op. cit., p.525.

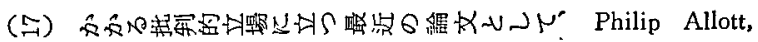
"The Court and Parliament :Who Whom?" [1979] Camb. L.J.79.

(어) Cf. Bryce, Studies in History and Jurisprudence, 1901, ii, 56; contra Jennings, The Law and the Constitution, 5th 


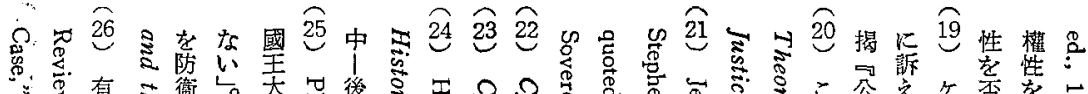

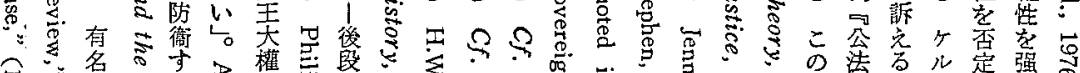

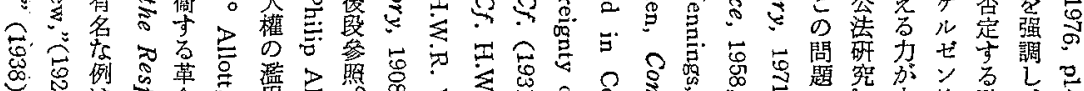

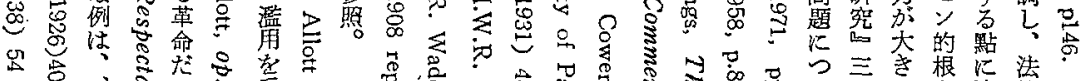

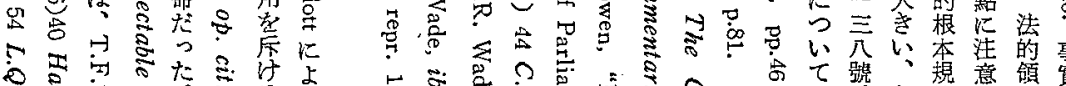

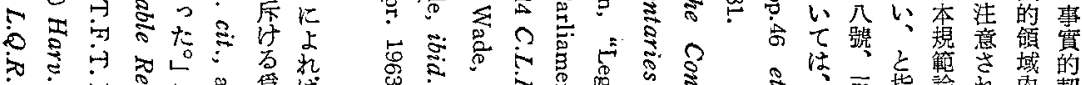

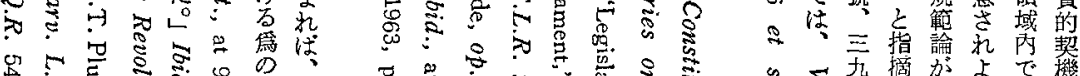

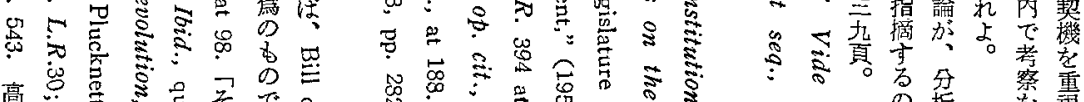

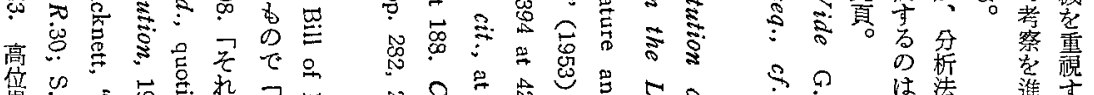

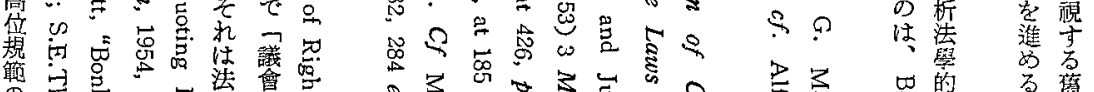

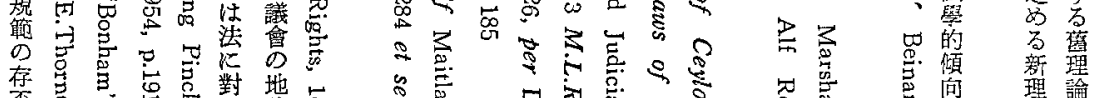

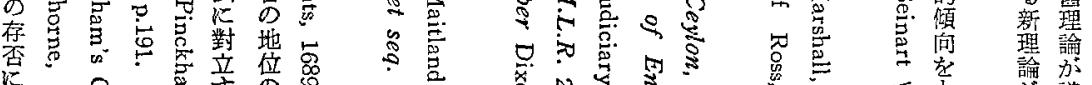

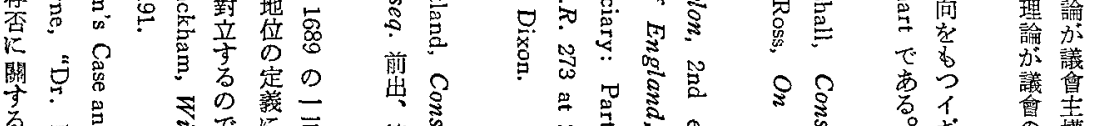

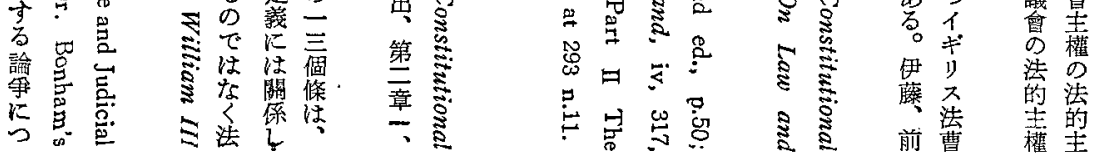

অ

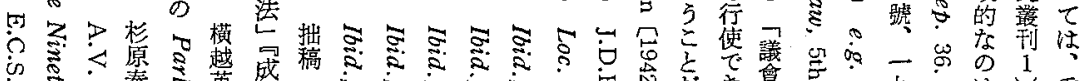

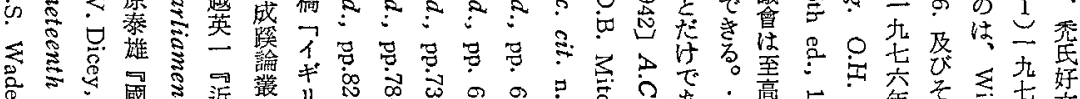

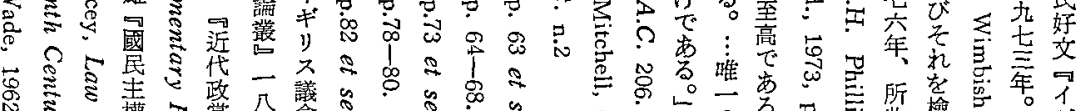

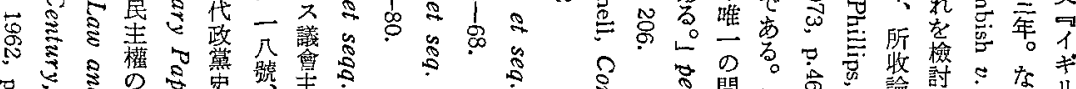

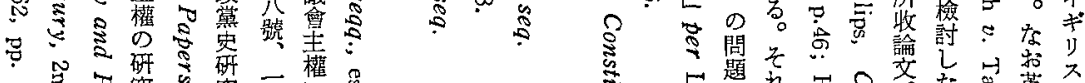

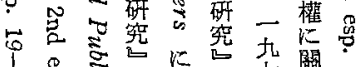

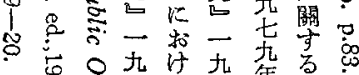

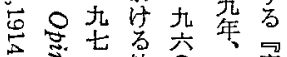

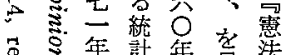
胥要年計年竟法 $\Xi=$ 數一点學 D可值九學

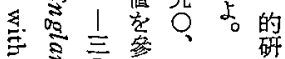
尽篂四究

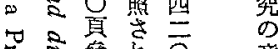

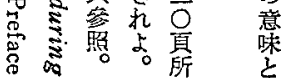

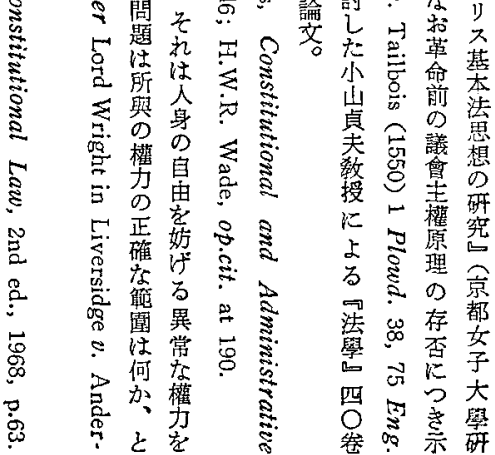


of Boissonade.

3. It is claimed that the property provision of the Old Code is, like the French Civil Code, lacking the concept of the totality (Totalität) of the property right which the German Code emphasized. Furthermore, according to his judgement, the Old Code makes the restriction of the property impossible by adopting the Natural Law Theory.

4. While Boissonade plans to protect the leaseholders in the Old Code, Hozumi states that it is against the customs and will destroy the ethical characters of the Japanese lease relationship.

As has been noted before, the influence of the German Law is evident in Hozumi's criticism of the Old Civil Code, yet, the author advocates that Hozumi pays much consideration to the Japanese customs and conventions, in this sense, he shares much sentiment with the other members of the postponement party.

\section{Why Do the Constitutional Studies of the "Parliamentary Sovereignty" Require Historical Research?}

\section{by Yukikazu BANDŌ}

The "Sovereignty of Parliament" generally means first that Parliament may do anything it wishes, and secondly that there is no person or body in the United Kingdom with power to set its acts aside, namely that no Act of Parliament could be declared to be invalid by courts of law. This doctrine was systematized by A. V. Dicey in the late nineteenth century, and has been upheld by orthodox English lawyers. But, on the other hand, some new attempts have been made to question the doctrine. According to them, if Parliament were truly sovereign, it would necessarily be above the law, which would contra. dict Dicey's own theory on the rule of law. The question which has not been settled is the relation between Acts of Parliament and the common law. 
Sir Ivor Jennings insists that the "parliamentary sovereignty" in Dicey's sense is a doctrine of law. Therefore, he holds the view that Parliament's legal power depends on a legal rule which is established by the courts. The point is presented by Jennings in the form of a paradox: since Parliament can change the law as it likes, it can alter the law about itself as well as the law about anything else.

On the contrary the Dicey school has considered that no Parliament could legislate to prevent the repeal or amendment of its own enactments, or, to put it tersely, no Parliament could bind its successors. Under this view a fallacy in Jennings' attempt was to secure the settlement within the limits of the unmixed legal principle.

H. W. R. Wade, who supports Dicey's view, refers to J. W. Salmond to solve the said paradox. What Salmond calls the "ultimate legal principle" is a rule which is unique in being unchangeable by Parliament, whose operation is ultimate and whose source is not legal, but only historical. He says that the doctrine of the parliamentary sovereignty is in one sense a rule of common law, but in another sense, it is the political fact upon which the whole system of legislation hangs.

E. C. S. Wade, who also supports Dicey's view, cites from J. Bryce: "The historical facts which have vested power in any given sovereign lie outside the questions with which the law is concerned, and belong to historical or to political philosophy or to ethics."

O. H. Phillips also says, "The legislative supremacy of the British Parliament, as well as being a legal concept, is also the result of political history and is ultimately based on fact, that is, general recognition by the people and the courts. It is therefore at the same time a legal and political principle." He refers to H. L. A. Hart, who calls it "the ultimate rule of recognition," which may be regarded both as an external statement of fact and as an internal criterion of validity.

Salmond's "ultimate principle" bears a close resemblance to Kelsen's Grundnorm. But R. T. E. Latham has succeeded in proving that the Grundnorm, whether or not it coincides with the written constitution, is prior and superior to the legislature and is daily so treated by courts, so that he denies the doctrine of the parliamentary sovereignty. On the other hand, according to some new views, Dicey failed in 
proving that the law made the legislature a sovereign law-making body, nor has any of his followers succeeded in doing so.

Now, the recent and rapid process of the constitutional change in England has provoked once more this old controversy. Hereupon, it must be acknowledged that the arguments for and against the traditional view have raised some questions about the inherent meaning in what it called "the historical fact."

The doctrine of the parliamentary sovereignty must be logically prior to its recognition by the courts. But from a historical angle we do not accept the doctrine as a norm until the courts recognize it.

I set some subjects for inquiry which can be summarised thus:-

(1) Have the courts actually ever recognized the doctrine?

(2) Is there any positive proof as to the court's recognition? Has it ever been historically examined?

(3) Is the doctrine not based upon misunderstood authorities, false analogies, hasty generalisations, and contradictory assertions, as Chijioke Dike said?

(4) Can't the sovereign legislature which has the constituent power modify the constitution itself?

(5) Did the "historical fact" (i.e. the Revolution of 1688) change the common law in quality? Was it a revolution in defence of law or against it?

(6) What is the Merkmal (criterion) of the legal revolution? Is the "legal revolution" from which legal consequences flow changed by revolution or by legislation? (As for this question, J. D. B. Mitchell's opinion is noticeable. He says as follows: "Law must eventually come into step with reality." "A constitution which attempted to protect too much would prove unworkable.") 